UC-NRLF

COOPER ORNITHOLOGICAL CLUB

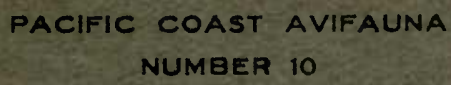

\title{
A DISTRIBUTIONAL LIST OF THE BIRDS OF ARIZONA
}

BY

HARRY S. SWARTH

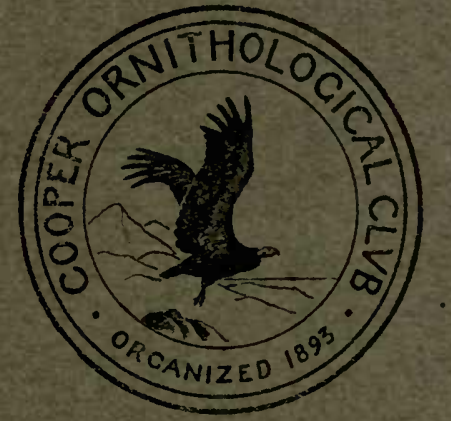

HOLLYWOOD, GALIFORNIA

PUBLISHED BY THE GLUA

May 25, 1914 

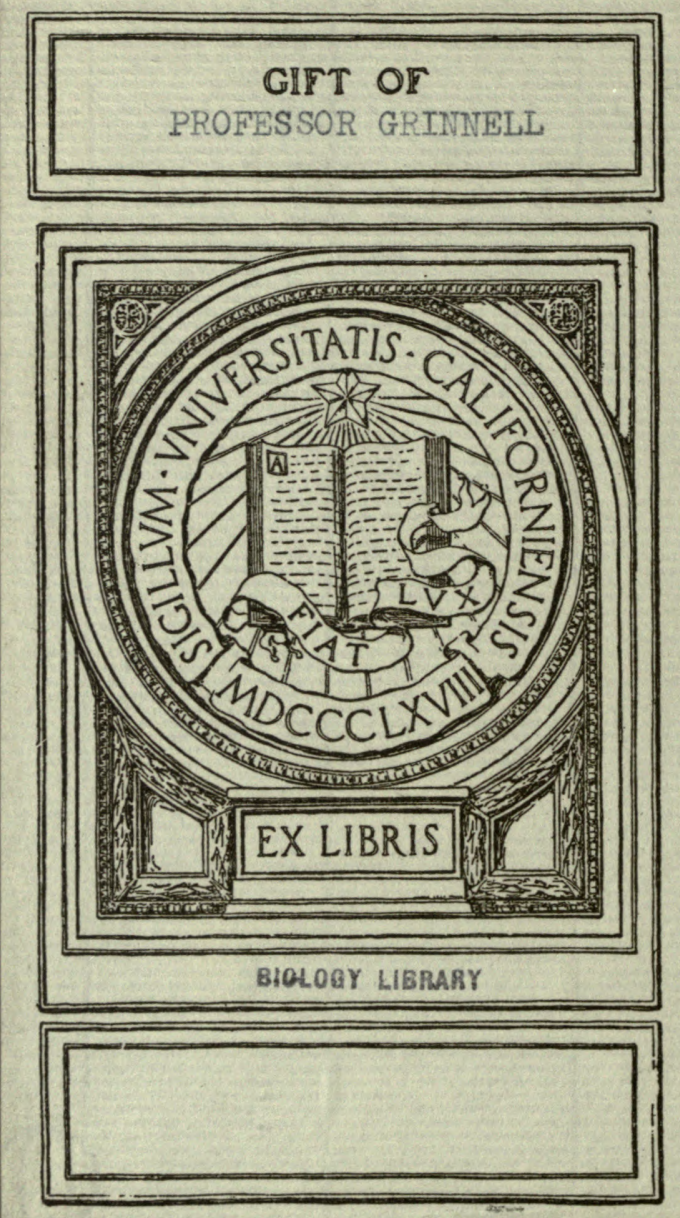


COOPER ORNITHOLOGICAL CLUB

\author{
PACIFIC COAST AVIFAUNA \\ NUMBER 10
}

\title{
A DISTRIBUTIONAL LIST OF THE \\ BIRDS OF ARIZONA
}

BY

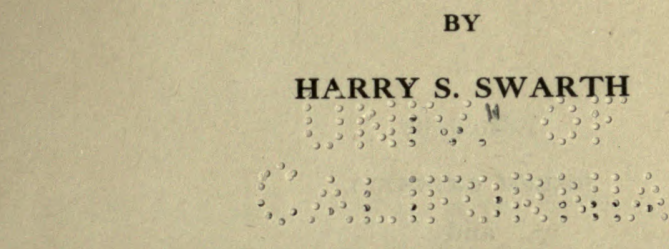

CONTRIBUTION FROM THE MUSEUM OF VERTEBRATE ZOOLOGY OF THE UNIVERSITY OF CALIFORNIA

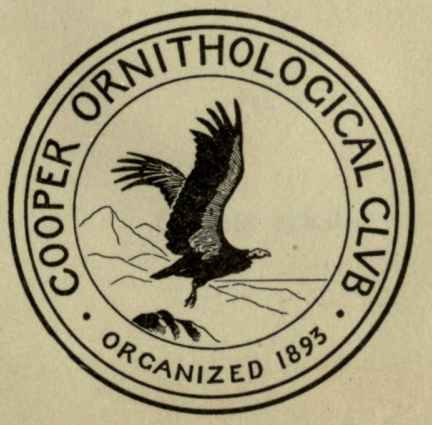

HOLLYWOOD, CALIFORNIA

Published by THE Club

May 25, 1914 


$$
\begin{aligned}
& \text { A } 6684 \\
& \text { A } 6583 \\
& \text { BIOLOGY } \\
& \text { LIBRARY }
\end{aligned}
$$

$\because \because$ Edited

$\therefore:$ 9อSFPH: YRINNFL $\therefore$

HARRY S. SWARTH

at the

Museum of Vertebrate Zoology;

University of California

Professor Grinnell

Moceer LiBRaRY 


\section{NOTE}

Pacific Coast Avifauna No. io is the tenth in a series of publications issued by the Cooper Ornithological Club for the accommodation of papers whose length prohibits their appearance in THE CONDOR.

The publications of the Cooper Ornithological Club consist of two seriesThe Condor, which is the bi-monthly official organ, and the PACIFIC CoAst AviFAUNA.

For information as to either of the above series, address one of the Club Business Managers, J. Eugene Law, Hollywood, California, or W. Lee Chambers, Eagle Rock, California. 


\section{CONTENTS}

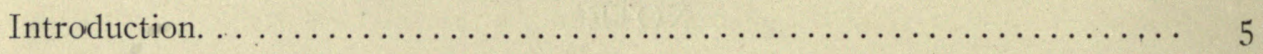

Acknowledgments. . . . . . . . . . . . . . .

Distributional List of the Birds of Arizona ................. 9

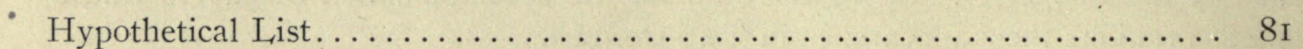

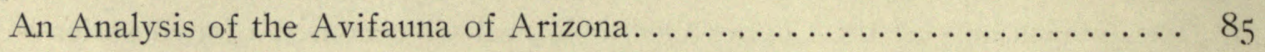

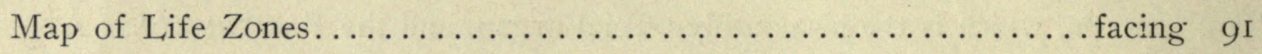

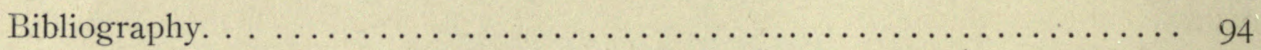

Index. . . . . . . . . . . . . . 


\section{INTRODUCTION}

The beginning of this list of the birds of Arizona dates back about eleven years, to a time when the author was engaged in field work in that state. A hasty compilation was made of a few local lists, and the manuscript carried in the field as a guide and aid in making observations and collections. This beginning proved an incentive to the gathering of further data, and shortly after, the opportunity presenting itself for visiting more extensive libraries than had hitherto been available, a careful and systematic search was made through the literature dealing with the ornithology of Arizona. The resulting information was filed away and added to as chance offered, but more pressing work and other interests interfered to prevent the whole from being put into shape for publication. Furthermore it soon became evident that while a fairly long list of species could be compiled as occurring within the state, the published information concerning a large proportion of them was scanty and fragmentary. The writer had hoped to be in a position to continue field work in certain little known sections of the state, where undoubtedly there is much to be added to our knowledge of the birds, but this contingency became more and more improbable, and under the circumstances it seemed advisable to publish the list as it now stands.

It is hoped that as far as it goes this list will be found to be fairly accurate. Pertinent literature has been gone over with care, and it is doubtful if any important publication has been overlooked. At the same time it can hardly be doubted but that there are in collections specimens whose existence will modify many of the statements made here, and it is also highly probable that there are active collectors who have many unpublished records in their notes which would also occasion changes. Available collections and collectors' notes, however, have been made use of wherever possible.

The aim of the present publication is to give a list of the species of birds occurring in Arizona, with a synonymy of the names applied, as regards their occurrence within the state, and a brief but comprehensive outline of the manner of occurrence. The latter, it is hoped, is in each case as clear and accurate as the present state of our knowledge permits. An effort has been made to give a general statement outlining the range and manner of occurrence, supplemented by the citation of anthorities for extreme or unusual instances. Exact dates have been given only for the rarest species, those of which but a few specimens have been recorded. The synonymy consists of those names by which the species has been known in literature pertaining to Arizona ornithology.

Thus the general manner of treatment is closely similar to that followed by Grinnell in his Check-List of California Birds, * the main difference lying in the greater elaboration of detail in the outlining of ranges, and the numerous citations of authorities, in the present publication.

The order, and in general the nomenclature, of the American Ornithologists' Union Check-l,ist, has been follower. Wherc there is disagreement from this

* Grinnell, J., Check-I, ist of California Birds. Pacific Coast Avifauna, no. 3, 1902, pp. 1-92, 2 pls. 
standard it is usually in cases where the autluor's personal experience leads him to a different view; but there are one or two instances (such as with the group of I:nncos) where the conclusions of some specialist, at variance with the Check-Lisl, are so closely in accord with observations of the author's (in themselves perhaps insufficient to warrant outspolien disagreement), that this worker's treatment of the group is accepted in its entirety.

The expedition conducted by the California Nuseum of Vertebrate Zoology down the Colorado River from Needles to Yuma in the early spring of IgIo, furnished much valuable information in regard to the manner of occurrence of many species of birds. An apparent inconsistency may be noticed in the citations of certain of these records, inasmuch as some of them pertaining to occurrences on the California side of the river have been quoted. Winere this is done, however, it is in the case of species which are known to occur in Arizona, but where there is lack of data defining their status in this valley. In such a case, the record, though strictly speaking not pertaining to Arizona, has a very definite value in defining the status of an Arizona bird, and its use seems to be justified.

The appended bibliography contains the titles of such publications as have been consulted by the author in connection with the present contribution, the criterion for the admission of a title being that the work relate definitely to the ornithology of Arizona. Books of a general nature are not included unless they contain some definite, first-hand information on the subject, something not previously published. It is hardly to be hoperl, of course, that nothing has been overlooked, and it is to be expected that additional titles relevant to the subject are still to be found, but it seems unlikely that any such will be of a nature to seriously modify many of the statements made in the following pages.

The author's personal field work in the state has been almost altogether in the region lying between the Gila River and the Mexican boundary line. Trips of varying lengths, during four different years and covering every month except December and January, included parts of this region in great cietail, and larger portions in a more sulperficial manner. Of the three hundred and sixty-two species and sub-species here credited to the state, two hundred and twenty-seven were personally observed. In most cases specimens were collected.

The accompanying map showing life zones of the state is presented with full realization that it is probably open to criticism in many particulars, and will cor:espondingly doubtless require revision in many of the details. At the same time it is believed that it will be of sufficient aid in illustration of the distribution of many species, and in showing the salient zonal peculiarities of the state, to fully justify its publication, even in its admittedly tentative form. This map is compiled from various sources. The northeastern corner is copied from Merriams (1890) zone map of the San Francisco Mountain region; the zones of much of the central portion of the state are computed from descriptions of localities in publications of Coues (1866), Henshaw (1875), Scott (1886), Mearns (1890), and others. Maps showing the distribution in Arizona of certain conspicuous forest trees useful as zone indicators, loaned to the author by the District Forester's office, Albuquerque, New Mexico, were also used, and found of great assistance. Much of the region soutl of the Gila River has been mapped from personal observations of the author. 


\section{ACKNOWLEDGMEN'TS}

In going through literature dealing with the subject it became apparent that many of the older government reports, and some more modern works as well, contained, among much trustworthy and valuable information, statements rtgarding certain species which needed corroborative proof other than that to be found on the printed page. This was a phase of the problem utterly beyond the author's power to deal with, unaided, and he is correspondingly grateful to $\mathrm{Mr}$. W. W. Cooke of the Biological Survey, for cordial assistance in supplying definite information regarding many of these doubtful cases. Further acknowledgment is made in the following pages in each of the rather numerous instances in which his aid was invoked.

To Professor C. B. Cory and Mr. W. H. Osgood, of the Field Museim of Natural History, obligations are acknowledged for permission to print hitherto unpublished data regarding certain specimens in the ornithological collection of that institution. To Mr. F. C. Baker, of the Chicago Academy of Sciences, the author expresses his gratitude for the free use of the library of the academy accorded him, as well as for assistance and advice in the purstit of the bibliographical portion of the work.

To Mr. G. Frean Morcom grateful thanks are extended for his generous support of, and deep interest in, field work which otherwise could hardly have been 11ndertaken. From Mr. F. S. Daggett, now Director of the Los Angeles Museun of History, Science, and Art, the author received advice and encouragemeit on many occasions. Mr. Daggett added to his own collection large series of birds collected at certain localities in Arizona which the author had been unable to visit, or which were taken at different seasons of the year from the time of the author's work in the region, and the information gained thereby was freely placed at his disposal.

Mr. F. C. Willard, of Tombstone, Arizona, obligingly read the manuscript of this list, with a view of adding thereto such unpublished records of his own, obtained during a number of years of careful observation of the birds of southeastern Arizona, as would add to the statements made by the author. The valuable information thus secured is cited in the text as "F. C. Willard. MS".

Mr. A. B. Recknagel, Assistant District Forester, Albuquerque, New Mexico, very kindly loaned the author blue print maps which were on file in nis office, illustrating the distribution in Arizona of seven conspicuous species of forest trees, useful as zone indicators. The data thus obtained, of the greatest value in compiling a map of the life zones of Arizona, could have been secured in no other way, and the author is deeply appreciative of the courtesy extended him.

Finally, grateful appreciation is hereby expressed for the co-operation of Mr. Joseph Grinnell, whose assistance and advice have materially aided in the completion of this list, and whose helpful suggestions throughout the course of the undertaking have strongly influenced the author, both in regard to matters of form and methods of work.

H. S. SIVAR'TH. 



\section{DISTRIBUTIONAL, LIST OF THE BIRDS OF ARIZONA}

I.

\section{Aechmophorus occidentalis (Lawrence).}

WESTERN GREBE.

Synonym-Podiccps occidentalis.

Status-But two published records of its occurrence in Arizona. Inenshaw ( $1875 \mathrm{~b}$, p. 488) secured a specimen on the Gila River in November; and Brown ( 1903, p. 50) reported it as a permanent resident in the vicinity of Y :ma. There is, however, no evidence of its breeding there, or anywhere else in the state.

2.

\section{Colymbus nigricollis californicus (Heermann).}

\section{AMERICAN EARED GREBE.}

Synonyms-Podiceps californicus; Podiceps auritus californicus.

Status-This species was found breeding by Mearns (I890a, p. 50) in the high plateau region north of the Mogollon Mountains-Stoneman s Lake, Mormon Lake, and near Flagstaff. It has also been recorded from the Colorado River at Mohave, and from Moencopie, in northern Arizona, in Sertember.

3 .

\section{Podilymbus podiceps (Linnaetıs).}

\section{PIED-BILI.ED GRËBE.}

Synonyin-I’ndil!'mbus carolinensis.

Status - Apparently fairly common on the Colorado River during the migrations and in winter, while it is of only casual occurrence elsewhere. There are no definite breeding records for the state, though Brown (Igo3, p. 49) speaks of it as a resident in the vicinity of Yuma.

4.

\section{Gavia immer (Brünnich).}

\section{COMMON LOON.}

Synonym-Colymbus torquatus.

Status-According to Coues (I866a, p. I00) a common winter visitant on the Colorado River. There is in the Museum of Vertebrate Zoology an adult female (no. 6403) taken (probably by W. W. Holder) at "Mineral City on the Colorado. River" (=Ehrenberg), April 4, I864.

5 .

Gavia stellata (Pontopiddan).

RED-THROATED LOON.

Synonym-Urinator lumme.

Status-There is but one record for the state, that of an immature male secured by Brown on the Papago Indian reservation, near Tucson, December 20, I 884 (Scott, I886, p. 383 ). 6.

\section{Larus delawarensis Ord.}

Ring-Billeid Gull.

Status-Seen by Cotres (I866a, p. 99) on the Colorado River "in the autumi of I865." The only recent record known to me is that of Price (1899, p. 90). who doubtfully identified as of this species two small gulls seen near Yuma. November 27,1898 . 
BONAPARTE, GULl.

Synonym-Chroicocephalus philadelphia.

Status-Dr. Cones met with this species on the Gila River (1865b, p. 538). and on the Colorado River, between Forts Mohave and Yuma, in September, I865 (1866c, p. 259), but it has not been observed in the region by any one since that time.

8.

\section{Sterna forsteri Nuttall.}

FORS'TER TERN.

Status-There is in the Museum of Vertebrate Zoology an adult male (no. I 26I6) taken May 4, I9IO, at the mouth of the Gila River, the first definite record for Arizona. 'The species was included in Cones' ( $1866 a$, p. 99) list of birds occurring on the Colorado River, but with no statement as to the time or manner of its occurrence.

9.

Sterna hirundo Linnaeus.

COMMON TERN.

Status-There is, apparently, record of but a single specimen of this species from Arizona, one secured by Henshaw (1875b, p. 486) on the San Pedro River, September 3, I872.

IO.

Hydrochelidon nigra surinamensis (Gmelin).

BLACK TERN.

Synonyms-Hydrochelidon fissipes; Hydrochelidon lariformis; Hydrochelidon nigra; Hydrochelidon surinamensis.

Status-A rare migrant. Henshaw secured it in southern Arizona in the fall (see Henshaw, I875b, p. 487 ; Saunders, I896, p. 20), and Brewster (1883. p. $3^{6)}$ has recorded one taken at Cienega Station, April i 7.

II.

Phaëthon aethereus Linnaeus.

RED-BILLED TROPIC-BIRD.

Synonym-Phaëthon americanus.

Status-One specimen taken by Breninger at Phoenix, April 10, 1905. This bird is now in the collection of the American Muscum of Natural History (ct. Miller, 1910, p. 450).

12.

Anhinga anhinga (Linnaeus).

ANHINGA.

Status-Herbert Brown met with this species near Yuma, during the winter of $1905-06$, when it appeared to be not uncommon. He also reports a single specimen, a female, killed on the Santa Cruz River, near Tucson, September I2, I893 (rgo6, p. 2I7). These are the only records for the state. 
I 3 .

\section{Phalacrocorax auritus albociliatus Ridgway.}

Farallon Cormorant.

Synonym-Graculus dilophus.

Status-Mentioned by Cones (1866a, p. IOO) as occurring on the lower Colorado River. Seen at various points along the river between Laguna Dan and Yuma, in April and May, I910 (Mus. Vert. Zool.).

14.

\section{Pelecanus erythrorhynchos Gmelin.}

American White Pelican.

Synonym-Pelecanus trachyrhynchus.

Status-The numerous records would indicate this species to be of common uccurrence on the Colorado River, and on the lower Gila River, at all times of the year except midsummer. Except for one record from Tucson (Sloanaker, I913, p. I95), it has apparently not been seen elsewhere in Arizona. I 5 .

\section{Mergus americanus Cassin.}

American Merganser.

Synonym-Merganser americanus.

Status-Mearns (1890a, p. 50) speaks of this species as breeding in the Mogollon Mountains, in the streams tributary to the Salt and Verde rivers, and also at Fort Verde. Scott (1886, p. 384) found it rare on the San Pedro River in January.

I6.

\section{Mergus serrator Linnaeus.}

RED-BREASTED MERGANSER.

Synonym-Merganser scrrator.

Status-Merriam observed a few individuals at the bend of the Colorado, and at the mouth of Beaverdam Creek, northwestern Arizona, in May, I89I (Fisher, I893b, p. 15). This is the only published record of the occurrence of the species in Arizona. Observed on the Colorado River, near Needles, February 18, and at Chemehuevis Valley, March 8, 1910 (Mus. Vert. Zool.). Two were shot by F. N. Wolcott from a flock of four, near Fairbanks, April 8, I9I I (F. C. Willard, MS).

17.

Lophodytes cucullatus (Linnaeus).

HOODED MFiRganser.

Status-Known only from the record by Cones (1868, p. 84) of its occurrence at Camp Grant; and by Scott (I886, p. 384) of an immature female in the collection of Herbert Brown, taken near Tucson, December 5, 1885. A lone birrl was shot by F. N. Wolcott on the San Pedro River in the fall of 1896 (F. C. Willard, MS).

18.

Anas platyrhynchos Linnaeus.

MALLARD.

Synonym-Anas boschas.

Status-A common winter visitant in suitable localities in southern Arizona, usually along the larger streams. Mearns found it in the Mogollon Mountains in May and June, so it probably breeds, though in limited numbers, in places where conditions are favorable. 
I9.

\section{Chaulelasmus streperus (Linnaens).}

Gadwall.

Synonym-Anas strepera.

Status-Mearns found this species in summer in the Mogollon Mountains, where it was common and "probably breeding". Coues (1866a, p. 99) met with it on the Colorado River in October, and Scott (1886, p. 384) took a specimen at Tucson in December.

20.

Mareca americana (Gmelin).

BALDPATE.

Synonyms-Anas americana; Anas penclope.

Status-A common migrant, and, in sonthern Arizona, a winter visitant. Reported by Mearns (I890a, p. 50) as occurring in summer at Mormon Lake, in the Mogollon Mountains, where he supposed it was breeding, though no nests were found.

$2 \mathrm{I}$.

\section{Nettion earolinense (Gmelin).}

GRERN-WINGED TEAL.

Synonyums-Querquedula carolinensis; Anas carolinensis.

Statı1s-A common migrant, reported fron various scattered localities. K'smains through the winter in southern Arizona: San Pedro River, Colorado River, 'Tucson, etc.

22.

\section{Querquedula discors (Linnaeus).}

\section{BLUE-WINGED TEAL.}

Synonym--Anás disiors.

Status-Has been reported from various parts of Arizona. Scott speaks of it as being of occasional occurrence in winter in the vicinity of Tucson, while Mearns (1890a, p. 51) found the species in May and June on the lakes of the Mogollon Mountains, where it may have been breeding. There are also records of individuals taken during the migrations at lucson, Ehrenberg (Colorado River), Sulphur Spring (Cochise County), and San Francisco Mountain. Not infrequently taken in winter on the San Pedro River (F. C. Willard, MS).

23.

\section{Querquedula cyanoptera (Vieillot).}

\section{Cinnamon Teal.}

Synonyms-Pterocyanca caeruleata; Anas cyanoptera.

Status-A common migrant thronghout the state. Has been found breeding in the Mogollon Mountains, and is reported as a winter visitant in extreme southern Arizona (Tucson, Sulphur Spring, etc.).

24.

\section{Spatula clypeata (L,innaeus).}

SHOVELLER.

Status-A migrant, and, in southern Arizona, a winter visitant. Mearns ( $1890 a$, p. $5 \mathrm{I}$ ) found the species in May and June on the lakes in the Mogollon Mountains, where it may have been breeding. 
25.

Dafila acuta (Linnaeus).

Pintail.

Status-Has been reported as a migrant from various parts of the state. It was found on Mormon Lake, in the Mogollon Mountains, in May, by Mearns. Seen on the San. Pedro River in February, so is probably a winter visitant in sonthern Arizona (Willard, I9Ioc, p. Iro).

26.

\section{Marila americana (Eyton).}

REDHEAD.

Synonym-Ay'thya antericana.

Status-The only record of the occurrence of this species in Arizona is that by Scott (I886, p. 384), who reported it as occurring in winter in the vicinity of Tucson and on the San Pedro River.

27.

Marila valisineria (IVilson).

Canvas-Back.

Synonym-Aythy'a vallisneria.

Status-Scott ( 1886, p. 384) records a small flock seen on the San Pedro River, January 28, I886, while Coues ( $1892 \mathrm{a}$, p. I98) reports it as occurring in large numbers on the Verde River near Fort Whipple, in winter. These are the only records for the state.

28.

\section{Marila marila (Linnaeus).}

Grenter Scaup Duck.

Synonym-Aythya marila nearctica.

Status-Known only from the record by Scott (I886, p. 384), who speaks of it as "rather common on the San Pedro in winter."

29.

Marila affinis (Eyton).

LESSER SCAUP Duck.

Synonym-Aythya affinis.

Status-A record by Scott ( 1886, p. 384) of "a few seen on the San Pedro during late January." Common near Tucson in March, I9I2 (Sloanaker, I9I3, p. 195). Observed on the Colorado River, near Ehrenberg, March 24, and at Cibola, April 4, 19ло (Mus. Vert. Zool.).

30.

Clangula clangula americana Bonaparte.

AMERICAN GOLDEN-EYE.

Status-Only one record, that of two specimens taken near Tucson, April I and February I, respectively (Sloanaker, 1912, p. I54).

3 I.

Charitonetta albeola (Linnaeus).

\section{BUFFLE-HEAD.}

Synonyms-Clangula albcola; Bucephala albeola.

Status-While apparently not common, this species has been reported in winter from various scattered localities in all parts of the state (Tucson, San Pedro River, Bill Williams River, etc.). 
Synonym-Erismatura rubida.

Status-Though there are curiously few published records of the occurrence of this species, it is, nevertheless, a fairly common migrant. Mearns met with it in summer in the Mogollon Mountains (Stoneman's Lake, Mormon Lake), and near Flagstaff, where they were preparing to breed. It very probably remains through the winter in southern Arizona, though there are no records of its doing so. Observed near Tucson in April, 1896 (Swarth MS), and on the Colorado River, near Laguna Dam, April 23, I910 (Mus. Vert. Zool.).

33 .

Chen hyperboreus hyperboreus (Pallas).

\section{LESSER SNOW GoOSE.}

Synonym-Anser hyperboreus.

Status-There is a record by Coues (1866a, p. 98) of "specimens taken near Fort Whipple, Oct. 17, 1864." Seen on the Colorado River, near Needles, Feh. ruary I6 and 23, I9Io (Mus. Vert. Zool.).

\section{WHITE-FRONTED GOOSF.}

Synonyms-Anser albifrons; Anser gambeli.

Status-Coues (1866a, p. 98) found it abundant on the Colorado River. There is no published statement of its occurrence in the region since that time.

\section{Branta canadensis canadensis (Linnaeus).}

\section{Canada Goose.}

Synonym-Bernicla canadensis.

Status-The species has been reported both from the Colorado River, and from the San Pedro River, in winter, but from the paucity of records it would seem to be of uncommon occurrence.

\section{Branta canadensis hutchinsi (Richardson).}

\section{HuTchins Goose.}

Synonym-Bernicla hutchinsi.

Status-The only records for Arizona are those by Coues of its occurrence on the Colorado River ( $1866 \mathrm{a}$, p. 98), and at Fort Grant (1868, p. 84).

\section{BLACK-BELLIED TREE-DUCK.}

Status-Herbert Brown (I906, p. 2I7) has reported the killing of six specimens of this duck, out of a flock of eight, on the Santa Cruz River, near Tucson, on May 5, r899. This is the only Arizona record. 
38.

Dendrocygna bicolor (Vieillot).

Fulvous TreE-Duck.

Synonym-Dendrocygna fulva.

Status-Coues (1866a, p. 98) has recorded the capture of " a pair taken in November, about twenty miles from Fort Whipple." From a published note of Brown (1906, p. 217) it would seem to be of fairly common occurrence in winter on the Colorado and Gila rivers, in the vicinity of Yuma, and decidedly rare elsewhere in the state.

39.

\section{Olor columbianus (Ord).}

Whistling Swix.

Synonym-Cygnus americanus.

Status-Recorded by Coues ( 1866a, p. 98) from the Colorado River and Fort Mohave. There is a recent instance of its occurrence at Sacaton, Pinal ('ounty, November 2I, I9ro (Gilman, I9r ra, p. 35).

40.

Plegadis guarauna (Linnaetis).

WhITE-FACED GLOSSY IBIS.

Synonyms-Ibis ordii; Falcincllus ordii; Ibis guarauna; Ibis thalassinus: Plegadis autumnalis.

Status-Apparently fairly abundant, as there are records of its occurrence during the migration in various parts of the state: Tucson, Little Colorado River, Forts Whipple and Apache, and at various points along the Gila and Colorado rivers. It has been reported as breeding at Mormon Lake, in the Mogollon Mountains (Merriam, 1890, p. 88). Has been found at Tombstone in winter (Cooke, I9I3, p. 2I).

$4^{\mathrm{I}}$.

\section{Mycteria americana Linnaeus}

Wood IBIs.

Synonym-Tantalus loculator.

Status-Apparently common, during the summer months, from May to September, along the Colorado River, at least as far up as Fort Mohave (Coues, 1866a, p. 96). There are also records for the various tributaries of that stream: the Gila, San Pedro, Bill Williams, etc. It is not known to breed in Arizona, nor has it been observed in winter.

42.

Botaurus lentiginosus (Montagu).

AMERICAN BITTERN.

Synonym-Botaurus minor.

Status-The only breeding record is that of Mearns (I8goa, p. $5^{1}$ ) whr) found the species nesting commonly in the Mogollon Mountains (Mormon Lake, etc.). It is a fairly common migrant elsewhere and has been found in winter on the San Pedro River in southern Arizona (Scott, I886, p. 385). 
43.

Ixobrychus exilis (Gmelin).

LEAST BITTERR.

Synonym-Ardetta exilis.

Status-Cones ( 1866 a, p. 263) noted this species along the Colorado River between Forts Yuma and Mohave, in September, 1865 . This is the only record for the state.

44.

\section{Ardea herodias treganzai Court.}

Pallid Great Blue Heiron.

Synonym-Ardea herodias.

Status-Breeds along the Colorado River, and in southern Arizona, along the Gila River and its tributaries (Mineral Creek, San Pedro River, etc.). Found also in winter in the same region. There appear to be no records whatever from the plateau region of northern Arizona.

45 .

Herodias egretta (Cimelin).

AMERICAN EGRE'.

Synonyms-Ardea egretta; Herodias alba egretta.

Status-Probably a migrant only; there are records of its occurrence in April, May, and Sentember, at varions points on the Colorado, Gila, and San Yedro rivers.

46.

\section{Egretta candidissima candidissima (Gmelin).}

SNOWY IERRN.

Synonyms-Garretta candidissima; Ardea candidissima.

Status-There are but two instances of the occurrence of this species in Arizona: Cottes (1866a, p. 263) observed it on the Colorado River between Forts Mohave and Yuma in September, and Scott ( 1886, p. 385 ) reports a flock of five seen, one of which was secured, near Tucson, in May.

47.

\section{Butorides virescens anthonyi (Mearns).}

Anthony GreEN Heron.

Synonyms-Butorides virescens; Ardea virescens; Ardea virescens anthonyi.

Status-The breeding range of this species appears to be about the same as that of the Great Blue Heron-along the Colorado River, the Gila River, and the tributaries of the latter, north to the Big Sandy and Fort Verde (Oberholser, I9I2, p. 543); while it is reported in winter from the lower Colorado near Yuma, November or Decenber, I898 (Price, I899, p. 9I). Thus far it has not beeı found in the northern plateau region.

48.

Nycticorax nycticorax naevius (Boddaert).

Black-CROWNED Nigh'T HirRon.

Synonyms-Nyctiardea gardeni; Nyctiardea grisea naevia.

Status-A common migrant, occurring in stitable localities throughout the region. Remains through the winter along the lower Colorado River, and probably in the warmer valleys of southern Arizona in general. Said to be a permanent resident in the Vercle Valley (Mearns, I890a, p. $5 \mathrm{I}$ ). 
49.

Grus canadensis (Linnaeus).

LitTtle Brown Crane.

Synonym-Grus mexicana, part?

Status-There are several records of the occurrence of this species at varions points along the Colorado River as well as in the interior, during the migrations and in winter. Some, at least, of these probably refer to G. mexicana, but in the absence of specimens it is impossible to separate them. A late record, authenticated by specimens, is of two birds taken near Tucson (Sloanaker, I9I2, p. I54).

5 .

Grus mexicana (Müller).

Sandhill Crane.

Synonym-Grus canadensis, part?

Status-"A few pairs breed at Mormon Lake, where a Mormon settler took its eggs in 1886" (Mearns, I890a, p. 5I). This record for the Mogollon Mountains appears to be the only definite one for the state. A few are reported as seen along the San Pedro River each winter (F. C. Willard, MS).

5 I.

Rallus levipes Bangs.

LIGHT-FOOTED RAIL.

Status-"Accidental in Arizona" (A. O. U. Check-List, 1910, p. I02). According to information received by me from $\mathrm{Mr}$. W. W. Cooke this record was based on a specimen taken August 25, 1902, by Mr. Herbert Brown, at Yuma.

52.

Rallus virginianus Linnaeus.

Virginia RAIL.

Status-The only Arizona records of the Virginia Rail are of a single bird seen on the San Pedro River, January 28, 1886, by Scott (1886, p. 385), and of one taken at T'ucson, April I I, I886, by Brown (Allen, I886, p. 386, footnote). It should prove to be common, however, if sought for in suitable localities.

Porzana carolina (Linnaeus).

SORA.

Status-Mearns ( $1890 a$, p. $5 \mathrm{I}$ ) found this species in the Mogollon Mountains (Mormon Lake, Stoneman's Lake) in May, abundant and probably breeding. Aside from this it has been found in Arizona on but a few occasions, during the migrations and in seattered localities (Colorado River, Camp Apache, Tucson, Moencopie).

54.

Coturnicops noveboracensis (Gmelin).

YiLLOW RAIL.

Status-One specimen reported from Sacaton, March 28, 1909 (Gilman, I910, p. 46). Not otherwise observed in Arizona.

55 .

Ionornis martinicus (Linnaeus).

Purple Galitinule.

Status-Two specimens have been sccured in Arizona: one on the Santa Cruz. River, near Tucson, October 20, I887 (Brow11, 1888a, p. 109), the other at Tombstone, taken in June, 1904 (Willard, I905, p. II2). 
Florida Gat.linule.

Status-This species is probably fairly common, at least during the migrations, though there are but very few published statements in regard to its occur.rence. Scott (1886, p. 386) found it on the San Pedro River in January, and quotes Brown to the effect that it is "not uncommon about Tucson." Rhoads ( 1892, p. I I3) also totind it in the vicinity of Tucson in summer.

57.

Fulica americana Gmelin.

\section{American Coot.}

Status-Though a few have been noted at different times in southern Arizona during the summer months, the only part of the state where the species has been found breeding is on the high Mogollor Plateau (Mearns, I8goa, p. 52). During the migrations it is quite generally distributed, while it vinters in southern Arizona.

58.

Lobipes lobatus (Linnaeus).

\section{Northiern Phalarope.}

Synonym-Phalaropus lobatus.

Status-"A flock of eight, six of which were killed, was found in a little crater lake ('Walker Lake'), August I9" (Merriam, 1890, p. 88). This record from San Francisco Mountain is the only one for Arizona.

59.

Steganopus tricolor Vieillot.

\section{Wilson Phalaroper.}

Synonyms-Phalaropus avilsoni; Steganopus avilsoni.

Stat1s--Found on the Coloracio River in September by Cones (1866a, p. 263), in southeastern Arizona by Henshaw (1875 b, p. 45I), whe found it common in August, and at Tucson, where Scott (1886, p. 386) found it "common during the migrations."

60.

\section{Recurvirostra americana Gmclin.}

\section{American Avocerit.}

Status-Has been noted during the fall migration at various points on the Colorado River, the Little Colorado, the Gila, and in the vicinity of Tucson. There is a specimen in the Museum of Vertebrate Zoology (no. 7069) taken, probably by W. W. Holder, at "Mineral City" (Ehrenberg), February I2, I864.

6 I.

\section{Himantopus mexicanus (Müller).}

\section{BLACK-NECKED Stilt.}

Synonym-Himantopus nigricollis.

Status-Recorded only from points on the Colorado River, where Coues (1866a, p. 263) met with it in September, and Stephens (1903, p. 77) in August. It should occur during the migrations throughout southern Arizona at least. 
62.

\section{Gallinago delicata (Ord).}

WiLson SNIPE.

Synonyms-Scolopax wilsonii; Gallinago wilsonii.

Status-A migrant occurring throughout the state. Was found on Bill Williams Fork in February (Kennerly, 1859 , p. 34), and is of occasiona! occurrence in winter in southern Arizona.

63.

Macrorhamphus griseus scolopaceus (Say).

LONG-BILLED DOWITCHER.

Synonym-Macrorhamphus griseus.

Status-There is but little information at hand pertaining to the occurrence of this species in Arizona. Coues ( $1866 \mathrm{a}$, p. 97) speaks of it as being "sparingly distributed throughout the Territory", without citing any specific instances of its capture. Henshaw ( 1875 b, p. 453) lists a specimen from Mimbres, Arizona, October 22, and comments that the species is "apparently an uncommon visitor in Arizona." A specimen entered in the British Museum Catalogue of Birds (Sharpe, 1896, p. 399) : "o ad., Arizona, Oct. 22, C. G. Newberry", is probably the same one alluded to by Henshaw.

These are all referred to as Macrorhamphus griscus, but it seems more probable that the form occurring in Arizona is $M . g$. scolapaceus. I have seen no specimens from the region.

64.

Pisobia bairdi (Cones).

BAIRD SANDPIPER.

Synonyms-Tringa schinzii; Actodromas bairdi; 'Tringa bairdi.

Status--Henshaw (1875b, p. 455) found it quite numerous in the fall in southeastern Arizona, taking specimens at Camp Apache, August 26-20, and at Camp Crittenden, September 2. Merriam ( 1890, p. 88) met with it at Walker Jake. San Francisco Motntain, August 27 and September I. Not reported from the Colorado River.

65.

Pisobia minutilla (Vieillot).

LIAST SANDPIPER.

Synonyms-Actodromas minutilla; Tringa minutilla; Limonites minutilla.

Status-A common migrant throughout the state. It is probably a winter visitant in parts of southern Arizona and along the lower Colorado River, but the only definite rccord of a winter bird is of a specimen mentioned by Cooke (I9IO, p. 4I), as in the United States National Musetum, collected in winter in southern Arizona, no definite date or locality being given.

66.

Pelidna alpina sakhalina (Vieillot).

RI:D-BACKED SANDPIPER.

Synonym-Tringa alpina pacifica.

Status-Recorded by Scott ( 1886, p. 386), who secured specimens near Tucson in April, r883. Apparently not otherwise observed in Arizona. 
67.

\section{Ereunetes mauri Cabanis.}

WESTERN SANDPIPER.

Synonyms-Tringa pusilla; Ercunctes pusillus; Ereunctes occidentalis.

Status--A common migrant throughout the state: Fort Apache, August 28, 29 (Henshaw, 1874, p. 145) ; Tucson, spring and fall (Scott, I886, p. 386) ; San Francisco Motintain, Septemier I (Merriam, I890, p. 88). On the lower Colorado River at least, a winter visitant (Price, I899, p. 9I).

68.

Totanus melanoleucus (Gmelin).

\section{GREATER YELLOW-LEGS.}

Synonym-Gambetta melanoleuca.

Status-Has been observed in Arizona on but a few occasions, and at scattered localities. Cones ( I 866 a, p. 98) states that it is "abundant on the Colorado." Reported from Bill Williams River in February (Kennerly, I859, 1). .34) ; from 'Tucson in October (Scott, 1886, p. 386) : and from the Pima Indian Reservation, south of Phoenix, in September (Breninger, Igora, p. 45).

ถ்.

\section{Helodromas solitarius cinnamomeus (Brewster).}

WESTERN SOT.ITARY SANDPIPER.

Synonyms-Rlyacophilus solitarius; Totanus solitarius; Hclodromas solitarius.

Status-An abundant migrant in suitable localitics throughout the state.

70.

Catoptrophorus semipalmatus inornatus (Brewster).

WESTERN WILLET.

Synonyms-Totanus semipalmatus; Symphemia scmipalmata.

Status-The only records for Arizona (beside the general statement of Woodhouse that he found this species abundant in the fall in "New Mexico") are those of birds seen by Cones (1866a, p. 97) near Fort Whipple, on October 18, 1864; and of one collected in "Arizona" by Biscioff, May 5, 1871 (Henshaw, I875b, p. 457).

71.

Bartramia longicauda (Bechstein).

BARTRAMIAN SANDPIPER.

Synonyms-Actiturus bartramius; Tringoides bartramius.

Status-Woodhouse reported this species as common in parts of "New Mexico", but the only specimen definitely known to have been taken in Arizona is one collected by Henshaw (1875b, p. 461) at Sulphur Spring, Cochise County, Augu1st 18,1874 .

72.

\section{Actitis macularius (Linnaets).}

\section{SPOTTED SANDPIPER.}

Synonym-Tringoides macularius.

Status-A common migrant throughout the state, and probably to be found on the lower Colorado River during the winter months. Found breeding on San Francisco Mountain at an elevation of ro,000 feet (Mearns, I8goa, p. 82). 
LONG-BII.LED CURLEW.

Synonym-Numenius longirostris.

Status-Coues ( 1866 a, p. 98) secured a specimen at Fort Whipple in Aug1!st, 1864: Scott (1886. p. 386) recorded it as a migrant about T'ucson, on the anthority of Brown; Sloanalier (1913. p. 195) reports a specimen from Tucson, October 12, IG, 1; and Stephens (1903, p. 77) noted it on the Colorado River, at Ehrenberg, in August. These are all the records for Arizona.

0xyechus vociferus (Linnaeus).

\section{KILI.DEE,R}

Synonyms-Charadrius rociferus; Aegialitis vociferus.

Status-A common summer visitant, and, along the lower Colorado River at least, a winter visitant also. Breeds in suitable localities throughout the state, except in the arid Lower Sonoran southwestern portion. Common in summer in the valleys of southeastern Arizona; in the Mogollon Plateau region it ranges up to 7000 feet (Mearns, $1890 a$, p. 52).

75.

AEgialitis semipalmata (Bonaparte).

SEMIP.ALMatéd Plover.

Status-Seen by Couses (1866a, p. 96) on the Colorado River in September and October, 1865 ; Scctt ( I886, p. 387) found it abundant in the vicinity of Tucson, during April, 1883. These are the only recorcis.

76.

Podasocys inontanis (Townsend).

Mountain Flover.

Synonyms-Egialitis montanus; Fudromias montanus.

Status-Cones ( 1866 a, p. 96) met with this species, presumably at Fort Whipple, and says that it is "sparingly distributed throughout Arizona." The only other record from Arizona is that of Osgood (I903, p. I28), who found it ahundant at Sulphur Spring, Cochise County, in December and January.

77.

Colinus ridgwayi Brewster.

\section{MASKED BOB-WHITE.}

Synonyms-Orty.x airginianus; Orty.x graysoni; Orty.x ridgacayi.

Status-This species formerly occupied a very limited region in extreme southern Arizona. Baboquivari Peak on the west, and the Huachuca Mountains on the east, were about the limits of its extension, nor was it known to range more than thirty or forty miles north of the Lnited States-Mexican boundary line. It is now supposed to be nearly or quite extinct in Arizona; there is no reliable published account of a specimen secured in the state since I 888 .

78.

Callipepla squamata squamata (Vigors).

Scaled Quail.

Status-A common resident of the arid, semi-desert, Lower Sonoran valleys of southeastern Arizona, usually below 4000 feet, occasionally up to 4500 fect. Has been found as far west as the Altar Valley and Wood's Station, ninety 
miles southwest of Tucson (Bendire, I892, p. I8). It ranges up the valley of the Santa Cruz River to a point some thirty miles south of Tucson; along the western base of the Santa Rita Mountains it reaches a little farther north. It is abundant on the east side of the Santa Ritas and in the valley of the San Pedro River from the Mexican boundary line to the east slope of the Santa Catalina Mountains. The northernmost points of record are Fort Grant (Henshaw, $1875^{\mathrm{b}}$. p. 442), Picacho Station, on the Southern Pacific railroad, this probably an extreme, possibly an unusual, extension of range (Brewster, 1883 , p. 33), and the Gila River near Clifton (Bendire, 1892 , p. 18 ).

Although the character of country inhabited by this species and Lophorty.x gambcli is very similar, there are but few points where the two occur together, and where this occurs one or the other is usually greatly in preponderance.

79.

Lophortyx gambeli Gambel.

\section{Desert QuaIL.}

Synonyms-Callipcpla gambeli; Lephorty'x californicus.

Status-Though most abundant in the valleys of the lower Colorado and the Gila rivers, this species is quite generally distributed, in the lowlands, throughout the southern and western two-thirds of the state. It is not known to occur in the northern plateau region, north of Fort Apache and the Mogollon Mountains and east of Bill Williams Mountain and Cataract Cañon; and until recently it was very rare in the extreme southeastern corner of the state, the southern half of Cochise County. Of late years has become much more common in the vicinity of Tombstone and the Dragoon Mountains. Occurs in the latter range up to 5000 feet (F. C. Willard, MS).

So.

Cyrtonyx montezumae mearnsi Nelson.

\section{Mearns Quail.}

Synonyms-Cyrtony'x masscna; Cyrtony.x montczumac; Fool Quail.

Status-Found in the Upper Sonoran and Transition of central and southeastern Arizona. It has been recorded from the following mountain ranges: Chiricahua, Huachuca, Carmelita, Patagonia, Santa Rita, Whetstone, Rincon, Santa Catalina, Pinal, White and Mogollon mountains. The most northern and western record is from the vicinity of Fort Whipple. The range is thus very "spotty" and broken, the intervening valleys between the various ranges being, for the most part, entirely unsuited to the species. The vertical range is from 4000 to 9000 feet.

$8 \mathrm{I}$.

Dendragapus obscurus obscurus (Say).

Dusky Grouse.

Synonym-Canace obscurus.

Status-Conmmon in the White Mountains (Mearns, I890a, p. 52). There is a record of a single bird seen on San Francisco Mountain (Merriam, 1890, p. 89). 
82.

Meleagris gallopavo merriami Nelson.

Merriam Turkety.

Synonyms-Mcleagris galloparo; Mcleagris mexicana.

Status-This species was probably at one time pretty generally distributed throughout the state, south of the Grand Cañon of the Colorado and the Little Colorado River, reaching its western limit, in southern Arizona about the valley of the Santa Cruz, in the north, about the head of Bill Williams River. Now driven back to the most remote mountain ranges, and even in many such, neariy or quite exterminated.

83.

Columba fasciata fasciata Say.

BAND-TAILED PIGEON.

Status-A common summer visitant in suitable localities throughout the state; that is, in the higher mountain ranges, breeding usually above 6000 feet. Has been found in summer on San Francisco Mountain, Mount Graham, and the White, Mogollon, Santa Catalina, Huachuca, and Carmelita mountains. Is locally migratory, but probably to be found somewhere in the state at all times of the year. I know of no definite midwinter records.

84.

Zenaidura macroura marginella (Woodhouse).

Western Mourning Dove.

Synonyms-Ectopistes carolinensis; Zenaidura carolinensis; Zcnaidura macroura; Zenaidura macroura carolinensis.

Status-A common summer visitant throughout the state, occurring in places in almost incredible numbers. In the valley of the lower Colorado River, and locally in southern Arizona, it is found throughout the winter.

85

Melopelia asiatica trudeaui (Audubon).

WHITE-WINGED DOVE.

Synonyms-Columba lencoptera; Mclopclia leucoptera; Mclopelia asiatica.

Status-A common summer visitant, locally, in southern and western Arizona. Its range in the state seems to be restricted to the valleys of the lower Coloracio and Gila rivers, and the tributaries of the latter (San Pedro, Santa Cruz, Verde, and Salt rivers), in which it ranges up to about 4000 feet. Extends at least as far north as Needles(Stephens, I903, p. 77), and Fort Whipple (Coues, I866a, p. 93). Seen in small numbers at Tucson throughout the winter (Bendire, I892, p. 146$)$.

86.

\section{Chaemepelia passerina pallescens Baird.}

\section{Mexican Ground Dove.}

Synonyms-Chamaepelia passcrma; Columbigallina passerina.

Status-Locally common in southern Arizona, ascending the valley of the Colorado as far north as the Big Sandy (Stephens, I903, p. 77), in the interior to Fort Verde (Todd, I9I3, p. 594). It is partly migratory but stays through the winter in parts of its range. Specimens in the collection of F. S. Daggett taken at Fort Lowell in November and December. According to Gilman ( 19 I I b, p. 54) it is a summer visitant only at Sacaton. 
87.

Scardafella inca (Lesson1).

IXCA DOVE.

Status--Exceedingly local, and recorded from very few points-'Tucson, Phoenix, Fiorence, Tubac (in the Santa Cruz Valley), and the Huachuca Mountains. It particularly favors the towns and settlements, a trait shared to some extent by the Mexican Ground Dove, and is probably more abundant in the vicinity of Phocnix than anywhere else in the state. Reported as a permanent resident at Sacaton, Pinal County (Gilman, I9I Ib, p. 55).

88.

Cathartes aura septentrionalis Wied.

TURKEY VULTURE.

Synonyms-Cathartes aura; Rhinogryphus aura.

Status-A common summer visitant throughout the state; reported from many scattered localities, generally below 6000 feet: Fort Whipple, summer; Santa Catalina Mountains, resident: San Francisco and Mogollon mountairis, summer; Keam Cañon, summer; Huachuca Mountains, summer; Santa Rita Mountains, summer. Breeding on the east slope of the Santa Catalina Mountains, in the Dragoon Mountains, and in the Huachua Mountains (F. C. Willard, MS). It remains during the winter in parts of southern Arizona.

89.

Circus hudsonius (Linnaeus).

Marsht Hawk.

Synonyms-Circus cyancus; Circus cyancus var. hudsonius.

Status-An abundant migrant, and, in southern Arizona at least, a common winter visitant (Scott, I886, p. 422; San Pedro River, January). Found breeding near Tucson by Bendire ( 1892 , p. 185 ).

9o.

\section{Accipiter velox (Wilson).}

\section{Sharp-Shinnied Hawk.}

Synonyms-Accipiter fuscus; Nisus fuscus; Accipiter velox rufilatus; Acripiter ielox pacificus.

Status-Probably breeds in small numbers in the higher mountains throughout the state, but thougli observed during the summer months there are no definite published statements of its breeding anywhere in Arizona. Found nesting in the Huachuca Mountains. a set of eggs being taken in Miller Cañon, at an altitude of 6800 feet, May 30, I907 (F. C. Willard, MS). It is a very common migrant throughout the state, and has been seen in southern Arizona during the winter, at the San Pedro River in January (Scott, 1886, p. 422), and at Sulphur Spring, Cochise County, in November (Osgood, I903, p. I29).

91.

Accipiter cooperi (Bonaparte).

COOPER HAwk.

Synonyms-Accipiter mericanus; Nisus cooperi.

Status-A very common resident, breeding in suitable localitics throughout 
the state, in Lower and Upper Sonoran, and to at least the lower edge of Transition. There are breeding records from Picacho, Colorado River (Mus. Vert. Zool.) ; Santa Cruz River near Tucson (Swarth, 1905a, p. 25); Huachuca Mountains (Swarth, 1904b, p. 6) ; Santa Rita Mountains (Brewster, I883,-p. 30) ; Santa Catalina Mountains (Scott, 1886, p. 422); and Fort Grant (Coues, 1868, p. 82). It remains locally through the winter.

92.

Astur atricapillus atricapillus (Wilson).

Amirican Goshawk.

Synonyms-Accipiter atricapillus; Accipiter atricapillus striatulus.

Status-There are very few records of the occurrence of this species in Arizona: On San Francisco Mountain, where several were seen (Merriam, I8yo, p. 90) ; a few individuals in the Mogollons in May and on San Francisco Mountain in June (Mearns, I890a, P. 53); and in the Huachuca Mountains, where it is a rare migrant (Swarth, Igo4b, p. 6).

93 .

\section{Parabuteo unicinctus harrisi (Audubon).}

HARRIS HaWK.

Synonyms-Morphnus unicinctus; Craxirex unicinctus; Craxirex harrisii.

Status-Recorded from the Colorado River in February (Kennerly, 1859, p. 20), and at Ehrenberg in August (Stephens, 1903, p. 77). It ranges across southern Arizona, and has been found breeding in the vicinity of Tucson (Bendire, I892, p. 202), and at the east base of the Huachuca Mountains, where a set of eggs was collected June I, IgO7 (F. C. Willard, MS). Seen on the San Pedro River, in extreme southeastern Arizona, in February (Willard, I9Ioc, p. IIo).

34.

\section{Buteo borealis calurus Cassin}

WHSTERN RED-TAILED HAWK.

Synonyms-Buteo borealis; Buteo calurus; Buteo montanus.

Status-An abundant resident, found in all parts of the state. Breeds from Lower Sonoran up through Transition, exact points of record being Rillito Creek near Tucson, Camp Crittenden, Santa Catalina Mountains, and the pine belt of the Mogrollon Mountains.

95.

\section{Buteo abbreviatus Cabanis.}

\section{ZONE-TAILED HAWK.}

Synonym-Buteo zonoccrus.

Status-Generally distributed throughout southern Arizona. Recorded from many localities (Colorado River, Santa Cruz. Valley, Rincon Mountains, etc.) north to the Verde Valley, Prescott, and the Big Sandy. Numerous breeding records, mostly in the Upper Sonoran zone: T'ucson (Brewster, I883, p. 30) ; New River (Mearns, I886a, p. 60) ; Huachuca Mountains (Bendire, I887, p. 551) ; Rincon Mountains (Brown, I901, p. 392) ; east slope of Santa Catalina Mountains (F. C. Willard, MS). Except along the lower Colorado it seems to go south of Arizona in the winter. Seen at Yuma in winter (Price, 1899, p. 91). 
96.

\section{Buteo swainsoni Bonaparte.}

SWAINSON HAWK.

Synonyms-Buteo bairdi; Butco insignatus; Butco oxypterus.

Status-An abundant summer visitant on the plains in extreme southeastern Ariznna ('Tucson, Fort Grant. Fort IJuachuca, etc.); also found breeding near Yuma (Brown, 1903, p. 44). During the migrations it is more widely distributed. Has not been observed in Arizona during the winter months.

97.

\section{Buteo albicaudatus sennetti Allen.}

SENNETT WHITE-TAILED HAWK.

Status-A nest found by G. F. Breninger between Florence and Red Rock in 1897 , and a male bird taken by the same collector at Phoenix in the spring of I899 ( 1899 c, p. 352). Not otherwise observed in Arizona.

98.

\section{Urubitinga anthracina (Lichtenstein).}

Mexican Black Hawk.

Status-The only breeding record is from the vicinity of Fort Verde, in central Arizona (Mearns, I886a, p. 60). Other points at which the species has been observed are Forts Bowie, Lowell, and Huachuca. Its occurrence at Fort Bowie in February (Fowler, I903, p. 70) indicates that it remains throughout the year in some parts at least of southern Arizona.

99.

Asturina plagiata Schlegel.

Mexican Goshawk.

Synonyms-Asturina nitida; Asturina nitida plagiata.

Status-The center of its abundance in Arizona seems to be the valley of the Santa Cruz River, where it is not uncommon during the summer months. It has also been found breeding on Rillito Creek (a tributary of the Santa Cruz), in the foothills of the Santa Rita Momntains, on the San Pedro River, and, the westernmost record, on the Gila River in the vicinity of Gila Bend (Pember, I 892 , p. 53).

100.

Archibuteo lagopus sancti-johannis (Gmelin).

AMERICAN ROUGH-LEGGED HAWK.

Synonym-Archibuteo lagopus.

Status-A specimen taken by Cones (1866a, p. 48) at Fort Whipple in the winter of 1865 . Henshaw (I875a, pp. I63, I64) cites Benclire as having met with the species at Tucson in winter.

IOI.

Archibuteo ferrugineus (Licintenstein).

FERRUGinous Rough-LEGrED HAivK.

Status-Cones (I866a, p. 46) found this species abundant in winter in the vicinity of Fort Whipple. Fisher (1893a, p. 9I) records a specimen taken at Fort Verde in December. The few other Arizona records are either of doubtfully identified birds, or else are not explicit statements of the place or manner of occurrence. It has not been found breeding in Arizona. 
I 02. Aquila chrysaëtos (Linnaeus).

GOLDEN EAGLE.

Synonyms-Aquila canadcnsis; Aquila chrysactus var. canadensis.

Status-A fairly common resident of the higher mountain ranges in northern Arizona, and in the eastern part of the state south to the Mexican boundary line. Found breeding at Prescott (Coues, I892b, p. 20I); reported as resident in the Santa Catalina Mountains (Scott, I886, p. 423), and in the Huachuca Mountains (Swarth, 1904b, p. 7) : an old nest seen in the latter range (Swarth MS). Recorded from various other scattered localities: in summer, San Francisco Mountain, Santa Catalina Mountains, Keam Cañon, etc.; in fall and winter, Grand Cañon, Fort Whipple, Huachuca Mountains, etc. Not observed anywhere in the western deserts.

I03. Haliaeëtus leucocephalus leucocephalus (Linnacus).

\section{BALd EAGLE.}

Status-Reported by Mearns (I890a, p. 5.3) as breeding at Stoneman's Lake, in the Mogollon Mountains. Cones met with it at Fort Whipple, and Henshaw at Fort Apache in southeastern Arizona; a specimen is listed by Fish $2 r$ (1893a, p. 97) as collected in the Mogollon Mountains in January.

I04.

Falco mexicanus Schlegel.

Prairie Falcon.

Synonyms-Falco polvagrus; Falco lanarius var. polyagrus; Falco saker var. polyagrus.

Status-Fairly conmon resident throughout the state; reported from many different points, winter and summer. Found breeding on San Francisco Mountain (Merriam, 1890, p. 90), and in the Huachuca Mountains (Howard, I902, p. 57), and an occupied nesting site observed on the Colorado River near the mouth of Bill Williams River in the spring of Igro (Mus. Vert. Zool.).

I05.

Falco peregrinus anatum Bonaparte.

Duck Hawk.

Synonyms-Falco anatum; Falco nigriccps; Falco communis var. anatum.

Status-Resident and apparently common in the mountains of central Arizona (Mearns, $1890 a$, p. 54). In the more sonthern parts of the state it is a rather uncommon migrant.

Iо6.

Falco columbarius columbarius Linnaeus.

Pigeon Hawk.

Synonym-Hypotriorchis columbarius.

Status-I know of no instance of this species breeding in Arizona. It occurs as a fairly common migrant, and, in some localities, possibly as a winter visitant. 
107.

Falco columbarius richardsoni Ridgway.

Richiardson MERLin.

Synonyms-Falco richardsoni; Falco acsalon.

Status-Cooper secured an adult female at Fort Mohave, January 2I, I86I (Mus. Vert. Zool., 11o. 4388), and Fisher (1893a, p. II 4) lists one collected at Fort Verde, December 9, 1887 , the only definite records I know of for Arizona. Coues' (1866a, p. 42) comments on Falco acsalon undoubtedly refer to this species, but give no clue as to its status in the region he explored.

I08.

Falco fusco-caerulescens Vieillot.

Aplomado Falcon.

Synonyms-Falco femoralis; Hypotriorchis femoralis.

Status-Formerly, at least, a fairly common summer visitant in extreme southeastern Arizona. Henshaw ( $1875 \mathrm{~b}, \mathrm{p} .4 \mathrm{I} 3$ ) observed it in this region in I874, and Bendire ( 1887, p. 552) describes its nesting near Fort Huachuca. Has been met with but seldom of late years. One seen on the San Pedro River, near Fairbanks, February I3, I9I0 (Willard, I9IOc, p. II0).

IO9.

Falco sparverius sparverius Linnaeus.

American Sparrow Haink.

Synonyms-Tinnunculus sparzerius; Falco sparverius deserticolus; Falco sparicrius phaloena.

Status-An abundant resident of general distribution, breeding both in the valleys and in the mountairis. There are, among cthers, breeding records from Fort Whipple, Santa Catalina Mountains, Huacluca Mountains, Mogollon Mountains, and Santa Cruz River near Tucson, these points being variously in the Lower Sonoran, Upper Sonoran, and Transition zones. It is locaily migratory, but probahly to be foind in most of the lower valleys during the winter. Explicit winter records are from Fort Whipple, Tucson, Sulphur Spring Valley, and the San Pedro River.

I IO.

Polyborus cheriway (Jacquin).

Audubon Caracara.

Synonyms-Polyborus tharus; Polyborus audubonii; Polyborus tharus var. auduboni.

Status-Apparently not common. Reported from the vicinity of Tucson in summer, and from Yuma, doubtfully identified by Price (I899, p. 9I), and the Salt River (Fisher, 1893a, p. I28) in winter. Found breeding sixteen miles southwest of Tucson by Herbert Brown (Bendire, 1892, p. 317).

I I I.

Pandion haliaëtus carolinensis (Gmelin).

AMERICAN OSPREY.

Synonym-Pandion carolinensis.

Status-There seem to be no breeding records for the state though specimens have been taken in the summer months (see Fisher, I893a, p. I30). Reported from scattered localities throughout Arizona during the migrations, usually along the larger streams. 
I 12.

Aluco pratincola (Bonaparte).

AMERICAN BARN OWL

Synonyms-Strix pratincola; Strix americana; Strix flanmea var. americana; Strix flammea; Aluco flammeus pratincola.

Status-Probably most abundant in the central portions of the state. Coues ( $1866 \mathrm{a}$, p. 49) states that it is a common resident at Fort Whipple, and Fisher (I893a, p. I32) lists numerous specimens from Fort Verde, taken in May, July, October and December. There are no records from the northern plateau region, anci in southern Arizona it is rare. Found breeding at 'Tombstone on several occasions (F. C. Willard, MS). Found breeding also near Pilot Knob, on the Colorado River (Mus. Vert. Zool.). This was on the California side of the stream, but in the absence of Arizona records from the region, may be cited as evidence of the manner of occurrence of the species in this valley.

113.

Asio wilsonianus (Lesson).

American Long-EARFid OwL.

Synonyms-Otus americanus; Otus zvilsonianus; Otus vulgaris var. wilsonianus; Asio americanus.

Status-Apparently of rare occurrence. Reported during the migrations and in the winter, from various scattered localities throughout the state: Fort Whipple; Tucson, February; Fort Verde, January, February; Sulphur Spring, April ; Fort Huachuca, April.

I I 4 .

Asio flammeus (Pontopiddan).

SHORT-EARF̣D OWL.

Synonyms-Strigiceps uliginosus; Brachyotus cassinii; Otus brachyotus; Asio accipitrinus.

Status-A migrant and winter visitant. Reported from Fort Whipple, Colorado River, Fort Bowie, Gila Bend, and Sulphur Spring Valley. Met with by but a few observers, and in small numbers, except as reported by Coues (I866a, p. 50), who found it common on the Colorado River.

I 15 .

Strix occidentalis huachucae Swarth.

Arizona SiótTed OWL.

Synonyms-Syrnium occidcutale; Strix occidcntalis.

Status-A resicient, probably not very uncommon, in the higher mountains of sotitheastern Arizona. There seem to be published records of its occurrence only from the vicinity of Tucson (Ridgway, 1874, p. 239; Bendire, 1892, p. 343) and from the Huachuca Mountains (Swarth, I9Iob, p. I).

II6.

Cryptoglaux acadica acadica (Gmelin).

SAW-WHE'T OWL.

Synonym-Nyctale acadica.

Status-Known only from the record by Mearns (1890a, p. 54), who found it breeding on San Francisco Mountain. 
I 7 .

\section{Otus asio cineraceus (Ridgway).}

\section{Mexican SCREECH OWL.}

Synonyms-Scops mccalli, part; Megascops asio trichopsis, part; Megascops asio cineraceus, part; Scops asio, part; Scops asio var. maccalli, part.

Status-A common resident of the Upper Sonoran zone in southern Arizona. It has not been found on the plateau region of northeastern Arizona.

I 18.

\section{Otus asio gilmani Swarth.}

Sahuaro Screich Owl.

Synonyms-Scops mccalli, part; Scops asio; Scops asio var. maccalli, part; Scops asio trichopsis; Scops trichopsis; Megascops asio trichopsis, part; Megascops asio cineraceus, part; Otus trichopsis, part.

Status-A common resident of the hot Lowet Sonoran valleys of southern and western Arizona. Ranges east to Tucson and the valley of the Santa Criiz River, west to the Colorado River; it ascends the latter stream at least as far as Fort Mohave (a specimen collected by Cooper at Fort Mohave, February 24, I86I, no. 4395, coll. Univ. Calif. Mus. Vert. Zool.).

II9.

Otus trichopsis (Wagler).

SPOTTED SCREECH OWL.

Synonyms-Megascops aspersus; Megascops trichopsis.

Status-The Huachuca Mountains seen!s to be the only place in the United States where this species has been found, though it undoubtedly occurs also in some of the neighboring mountain ranges. In the Huachucas it is known as a rare summer visitant, about ten specimens having been secured. A set of three eggs taken in that range on June I9, I90I, by G. F. Breninger, and now in the collection of the Field Museum of Natural History, establishes a breeding record for the region. The parent bird being taken with the set (no. I6234 coll. Field Mus. Nat. Hist.) renders the identity unquestionable.

120.

\section{Otus flammeolus (Kaip).}

Flam Mutatitid (SCRETichi ) Oivt.

Synonyms-Scops flammcola; Megascops flammcolus.

Status-Probably a fairly common summer visitant of the higher mountains throughout the state. Specimens have been secured at the Grand Cañon (Merriam, I890, p. 39), near Camp Apache (Henshaw, 1875b, p. 406), in the Huachuca Mountains (Swarth, I904b, p. 9), and in the Chiricahua Mountains (specimen in Mus. Vert. Zool.). It has been found breeding in the Huachucas (Willard, Igogc, p. 199).

I2I.

\section{Bubo virginianus pallescens Stone.}

WESTERN HORNED OWL.

Synonyms-Bubo magcllanicus; Bubo virginianus; Bubo virginianus pacificus; Asio magellanicus pallescens; Bubo magellanicus pallescens; Bubo virginianus var. arcticus; Bubo virginianus subarcticus; Bubo zirginianus saturatus; Asio magellanicus pacificus. 
Status-A fairly common resident, reported from all parts of the state. Found in Lower Sonoran (Ttucson, Gila River, etc.), Transition (Huachuca Mountains, Hualpai Mountains) and Boreal (spruce belt of San Francisco Mountain: Merriam, I890, p. 9I).

122. Speotyto cunicularia hypogaea (Bonaparte).

Burrowing OwL.

Synonyms-Athene hypugaea; Athene cunicularia.

Status-Irregularly and locally distributed throughout the valleys of the state. In general it may be said to be common where the Prairie Dog (Cynomys) is found, in the lower Sonoran valleys of northeastern and southeastern Arizona, and decidedly rare elsewhere. Sparingly distributed across the plains of south. western Arizona.

I 23.

Glaucidium gnoma pinicola Nelson.

(Rocky Mountain) Pigmy Oiwl.

Synonyms-Glaucidium passcrinum var. californicum, part: Glaucidium gnoma.

Status-A resident in the Transition zone of the higher mountains throughout the state. Reported from many scattered localities: Prescott, San Francisco Mountain, Huachuca Mountains, Chiricahua Mountains, Mogollon Mountains, White Mountains.

I24.

\section{Glaucidium phaloenoides (Daudin).}

Ferruginous Pigmy Owl.

Synonyms-Glancidium ferrugincum; Glancidium passerinum var. californicum, part.

Status-Apparently restricted to the valley of the upper Gila River, and its tributaries (Salt River, Santa Cruz River, etc.), where it is not uncommon. Has not been taken west of Gila Bend. A bird of the Lower Sonoran zone almost exclusively. Probably resident, though I know of no definite winter records.

I 25.

\section{Micropallas whitneyi (Cooper).}

ElF OwL.

Synonyms-Athene whitneyi; Micrathene whitneyi.

Status-A common species in the Lower Sonoran zone in southern Arizona, from the valley of the Santa Cruz, and the Catalina Mountains, west to the Colorado River; north along the latter to the Big Sandy River (Stephens, I903, p. IOI) and Fort Mohave (Cooper, I86I, p. I18). During the breeding season it is almost entirely restricted to the region occupied by the giant cactus. There is, however, a breeding record from the Huachuca Mountains (Fisher, 1904, p. 80). It is probably migratory to some extent, as the records from scattering points outside the proper breeding range would indicate: Fort Mohave, April; Dragoon Mountains, April; Fort Bowie, October; etc. 
I 26.

Rhynchopsitta pachyrhyncha (Swainson).

THICK-BILlED PARROT.

Status-Known only as an irregular, occasionally abundant, mid-summer visitant to the Chiricahua Mountains (see Lusk, I900, p 129; Smith, I907a, p. I04).

I 27 .

Crotophaga sulcirostris Swainson.

GROOVE-EILLED ANI.

Status-A single bird recorded as taken near the Huachuca Mountains in May, I888 (Poling, I89I, p. 3I3).

128.

Geococcyx californianus (Lesson).

ROADRUNNER.

Synonym-Geococcyiv viaticus.

Status-A fairly common resident of the valleys and foothills below Transition. Reported from many low zone localities in all parts of the state. Probably breeds mainly in the Lower Sonoran zone, wandering to somewhat higher altitudes in late summer.

129.

Coccyzus americanus occidentalis Riclgway.

California Cuckoo.

Synonym-Coccyzus americanus.

Status-A summer visitant, fairly common, but of irregular distribution. It is found in the valleys of southern Arizona, along the Gila River and its tributaries, and also along the Colorado River, but has not been detected in the high plateau region of northeastern Arizona. Breeds mainly in the Lower Sonoran zone, but also, in limited numbers, in Upper Sonoran almost to the lower edge of Transition (Swarth, I904b, p. Io).

I 30 .

\section{Trogon ambiguus Gould.}

COPPERY-TAILED Trogon.

Status-A rare and irregular summer visitant in the Transition of some of the higher mountains of extreme southern Arizona. Reported from the Huachucas (Ridgway, I887a, p. I6I ; I887b, p. I47; Fowler, 1903, p. 69; etc.), the San Luis Mountains (Ridgway, I9II, p. 77I) and, doubtfully, from the Santa Catalina Mountains (Scott, I886, p. 425):

I3I.

Ceryle alcyon alcyon (Linnaeus).

\section{BELTED KINGLISHER.}

Statıs--A fairly common migrant in all parts of Arizona. Although reported as a permanent resiclent, or as a summer visitant, by several observers (Coues, I866a, p. 59; Scott, I886, p. 425; Bendire, I895, p. 34), I know of no specific instance of a nest having been found. Remains through the winter in some of the ivarner southern valleys: Tucson (Scott. 1. c.), Colorado River, below Yuma (Price. I899, p. 92). 
I.32.

Ceryle americana septentrionalis Sharfe.

TEX.IS KingFisher.

Synonym-Ceryle americana.

Status-Coues (1866c, p. 263) observed this species at points on the Colorarlo River hetween Forts Mohave and Yuma, in September, I365. Since that time it was not again met with until February I3, I9Io, when F. C. Willard secured a single specinen, an adult male, on the San Pedro River, near Fairbanks (Willard, Igloc, p. I IO). This specimen is now in the University of California Museum of Vertebrate Zoology (110. r3990).

I33.

Dryobates villosus leucothorectis Oberholser.

WHITE-BREASTED WOODPECKER.

Synonyms-Picus harrisii; Picus iillosus harrisi; Dryohates villosus harrusi; Dcndrocopus herrisi; Dryohatcs ailiosus hyloscopus; Dryobates villosis icastus.

Status-A common resident of the higher mountains throughout the state. Breeds in the Canadian and Transition zones, but is of occasional occurrence in winter in some of the lower valleys: Verde Valley in winter (Mearns, I8goa, p. 25I ); Tucson, winter (Bendire, I895, p. 53 ).

I34. Dryobates pubescens homorus Cabanis and Heine.

BATCHELDE, WOONPECKER.

Synonyms-Picus pubescens; Picus gairdneri; Picus pubescens gairdneri; Dryobates pubescens gairdneri; Dryobates pubescens oreoecus.

Status-There are bıt few records of the occurrence of this species in Arizona. Henshaw ( 1875 b, p. 388) met with it on the Gila River in October, Scott ( 1886, p. 426) secured a single specimen at Riversicie (also on the Gila River) in April, I882, while Mearns (I890a, p. 252) found it breeding sparingly in the pine and spruce zones of the San Francisco and Mogollon mountains.

I 35 .

Dryobates scalaris cactophilus Oberholser.

CACTUS WOODPECKER.

Synonyms-Picus scalaris; Dryobates scalaris; Dryobates scalaris bairdi.

Status-A common resident of the Lower Sonoran zone throughout southern and western Arizona. It ranges north to Fort Apache, the south base of the Mogollon Mountains, and Fort Whipple; along the Colorado River still farther north: confluence of Beaverdam and Virgin rivers (Fisher, 1893b, p. 47).

136.

Dryobates arizonae (Hargitt).

ARIzO'va WOODPECKER.

Synonyms-Picus stricklandi; Dryobates stricklandi; Picus arizonac; Dendrocopus arizonac.

Status-A common resident of the live-oak belt of the mountains of the extreme sontheastern corner of the state. Reported from the Santa Rita, Chiricahua, Huachuca, Whetstone, and Rincon mountains, and the east slope of the Santa Catalina Mountains. 
I 37 .

\section{Picoides americanus dorsalis Baird.}

Alpine THREF-TOED WOODPECKER.

Status-A resident of the Canadian zone (pine and spruce belts) of the White, Mogollon and San Francisco mountains (Henshaw, I875b, p. 39r ; Mearns, $1890 a$, p. 252).

138.

Sphyrapicus varius nuchalis Baird.

\section{RED-NAPED SAPSUCKER.}

Synonyms-Picus varius; Sphyrapicus varius; Sphyrapicus nuchalis.

Status-A fairly common migrant, and, in extreme southern Arizona and along the Colorado River, a winter visitant. It has several times been reported as "resident" in northern Arizona, but I know of no authentic breeding record.

I39.

Sphyrapicus thyroideus (Cassin).

WILLIAMSON SAPSUCKER.

Synonym-Sphyrapicus williamsonii.

Status-Common resident in the Canadian zone of the higher parts of the White. Mogollon and San Francisco mountains (Mearns, I890a, p. 252). Farther south it is a fairly common migrant and winter visitant in the mountains, while it has once been reported from the Colorado River, at Fort Mohave (Cooper, I86I, p. I 2 I).

I 40.

Melanerpes erythrocephalus (Linnaeus).

RED-HEADED WOODPECKER.

Status-A single specimen was taken by Price in the Chiricahula Mountains, in the spring of 1894 (Bendire, I895, p. 107). This is the only record for Arizona.

I 4 I.

Melanerpes formicivorus aculeatus Mearns.

MeArNS WoOdPECKER.

Synonyms-Melancrpes formicivorus; Mclancrpes formicivorus bairdi; Mclancrpes melanopogon, part; Balanosphyra formicierora aculeata.

Status-A common resident of the live-oak regions. In northern Arizona ranges from the Grand Cañon of the Colorado (Merriam, I890, p. 39), and Bill IVilliams Mountain (Wetmore, I908, p. 379) - but not on San Fíancisco Mountain (see Merriam, I890, p. 92) -west to the Hualpai Mountains (Stephens, I903, p. IOI) and Fort Whipple (Coues, I866a, p. 55) ; extends southeastwardly throughout the state, on the southern bounclary ranging west to the Santa Rita Mountains. . Absent from the aricl southwestern portion, all that would be south and west of a line drawn from the Hualpai to the Santa Rita Montitains. Reported as a straggler at Sacaton, Septemiber 5, I9Io (Gilman, I9I Ia, p. 35). 
I 42.

\section{Asyndesmus lewisi Riley.}

\section{LEWIS WOODPF,CKER.}

Synonyms-Celeus torqualus; Melanerpes torquatus; Asyndesmus torquatus.

Status-Mentioned by Merriam (1890, p. 92) as breeding in the piñon and cedar belt on San Francisco Mountain. Elsewhere in Arizona it has been noted as an erratic visitant, present in numbers one year, and absent the next, but apt to occur almost anywhere.

I43.

\section{Centurus uropygialis Baird.}

Gila WoOdPecker.

Synonyms-Melanerpes uropygialis.

Status-A common resident of the Lower Sonoran zone in southern and western Arizona. In the eastern part of the state it does not range norti of the Salt River, but it ascends the Colorado at least to Fort Mohave; of occasional occurrence at Fort Whipple (Coues, I866a, p. 54). It is practically restricted to such parts of the valleys of the Gila River and its tributaries as lie in the Lower Sonoran zone, and to the valley of the lower Colorado River.

144 .

Colaptes cafer collaris Vigors.

RED-SHAF'TED FLICKIR.

Synonyms-Colaptes rubricatus; Colaptes mexicanus; Colaptes auratus mexicanus; Colaptes cafer.

Status-Common resident, breeding in Upper Sonoran and Transition. Breeding records from the Santa Catalina, Mogollon, Hualpai, Huachuca and Santa Rita mountains. During the migrations and in the winter it is quite generally distributed.

I 45 .

\section{Colaptes chrysuides mearnsi Ridgway.}

Mearns Gilded Ficker.

Synonyms-Colaptes ayresii; Colaptes chrysoides.

Status-A common resident of the Lower Sonoran zone in parts of southern and western Arizona, extending east to the Santa Rita and the east slope of the Santa Catalina mountains, north to Fort Mohave. Its range is almost absolutely coextensive with that of the giant cactus, the easternmost limit of the species, some twenty-five miles southeast of Tucson, being abruptly defined along the line marking the edge of the territory where the cactus grows. West of the Santa Rita Mountains in the giant cactus region, the gilded flicker is abundant, east of that range it is unknown. On the Colorado River it occurs at the few points where the cactus is found, but it has also been taken in diffierent associations, as at Fort Mohave (Cooper, I86I, p. I2I). 
146.

Antrostomus vociferus macromystax (Wagler).

STEPHENS WHIP-POOR-IVILL.

Synonyms-Antrostomus vociferus; Antrostomus vociferus arizonae.

Status-A fairly common summer visitant in some of the higher mountains of southeastern Arizona. Found in high Upper Sonoran and Transition zones in the Chiricahua, Santa Rita, Graham, Huachuca and Whetstone mountains. Reported once from the Santa Catalina Mountains, in April (Scott, I886, p. 429).

I 47 .

Phalaenoptilus nuttallii nuttallii (Audubon).

POORWILL.

Synonyms-Caprimulgus nuttallii; Antrostomus nuttallii; Phalaenoptilus nuttalli nitidus.

Status-A common summer visitant throughout the state. Definite breeding records from Arizona are rare, but the birds have been taken or observed in the breeding season in Lower Sonoran, Upper Sonoran, and the lower part of the Transition zone. It has heen found in December in the vicinity of Tucson (Bendire, I895, p. I 53).

$\mathrm{I} 48$.

Chordeiles virginianus henryi Cassin.

WESTERN NIGHTHAWK.

Synonyms-Chordciles virginianus; Chordciles popetue; Chordeiles henryi, part; Chordciles popetue henryi.

Status-Common summer visitant of the higher mountains throughout the state: Flagstaff, Fort Whipple, San Francisco Mountain, Hualpai Mountains, Keam Cañon, Whetstone Mountains, Huachuca Mountains. Apparently does not occur below Upper Sonoran, even in the migrations. Has not been observed anywhere in southwestern Arizona.

I 49.

Chordeiles acutipennis texensis Lawrence.

TExas Nighthaink.

Synonyms-Chordeiles texensis; Chordeiles henryi, part.

Status-An abundant summer visitant of the Lower Sonoran zone in southern and western Arizona. In the eastern part of the state it apparently does not occur north of the Gila River; in the west it extends to a point some fifty miles south of Fort Whipple (Cones, I866a, p. 58), and, along the valley of the Colorado River, quite to the northern boundary of the state: mouth of Beaverdam Creek (Fisher, 1893b, p. 53).

150 .

Chaetura vauxi ('Townsend).

VAUx SWIFT.

Synonyin-Acanthylis pclasgia.

Status-Apparently a rare migrant in Arizona; has been observed at but a few points. Seen in the Santa Catalina Mountains in October (Scott, 1886, p. 429), at the Pima Indian Reservation on the Gila River, in September (Breninger, IgoIa, p. 45), in the Huachuca Mountains in May (Swarth, I904b, p. I6), and along the Colorado River at Potholes, Yunza, and Pilot Knob, in April and May (Mus. Vert. Zool.). 
I 5 I.

Aëronautes melanoleucus (Baird).

WIIITE-THRO.ATED SWIF's.

Synonyms-Acanthylis saxatalis; Cypsclus melanolcucus; Panyptila melanolenca: Micropus mc!ano!cucus.

Status-Breeds commonly on rocky cliffs and precipices throughout the state. Remains through the winter in parts at least of southern and western Arizolla.

152 .

\section{Eugenes fulgens (Swainson).}

Rivoli Hummingbird.

Status-A common summer visitant of some of the higher mountains of southeastern Arizona. While apparently most numerous in the Huachuca and Chiricahua mountains, it has been reported from the Santa Ritas, the San Luis Mountains, the Santa Catalinas (one specimen, Rhoars, I892, p. II7), and Mount Graham (Henshaw, I 875 b, p. 379), the latter being probably its northern limit. The vertical breeding range-where the nests are located-is about from 5000 to 7000 feet, but the adult males are usually to be found in high Transition, above 8000 feet.

I 53 .

\section{Cyanolaemus clemenciae (Lesson).}

BlUE-THROATED HUMMINGBIRU.

Synonym-Cociigcna clemenciac.

Status-A rather uncommon st:mmer visitant in the damp shady cañons of the mountain ranges of scutheastern Arizona. Has been found in the Santa Cataina, Santa Rita. Chiricahua, Sain Luis, and Huachuca mountains. Nests and egrgs have been secured in the last mentioned range (see Breninger, I903, p. 4.35; Willard, I9I I, p. 46).

I 54 .

Archilochus alexandri (Enurcier and Mi1sant).

BLACK-CHINNFD HuMmingPiRD.

Synonym-Trochilus alc randri.

Status-Very common summer visitant, found generally in foothill country and along wonrled streams. Ranges north into the Mogollon Mountains in central Arizona, where Mearns (I\&gOa, p. 255) found it breeding in the pine belt, castually still farther north: I specimen, Keam Cañon, July $3^{I}$ (Fisher, I903, p. 35). Breeds along the Colorado River to the northern bonndary of the state.

I 55 .

Calypte costae (Bourcier).

Costa HumaingBird.

Synonyms-Sclasphorus costae; Atthis costac; Trochilus costae.

Status-Conmon summer visitant of the Lower Sonoran zone in southern and western Arizona : reported north to Fort Grant and Tucson in the east, and to Fort Mohave on the Colorado River. A few seem to remain through the winter as it has been found both at Bill Williams River (Baird, I858, p. I38) and in - the extreme southwestern corner of Arizona (Bendire, I895, p. 202) in February. Though found breeding only at low altitudes, it is of common occurrence in the high mountains during the migrations, especially in the late summer: Huachuca Mountains, 5500 feet, July (Swarth, I904b, p. I7). 
156.

\section{Calypte anna (Lesson).}

Anna Hummingibird.

Synonym-Trochilus anna.

Status-A rare autumnal visitant, reported from Camp Grant in September (Henshaw, I875b, p. 375), from the Santa Catalina Mountains in October (Scott, I886, p. 43I ), and from the Huachuca Mountains in October (Fisher, I904, p. $80)$.

Selasphorus platycercus (Swainson).

BROAD-TAILED HUMmingeirl).

Synonym-Trochilus platycercus.

Status-Common summer visitant in the higher parts of the 'Transition zone and upward, throughout Arizona; reported from practically all of the higher mountain ranges visited by collectors: White Mountains, Camp Grant, Santa Catalina Mountains, Mogollon Mountains, San Francisco Mountain, Hualpai Mountains, Huachuca Mountains, Santa Rita Mountains. But one lowland record: Sulphur Spring Valley (Osgood, 1903, p. 130).

158.

Selasphorus rufus (Gmelin).

\section{RuFous Hummingbird.}

Synonyms-Polytmus rufus; Trochilus rufus.

Status-During the late summer this species is an exceedingly common migrant in the higher mountains of the state. As it appears in numbers early in July it has been occasionally reported as a "summer resident", but it undoubtedly does not breed anywhere in Arizona. It is of comparatively rare occurrence in the spring.

I 59 .

Selasphorus alleni Henshaw.

Allen Hummingbird.

Synonym-Trochilus alleni.

Status-A rare visitant: A male secured in the Santa Catalina Mountains, July 23, I884 (Scott, I886, p. 43I); specimens taken in the vicinity of Bisbee in August and September (Allen, 1893, p. 36) ; and in the Huachuca Mountains in July, in 1896 and in 1902 (Swarth, I904b, p. I9). These are all the records for Arizona.

The Allen and Anna hummingbirds probably belong in the same category in their manner of occurrence in Arizona: species that occasionally wander to this exceptiona! distance only at the period of general dispersal in the late summer. They can hardly be regarded as migrants, following a fixed path to a definite destination. 
160.

Atthis heloisa morcomi Ridgway.

MorCOM HuMMingirird.

Synonym-Atthis morcomi.

Status-Known only from two adult females secured by H. G. Rising in Ramsay Cañon, in the Huachuca Motintains, Jully 2, 1896 (see Kidgway, I898b, p. 325). One of these two birds, the type, is in the United States National Museum; the second is in the University of California Museum of Vertebrate Zoology (no. 10299).

I6I.

Stellula calliope (Gould).

Calliope Hummingbird.

Synonym-Trochilus calliope.

Status-A fairly common migrant, chiefly in the higher mountains, where it makes its appearance in July and August. Scott (1886, p. 43I) secured a specimen in the Santa Catalina Mountains, April ${ }_{4} 4$, I885, the only record I know of, of its occurrence in the spring. It has been found in the White Mountains, at Camp Grant and Camp Apache, in the Santa Catalina Mountains, and in the Huachucas.

162.

\section{Calothorax lucifer (Swainsen).}

LuCIFER HuM MingBird.

Synonym-Doricha inicura.

Status-One specimen, an adult female, taken by Henshaw (I $875^{b}$, p. $3^{8 I}$ ) at Fort Bowie, Angust 8,1874 . Not otherwise observed in Arizona.

163.

\section{Uranomitra salvini (Brewster).}

Salvin Hummingrimd.

Status-An inmature female, the second known specimen, was shot by H. WV. Marsden in the Huachuca Mountains, July 4, 1905. This bird is in the collection of L. B. Bishop (see Bishop, rgo6, p. 337).

164.

\section{Basilinna leucotis (Vieillot).}

WHITE-EARED HUMMINGBIRD.

Status-Rare summer visitant to some of the higher ranges of southeastern Arizona, reported from the Chiricahua, Santa Rita, and Huachuca mountains. There are published records of about half a dozen specinens taken in Arizona (see Fisher, 1894, p. 325; Swarth, 1904b, p. 19). It has not as yet been found actually breeding in the state, though it probably does so.

165.

\section{Cynanthus latirostris Swainsou.}

\section{Brond-BlLlen HummingBird.}

Synonyms-Circe latirostris; Iache latirostris.

Statıs-A summer visitant, reported from the Santa Catalina, Santa Rita, and Huachuca mountains, and from the Santa Cruz River west of the Patagonia Monntains. Probably most abt:ndant in the Santa Catalinas, where it is found along the streams from 3500 to 5000 feet. In the Huachucas it is of very rare oc- 
currence. Henshaw ( 1875 b, p. 380 ), records three specimens of this hummingbird "secured in the Chiricahua Mountains, at a point a few miles distant from old Camp Crittenden." As old Camp Crittenden is many miles distant from the Chiricahua Mountains, and in the foothills of the Santa Ritas, this would seen to be a mistake, the more so as in a previous report on the same collections (I875a, p. I62) mention is made of "three specimens secured in the Santa Rita Mountains near the borcier line." Bendire ( 1895, p. 228) explicitly states that the species is not yet recorded from the Chiricahua Mountains.

166.

\section{Platypsaris aglaiae albiventris (Lawrence).}

XANTUS BECARD.

Synonym-Platypsaris albiventris.

Status-Price ( 1888 b, p. 425) securerl a single specimen, a male bird, near the summit of the Huachuca Mountains, June 20, I888. This is the only record for Arizona, and for the United States.

167.

\section{Tyrannus verticalis Say.}

\section{WISTERN KINGRIRD.}

Status-A common sunmer visitant in the Lower Sonoran zone of southern and western Arizona. Fonnd in the valley of the Gila River, and along its more southern tributaries, and also along the Colorado River. Though not reported -from any part of the high mountainous, central portion of the state, its presence in the arid northeastern corner is attested by a July record from Keam Cañon (Fisher, 1903, p. 35).

I68.

Tyrannus vociferans Swainson.

\section{Cassin Kingbird.}

Status-Common summer visitant in parts of southeastern, and most of central and northern, Arizona. Breecis mostly in the Upper Sonoran zone, in places extending up into Transition. Reported from Nogales in January (Baird, I858, p. I74). Has not been found in the arid Jower Sonoran southwestern portion of Arizona.

I69.

Myiodynastes luteiventris Sclater.

Sulphur-bellied Flycatcher.

Status-A fairly common summer visitant in the higher mountain ranges of extreme southeastern Arizona. Has been found in the Sauta Rita Mountains (Henshaw, 1875a, p. I6I), the Chiricahua Mountains (Henshaw I875b, p. 346), and the Huachuca Mountains (Swarth, 1904b, p. 2I).

170.

Myiarchus magister magister Ridgway.

Arizona Cresten Fitycatchilir.

Synonyms-Myiarchus cooperi; Myiarchus mericanus cooperi; Mviarchus mexicanus magister. 
Status-A summer visitant in portions of southern and western Arizona, reported from the vicinity of Tucson and the Santa Cruz Valley (many records), the Gila Valley about Florence and Riversicle (Scott, r887, p. I7), and, the northernmost record, on the Big Sandy Creek, where Stephens (1903. p. 102) found it breeding in July, 1902. In southeastern Arizona, at least, its range coincides exactly with that of the giant cactus, in which it nests.

$17 \mathrm{~T}$.

Myiarchus cinerascens cinerascens (Lawrence).

ASH-THROATĘD FLyCATCHER.

Synonyms-Myiarchus mexicanus; Myiarchus crinitus var. cincrasiens; Myiarchus nuttingi.

Status-Abundant summer visitant, mostly in the Lower Sonoran zone, in southern and western Arizona, ranging north to Forts Apache and Whipple, and up the Colorado River the entire length of the state. It is also reported from Keam Cañon, in extreme northeastern Arizona, in July. Occurs as an occasional winter visitant, having been noted at Phoenix in December (specimen in Field Museum of Natural History), on the Gila River in Decemher (Baird, 1858, p. 179), and at Fort Mohave in January (Cooper, 1870, p. 316).

172.

\section{Myiarchus lawrencei olivascens Ridgway.}

Olivachous Fi.ycatcher.

Synonyms-Myiarchus lawrencci; Myiarchus lazurencci olie'aceus.

Status-Common summer visitant to a few mountain ranges of extreme southeastern Arizona. Most abundant in the Huachucas and Santa Ritas, but also reported from the Chiricahuas, the Whetstones, the Santa Catalinas (Scott, I887, p. 18, one specimen), and, doubtfully, from Fort Grant (Bendire, I895, 1). 270). Restricted almost entirely to brushy cañons of the Upper Sonoran zone.

173.

Sayornis sayus (Bonaparte).

SAY PHOEBE.

Synonym-T yraniula saya.

Status-Exceedingly common summer visitant of the plains and valleys throughout the state. Remains through the winter in southern Arizona: San Pedro River : Santa Catalina foothills (Scott, 1887, p. 18) ; and in the valley of the Colorado River: Yuma (Price, I899, p. 92).

174 .

Sayornis nigricans (Swainson).

Black PhöBe.

Synonym-Sayornis nigricans scmiatra.

Status-Resident in southern Arizona, irregularly distributed, and nowhere very common. Though resident in the region, it is locally migratory, moving up into the hills in summer (to about 6000 feet), and down to the lower valleys during the winter months. It has been traced north to Fort Apache (Henshaw, I875b, p. 347), Fort Verde (Coale, 1894, p. 215), to a point a few miles south of Fort Whipple (Coues, I866a, p. 60), and, along the Colorado River, where it is a winter visitant only, to Fort Mohave. Breeding records appear to be all from points in Upper Sonoran, up to the lower edge of Transition. 
175 .

Nuttallornis borealis (Swainson)

OLIVI-SIDED FI, CA'TCHER.

Synonym-Contopus borcalis.

Status-Common in summer from the Transition zone upward, in the higher mountains north of the Mogollon Plateau: recorded as breeding on the San Francisco, White, and Mogollon mountains. During the migrations it is quite generally distributed.

I 76.

Myiochanes pertinax pallidiventris (Chapman).

Couss Fiycatcher.

Synonyms-Contopus pertinax; Contopus pertinax pallidiaentris; Horizopus pertinax pallidiecntris.

Status-Common summer visitant in the Transition zone of the mountains of southeastern Arizona (Huachuca, Santa Rita, Santa Catalina and White mountains, Mount Graham, etc.), extending northward, in diminishing numbers, to the Mogollon Mountains, where it was found breeding at Baker's Butte (Mearns, I890a. p. 256) ; casually to Fort Whipple: I specinen, August 20, I864 (Coues, 1866a, p. 60).

177.

Myiochanes richardsoni richardsoni (Swainson).

WesterR WOOD PEIVEE.

Synonyms-Contopus richardsoni; Contopus airens richardsoni; Horizopus richardsoni; Contopus z'clici.

Status-Common in summer in Upper Sonoran and Transition throughout the state. During the migrations it is generally distributed.

178.

Empidonax difficilis difficilis Baird.

WESTERN FlyCatCHER.

Synonym-Empidonax flavizentris var. difficilis.

Status-A fairly common summer visitant, mostly in Transition, occurring in all the higher mountain ranges. Abundant and of general distribution during the migrations.

Empidonax trailli trailli (Audubon).

Traill Flycatcher.

Synonyms-Empidona.x pusillus; Empidona.t trailli var. pusillus.

Status-Probably fairly common in summer along most of the wooded streams in the lower valleys, though found actually breeding at but a few points : Tucson, Fort Whipple, San Pedro River, Santa Cruz River. During the migrations it is abundant and generally distributed.

I 8 o.

\section{Empidonax hammondi (Xantus).}

HAMAOND FLYCATCHER.

Status-A migrant, abundant and generally distributed throughout the state. It is not known to breed anywhere in Arizona. 
I 8 I.

Empidonax wrighti Baird.

\section{IVRIght Flycatcher.}

Synonym-Empidonax obscurus, part.

Status-A fairly common migrant, at least in eastern Arizona. I know of no atthentic instance of the breeding of this species in the state.

I 82.

\section{Empidonax griseus Brewster.}

Gray FLycatcher.

Sỵnonyms-Empidona.r obscurus, part; Empidonax aurightii, part.

Status-This species and the last (E: zurightii) have been so lopelessly confused in years past that it is impossible to allocate the various citations with accuracy, but it is certain that E. griscus has been many times mentioned under the name of the allied species. Both are migrants in Arizona, and both probably occur (E. griscus certainly) across the breadth of the state. Of neither form, however, is there any undoubted breeding record for Arizona. E. griscus is probably to be found in winter in the warmer parts of southeril Arizona, and along the lower Colorado River.

I83.

\section{Empidouax fulvifrons pygmaeus Coues.}

BUFF-BREASTED FLYCATCHER.

Synonyms-Empidonax pygmaeus; Mitrcpliorils pallescens; Mitrcphorus fulvifrons var. pallescens.

Status-A summer visitant, nowhere very conmon, but found in several of the monntain ranges of southeastern Arizona. It breeds mostly at the lower edge of the Transition zone, but is very locally distributed-thus it may be fairly common in one cañon, and almost unknown in an adjoining one. Has been found breeding in the Chiricahua, Huachıca, and Santa Rita mountains, and migrating birds have been taken at Forts Apache and Bowie. The subspecies was rlescribed from a specimen secured by Cones at Fort Whipple, which would seem to be its extreme northern limit. It has so far not been found in the Mogollon Mountains, which lie south of that point, but the fact of its breeding at Inscription Rock, New Mexico-close to the Arizona boundary (Henshaw, 1874, p. 128), points to the probability of its doing so in the Mogollons.

I 84 .

\section{Pyrocephalus rubinus mexicanus Sclater.}

VERMILION FLYCATCHER.

Synonyms-Pyroccphalus rubineus; Pyroccplialus mexicanus.

Status-An abundant resident along the wooded streams of southern and western Arizona, locally migratory, but occurrung in the warmer parts of the region throughout the year. In a general way it may be said to be restricted to the Lower Sonoran zone in the valleys of the Colorado and Gila rivers, and their tributaries. In central Arizona it extends north to Fort Verde (Coale, 1894. p. 218 ) ; casually to Fort Whipple (Cotres. I865, pp. I63, 538, I specimen) ; along the Colorado River, to the Big Sandy, Bill Williams River, and Ehrenberg (Stephens, 1903, p. 102), casulally to Fort Mohave (Cooper, 1870, p. 33.3; one seen May 24). In eastern Arizona does not range north of the Salt River. 
185

Camptostoma imberbe Sclater.

BEARDLESS FLYCATCHER.

Synonym-Ornithion imbcrbc ridgacayi.

Status-A rare summer visitant, known to occur in only a linited area in the Santa Cruz Valley, in the vicinity of Tucson. The conditions apparently required by the species, dense growths of tall timber, are met with in Arizona at so very few points, at the low altitudes frequented by the species, that its known range will probably not be greatly extended in the state.

I 86.

0tocoris alpestris leucolaema (Coues).

DESERT HORNED LARK.

Synonyms-(?) Otocoris alpestris, part; (?) Ercmophila cornuta, part: Eremophila alpestris var. chrysolaema, part; Otocory's arenicola, part; Otocoris alpestris arenicola, part; Otocoris alpestris cnthymia.

Status-Common winter visitant. There are numerous winter records of horned larks from the northern and central portion of Arizona, some of which are known to pertain to this subspecies, and others that probably do so. 187.

Otocoris alpestris adusta Dwight.

SCORCHED HORNED LARK.

Synonyms-Eremophila alpestris chrysolaema, part; (?) Otocoris alpestris chrysolaema, part; Otocoris alpestris aphrasta.

Status-Common resident on the plains of extreme southeastern Arizona, from the west side of the Santa Rita Mountains (Swarth, 1905a, p. 79) east to Iiort Bowie (Bendire, 1895, p. 345). North to Tucson and Oracle. Other points of record are Fort Huachuca, San Pedro River, Greaterville, Willow Spring, Sulphur Spring, and Wilcox.

188.

Otocoris alpestris pallida Dwight.

SONORA HORNED LARK.

Synonyms-Otocoris alpestris arenicola, part; Otocoris alpestris leucansiptila.

Status-Resident on the desert plains of extreme southwestern Arizona, and probably northward in the Colorado Valley to southern Nevada (cf. Oberholser. Igo2, pp. 864-866). I 89.

\section{0tocoris alpestris occidentalis McCall.}

MONTEZUMA HORNED LARK.

Synonyms-Eirmophila cornuta, part; Ercmophila alpestris chrysolacme, part; Otocoris alpestris adusta, part; Otocoris alpestris arenicola, part; (?) Otocoris alpestris actia.

Status-Breeding, and perhaps resident, in northern and central Arizona, north of the Mogollon Divide, and west to Fort Whipple (Cones, I866a, p. 79). There are breeding records from San Francisco Mountain, Fort Vercle, and the I.ittle Colorado River (Oherholser, 1902, p. 855). In the Mogollon Mountains it has been found breeding 11 p to 10,000 feet (Mearns, I890a, p. 256). Localities at which it has been found at other seasons are Pima County, Wilcox, San Pedro River, and Fort Huachuca. 
190.

Pica pica hudsonia (Sabine).

MAGPIE.

Sỹnonyms-Pica hudsonica; Pica caudata var. hudsonica.

Status-Secured by Kennerly (I856, p. Io) on the Little Colorado River. Recorded by Henshaw ( 1874, p. I23) from the Rio Puerco, at a point sixty miles west of Wingate, New Mexico, and hence well within the Arizona boundary. Not otherwise recorded from the state.

IgI. Cyanocitta stelleri diadenata (Bonaparte).

LONG-CRESTED JAY.

Synonyms-Cyanocorax stelleri; Cyanocitta macrolopha; Cyanura macrolopha; Cyctnura stellcri var. macrolopha; Cyanocitta steileri macrolopha, Cyanocitta sielieri.

Status-A common resiclent of the mountains throughout the state from the Transition zone upward. In northern Arizona it ranges west as far as the Grand Cañon of the Colorado (Merriam, I 890, p. 39), and the Hualpai Mountains (Stephens, I003, p. I02). Though resident at high altitudes it occasionally wanders into the lowiands, far from the mountains, as observed at Sacaton in Novenber, IOIo, by Gilman (igi Ia, p. 35).

192.

Aphelocoma woodhousei (Baird).

WOODHOUSE JAY.

Synonyms-Cyanocorax californica; Cyanocitta californica; Cyanocitta woodhouseii; Cyanocitta floridana var. woodhousei; Aphclocoma floridana var. woodhousei.

Status-Fairly common resident, mostly in Upper Sonoran, and occurring in favorable localities throughout the state. Has not been observed anywhere in southwestern Arizona, west of Sacaton, nor along the Colorado River below the Grand Cañon.

I93.

Aphelocoma sieberi arizonae (Ridgway).

Arizona Jay.

Synonyms-Cyanocitta sordida; Cyanocitta ultramarina var. arizonae; Aphclocoma sordida arizonac.

Status-An abundant resident of the live oak regions of the mountain ranges of southeastern Arizona. It has been reported from the Santa Rita, Chiricahua, Santa Catalina, Huachuca, Dragoon, Whetstone, and Rincon mountains, Mount Graham, and from a point thirty miles south of Camp Apache, apparently the northern linit of the species.

I94.

Perisoreus canadensis capitalis Ridgway.

Rocky Mounitain Jay.

Status-Reported only from the White Mountains, where it is apparently a not uncommon resident (Henshaw, I875b, p. 339; Mearns, I890a, p. 256). 
195.

Corvus corax sinuatus Wagler.

AMERICAN RAVEN.

Synonyms-Corvus corax; Corvus splendens; Corvus cacalotl; Corzus carnivorus; Corus corax carnivorus.

Status-Apparently to be found throughout the year in nearly all parts of Arizona. It appears to breed mostly in the ligher mountains, though it is a conımon sight to see ravens in summer, probably non-breeding birds, almost anywhere in the lower valleys.

196.

\section{Corvus cryptoleucus Couch.}

\section{WHITE-NECKED RAVEN.}

Status-Has been observed only in the extreme southeastern corner of Arizona, in Cochise County, and west and north to Oracle, Tucson, and the valley of the Santa Cruz River. It is restricted wholly to the Lower Sonoran zone, and is mainly a summer visitant to the region. Some remain throughout the winter in favorable localities: Wilcox, November (Bailey, I903, p. 87) ; San Pellro River, February (Willard, I9IOc, p. I IO).

I97.

\section{Corvus brachyrhynchos hesperis Ridgway.}

WESTERN CROW.

Synonym-Corous americanus.

Status-A very uncommon species in most parts of Arizona. I know of but four records for the state; at Fort Apache in November (Henshaw, 1875a, p. I60); in the Santa Catalina Mountains and at Mineral Creek during the migrations (Scott, I887, p. 2I); breeding commonly in the Mogollon Mountains (Mearns, I89oa, p. 256) ; and uncommon in the vicinity of San Francisco Mountain (Merriam, 1890, p. 94).

198.

Nucifraga columbiana (Wilson).

\section{Clarke Nutcracker.}

Synonym-Picicorvus columbianus.

Status-Recorded as breeding in the higher parts of San Francisco Mountain, where it is common (Merrianı, I890, p. 94). Adults seen feediris fullgrown young in the Santa Catalina Mountains, May 21, 1904 (F. C. Willard, MS). During the migrations and in winter, it has heen noted at irregular intervals at scattered points: Fort Whipple, White Mountains, Huacluca Mouritains, etc., and even from the desert region at Sacaton, on one occasion, October I 7, I9Io (Gilman, I9I Ia, p. 35).

I99.

\section{Cyanocephalus cyanocephalus (Wied).}

PIÑON JAY.

Synonym-Gymnokitta cyanocephala.

Status-A resident about Fort Whipple, according to Coues ( 1866 a, p. 9I). It has also been reported as breeding in the piñon belt of San Francisco Mountain (Merriam, I890, p. 94), and in the vicinity of Williams (Wetmore, I908, p. 380 ). It is an erratic visitant to other parts of Arizona (Huachuca Mountains, Santa Catalina Mountains, Gila River, Keam Cañon, etc.). 
200.

Molothrus ater obscurus (Gmelin).

DivarF Cowbird.

Synonyms-Molothrus pecoris; Molothrus pecoris var. obscurus; Molothrus obscurus; Molothrus atcr.

Status-Found in the greatest abundance in the valleys of the Colorado and Gila rivers, and their tributaries, and up into the foothills of the adjacent mountains. Most abundant as a summer yisitant, and reported from many localities, north to the Mogollon Mountains (Mearns, I890a, p. 257), Fort Whipple (Coues, r866a, p. 90), and Fort Mohave (Mus. Vert. Zool.). Remains throughout the winter on the lower Colorado River. The only winter record I know of outside of the Colorado Valley is of a singie specimen taken by Bendire ( 1895 . p. 44) on Rillito Creek, near Tucson, January 24, 1873.

201.

Tangavius aeneus aeneus (IVagler).

BRONZED CowBIRD.

Synonym-Tangavius acneus incolucratus.

Status-An occasional sumner visitant in the hot valleys of extreme southern Arizona. Seen in the vicinity of Tucson during the summer of 1909 , from April to September (Visher, I909, p. 307; 1910, p. 210) ; and at Sacaton, also in the summer of rgog (Gilinan, rgio, p. 46).

202.

Xanthocephalus xanthocephalus (Bonaparte).

YELLOW-HEADED BLACKBIRD.

Synonyms-Agelaius xanthocephalus; Xanthocephalus icteroccphalus; Xanthocephalus longipes.

Status-Reported as breeding in the Mogollon Mountains (Mearns, r890a, p. 257) and at Fort Whipple (Cones, r866a, p. 91). It winters commonly south of the Gila River (Tucson, Fort Huachuca, etc.), and along the Colorado River from Fort Mohave southward.

203.

Agelaius phoeniceus sonoriensis Ridgway.

SONORA RED-IVINGED BLACKBIRD.

Synonyms-Agelaius gubernator, part; Agclaius phocniceus, part; Agelaius phoeniceus longirostris.

Status-A common resident in the valley of the Colorado River, at least. Its manner of occurrence in other parts of Arizona has yet to be determined.

204 .

Agelaius phoeniceus fortis Ridgway.

NortIIERN RED-WINGED BL.ACKBIRD.

Status-According to Ridgway (1902, p. 339) this subspecies occurs during the migrations as far south as "Arizona (Fort Verde, December, February: Big Chino Valley, March)."

205 .

Agelaius phoeniceus neutralis Ridgway.

San Diego Red-iwinged Blackeird.

Synonyms-(?) Agclaius phocniccus, part; (?) Agclaius gubcrnator, part; Agelaius phocniceus sonoriensis, part. 
Status-The status of the red-winged blackbirds of Arizona is as yet unsettled. The type of $A$. p . sonoriensis came from Fort Grant, in southeastern Arizona,* but breeding birds examined from the San Pedro River, in the same general region, are $A$. p. neutralis. It may be that one form (sonoriensis) breeds along the Colorado River and the lower Gila, these river valleys being the only portion of the Lower Sonoran zone which is adapted to the species; and that the other (ncutralis) occupies the higher Upper Sonoran zone in northern and eastern Arizona. At any rate some form of the red-winged blackbird breeds, in suitable localities throughout the state. Alcng the Colorado River, and in the valleys of southern Arizona, they are to be found the year through; in the winter months the several varieties possibly occur together in the same places.

206.

\section{Sturnella magna hoopesi Stone.}

TFXAS MEADOWLARK.

Synonym-Sturnclla magna me.ricana.

Status-Known to occur along the United States-Mexican boundary line, at least in eastern Arizona, specimens having been taken at Camp Crittenden, Fort Huachuca and Calabasas; also reported from the vicinity of Williams, in the northern part of the state (Wetmore, rgo8, p. 38I).

207.

\section{Sturnella neglecta Audubon.}

\section{WESTERN MEADOWLARK.}

Synonym-Sturnella magna neglecta.

Status-Resident throughout the state, but irregularly and locally distributed, and, for the most part, not very common. In the Mogollon Mountains, ranges up to 10,000 feet (Mearns, I890a, p. 257). In southern Arizona occurs in the Lower Sonoran valleys only.

208.

\section{Icterus parisorum Bonaparte.}

\section{SCOT'T ORIOLE.}

Status-An abundant migrant and fairly common summer visitant in parts of southeastern and central Arizona. It is distinctly a bird of the Upper Sonoran zone, known to breed in southern Arizona, in the foothill regions of the Huachuca, Santa Rita, Santa Catalina, Rincon, Quijotoa and Whetstone mountains; doubtless it is to be found in other ranges in the same general region which have not been reported upon. Has also been found in summer at Oracle (Rhoads, I892, p. I 20) and at Beale Spring in western Arizona (Stephens, I903, p. I02). Has not been found in southwestern Arizona, nor at any point along the Colorado River, except for one bird doubtfully identified at Fort Mohave (Cooper, I87o, p. 276).

* According to the A. O. U. Check.List, 1910 ed., p. 233. Ridgway (Birds North and Middle America, II, 1902, p. 337) gives it as Mazatlan, western Mexico. 
209 .

Icterus cucullatus nelsoni Ridgway.

\section{Arizona Hooded Oriole.}

Synonym-Ictcrus cucullatus.

Status-Common summer visitant of the Lower Sonoran zone in southern Arizona, ranging north to Fort Grant in the east (Coues, I868, p. 84), and to the Big Sandy and Bill Williams River, in the western parts of the state (Stephens, I903, p. I03). Found breeding near Pilot Knob, on the California side of the Colorado River (Mus. Vert. Zool.).

210.

Icterus bullocki (Swainson).

\section{Bullock Oriole.}

Status-Summer visitant, found in suitable localities throughout the state. In southern Arizona its range overlaps that of $I$. c. nelsoni, but it is much less abundant than that species. Points of record are all in the Upper arid Lower Sonoran zones; it has not been found in the high central plateau region. Breeds commonly along the Colorado River, at least as far up as The Needles (Mus. Vert. Zool.).

2II.

\section{Euphagus cyanocephalus (Wagler).}

\section{BREWER BlackBIRD.}

Synonyms-Scolccophagus ferrugincus; Scolecophagus cyanocephalus.

Status-An abundant migrant and winter visitant throughout southern Arizona. There are but few definite breeding records for any part of the state. It is known to breed commonly in the Mogollon and San Francisco mountains . (Mearns, I890a, p. 257), and Coues (r866a, p. 90) speaks of it as a summer resident at Fort Whipple. Otherwise it has been observed in all parts of Arizona as a transient or as a winter visitant.

212.

Hesperiphona vespertina montana Ridgway.

WESTERN EVENING GROSBEAK.

Synonyms-Hesperiphona vespertina; Coccothraustes vespertina; Coccothraustes vespertina montana.

Status-Breeds in the high mountains of central Arizona: San Francisco Mountain (Merriam, I890, p. 95), White Mountains (Swinburne, I888a, p. I13), Mogollon Mountains (Mearns, I8goa, p. 246); occasionally in some of the ranges farther south; Santa Catalina and Huachuca mountains (Willard, I9Ioa, p. 6o). During the migrations and in winter it is reported from various scattered localities: Huachuca Mountains, Santa Catalina Mountains, Fort Verde, and Fort Apache.

213.

Carpodacus purpureus californicus Baird.

California Purple Finch.

Status-The only Arizona record is that of Scott (1887, p. I96), who found the species abundant in the Santa Catalina Mountains from November, 1885 , to February, i 886. 
214.

Carpodacus cassini Baird.

Cassin Purple Finch.

Synonyms-Carpodacus purpurcus; Carpodacus pileatus.

Status-Reported as a resident in the pine belt of the Mogollon Mountains (Mearns, 1890a. p. 258). During the migrations and in winter it is quite generally distributed: Fort Whipple (Coues, i866a, p. 80); Pueblo Creek and Aztec Mountains, January (Kennerly, I859, p. 27) ; Bill Williams Mountain, March (Wetmore, 1908, p. 38I). In southern Arizona as a winter visitant only, seldom descending into the low valleys, but common in the higher mountains: Santa Catalina Mountains and Tucson (Scott, 1887, p. 197); Dragoon Mountains (Osgood, I903, p. I3I.) : Huachuca Mountains (Swarth, I908, p. I I3).

2 I 5 .

Carpodacus mexicanus frontalis (Say).

House Finch.

Synonyms-Fingilla frontalis: Carpodacus familiaris; Carpodacus californicus: Carpodacus cassini, part; Carpodacus mericanus obscurus: Carpodacus frontalis.

Status-Fairly common resident throughout the state, though locally migratory. Breeds below Transition: restricted to the warmer valleys in winter. Occurs nowhere in Arizona in such large numbers as are seen on the Pacific coast of California.

216.

Loxia curvirostra stricklandi Ridgway.

Mexican Crossbill.

Synonyms-Curvirostra amcricana; Loxia curvirostra var. amcricana; Loxia curirirostra mexicana.

Status-Breeds from the Transition zone upwards in the mountains of the high plateau region: Wiiliams, breeding (Wetmore, I908, p. 382): Mogollon Mountains (Mearns, I8goa, p. 258) : possibly in some of the more souther!1 ranges also. Noted at various scattered points (usually at high altitudes) during the migrations, and in the winter: San Francisco Mountain, Grand Cañon, Mount Graham, Huachuca, Santa Catalina and Chiricahua mountains.

217.

Passer domesticus (Jinnaens).

ENGLish SPARROW.

Status-Common at the present time in most of the larger towns and along the railroads. The species rcached Tucson in 1903. and Tombstone in r904 (Howard, 1906, p. 67). Also recorded from Benson, Flagstaff, Williams, Phoenix and Mellen.

2 I 8 .

\section{Astragalinus tristis pallidus (Mearns).}

\section{PALE GoldFinch.}

Synonyms-Chrysomitris tristis; Spinus tristis; Spimus tristis pallidus.

Status-From the paucity of records this is evidently a rare species in Arizona. Henshaw ( 1875 a, p. I 58 ) cities Bendire as having observed it at Tucson; Scott ( 1887 , p. I97) secured six specimens in the Santa Catalina Mountains in December, I885, and February, I886; and Mearns ( I890a, p. 244) found it, apparently abundant, at Fort Verde in winter and spring. 
219.

Astragalinus psaltria hesperophilus Oberholser.

GREEN-BACKED GOLDFINCII.

Synonyms-Chrysomitris psaltria; Chrysomitris mexicana; Chrysomitris mexicanus var. arizonae; Chrysomitris psaltria var. arizonae; Astragalinus psaltria arizonae; Astragalinus psaltria; Spinus psaltria; Spinus psaltria arizonae.

Status-Occurs below Transition throughout the state. In northern Arizona it is a summer visitant only, as is the case in the mountain ranges of the south as well. In the lower valleys of southern Arizona it occurs irregularly throughout the year. Noted as a common resident, and found breeding, along the Colorado River, between Needles and Yuma (Mus. Vert. Zool.).

220 .

\section{Astragalinus lawrencei (Cassin).}

LAWRENCE GOLDFINCH.

Synonyms-Chry'somitris lacurencei; Spimus lairencci.

Status-Winter visitant, probably regularly, though in small numbers, to the Colorado Valley; of rare and irregular occurrence elsewhere. Cones ( I866a, p. 83) noted it at Fort Whipple, and Cooper (I870, p. I7I) at Fort Mohave during the winter months.

Its ohscrvation on the Colorado River at Riverside Mountain. March I7, I9 Io (Mus. Vert. Zool.), although on the California side of the stream, is confirmatory of its probably regular occurrence in this region in winter. Scott ( 1887, p. 199) recorded a specimen taken by Herbert Brown at Tucson, February 28,1885 , and Price $(1899$, p. 92$)$ reported it from the vicinity of Yuma in December. These are the only records.

$22 \mathrm{I}$.

\section{Spinus pinus (Wilson).}

\section{Pine Siskin.}

Synonym-Chrysomitris pinus.

Status-Common resident in the high mountains of the platean region: San Francisco Mountain, breeding (Merriam, 1890, p. 95) ; Mogollon Mountains, resident (Mearns, I890a, p. 258) ; breeding at least as far south as Mount Grahan (Henshaw, I875a, p. I58). Conmon in winter in the higher ranges of southern Arizona: Chiricahua, Santa Catalina and Huachuca mountains; and of occasional occurrence in the valleys during the migrations: San Pedro River, April (Swarth, I904b, p. 37).

222.

\section{Calcarius ornatus (Townsend).}

\section{Chestnut-COl-Lakęid Longspur.}

Synonyms-Plectrophanes melanomus: Plectrophanes ornatus.

Status-Abundant migrant, and. less commonly, a winter visitant in extrenie eastern Arizona, reported from St. Johns, Fort Grant, Fort Huachuca, Fort Bowie, Sulphur Spring Valley, etc.; occasionally straggling farther westward: Santa Catalina Mountains, November I I, I885; Fort Whipple, I specimen, October 17, 1864: Sacaton, October 25, 1909. 


\section{Synonym-Plectrophanes maccormii.}

Status--Occurs in the same manner as Calcarius ornatus, and over practically the same territory in castern Arizona. It is more irregular in its appearance and usually not as abundant as the Chestnut-collared Longspur. Reported from Fort Bowie, Fort Apache, St. Johns, Sulphur Spring Valley, Fort Huachuca, and Fort Lowell.

WESTERN VESPER SPARROW.

Synonyms-Zonotrichia graminea; Pooecetes gramineus.

Status-The only breeding records are from the Mogollon and San Francisco mountains (Mearns, I890a, p. 259), and Fort Whipple (Coues, r866a, p. 84). It is exceedingly abundant in winter and during the migrations, throughout southern Arizona and along the valley of the Colorado River.

225.

\section{Passerculus sandwichensis alaudinus Bonaparte.}

\section{Western Savannah Sparrow.}

Synonyms-Passcrculus savanna; Passerculus alaudinus, part; Ammodramus sandrichensis alaudinus.

Status-A migrant and winter visitant in the valleys of southern Arizona and along the Colorado River. There are but few records of the occurrence of the species, and it does not appear to have been found anywhere in abundance.

226.

\section{Passerculus sandwichensis nevadensis Grinnell.}

Nevada Savannah Sparrow.

Synonym-Passerculus alaudinus, part.

Status-The record by Coues (I866a, p. 84) of the occurrence of a Savannah sparrow as a common summer visitant at Fort Whipple probably pertains to this subspecies. Three specimens taken on the Colorado River, two near the mouth of Bill Williams River, March I3, and one five miles north of Laguna, April 22, I9Io (Mus. Vert. Zool.).

\section{Passerculus rostratus rostratus (Cassin).}

LARGE-BILlED SPARROW.

Status-"Casual in Arizona". (A. O. U. Check-List, 1910, p. 255). This record was based on a specimen taken August I5, I902, at Yuma, by Herbart Brown, and sent to the Biological Survey for identification, according to information received by me from Mr. W. W. Cooke.

228.

\section{Ammodramus bairdi (Audubon).}

\section{BAIrd SPArRow.}

Synonyms-Centronyx bairdi; Passerculus bairdi; Coturniculus bairdi.

Status-Common migrant on the open grassy plains of the extreme southeastern corner of the state, reported from Camp Grant, Camp Crittenden, and the vicinity of the Huachuca Mountains. A few probably remain through the winter in favorable localities. 
229.

Ammodramus savannarum bimaculatus Swainson.

Western Grasshopper Sparrow.

Synonyms-Ammodramus passerinus; Coturniculus passerimus; Coturniculus passerinus var. perpallidus; Ammodramus savannarum perpallidus; Ammodromus savannarum; Coturniculus sazannarum bimaculatus.

Status-Reported only from western and southern Arizona. Probably breeds in parts of southern Arizona, at least, as Henshaw (1875b, p. 257) secured very young birds in the Sonoita Valley, at the southeastern base of the Santa Rita Mountains; while there is a specimen recorded as taken at Los Nogales in June (Baird, 1859, p. 15). It has been taken at Bill Williams River in February (Kennerly, 1859 , p. 28), and in the Santa Catalina Mountains in January (Scott, I887, p. 199).

2.30 .

Chondestes grammacus strigatus Swainson.

W Listeri Lark Sparrow.

Synonym-Chondestes grammaca.

Statıs--Common summer visitant in suitable localities throughout Arizona. Breeding rccords are from points in Lower and Upper Sonoran, up to the lower edge of Transition; Santa Catalina Mountains up to 5000 feet (Scott, I887, p. 199); Mogollon and San Francisco mountains, summer resident (Mearns, I890a, p. 259); Huachuca Mountains, summer visitant (Swarth, 1904b, p. 39); etc. Locally migratory; during the winter months restricted mainly to the warmer valleys of the southern and western parts of the state: San Pedro River, February (Willard, I910c, p. I10); Tucson, resident (Scott, 1. c.); Yuma, December (Price, 1899, p. 92).

23 I.

Zonotrichia leucophrys leucophrys (Forster).

White-Crowned Sparrow.

Status-A common migrant throughout Arizona, usually in company with Zonotrichia l. gambcli. Possibly a few remain through the winter in parts of southern Arizona, though there is no authentic instance on record. Mearns (I890a, p. 259) found the species at the base of San Francisco Mountain in June, "apparently breeding". It has not otherwise been found in the summer. Noted as a transient in the Colorado Valley between Needles and Yuma (Mus. Vert. Zool.).

232.

Zonotrichia leucophrys gambeli (Nuttall).

INTERM EDIATE SPARROW.

Synonyms-Zonotrichia leucophrys, part; Zonotrichia gambclii; Zonotrichia leucophrys intermedia; Zonotrichia intermedia.

Status-Abundant migrant throughout the state. Winter records are all from points south and west of the Mogollon Divide; Colorado River Valley from Fort Mohave southward, Fort Whipple, San Pedro River, etc., where it is common during the winter months. 
WESTERN TREE SPARROW.

Synonyms-Spizclla canadensis; Spizclla monticola.

Status-Kennerly ( 1859 , p. 29) found this species in December on the Little Colorado River, while Henshaw ( $1875^{a}$, p. I59) reported it, on the authority of Bendire, as of occasional occurrence in winter in the vicinity of Tucson. These are the only records for the state.

234.

Spizella passerina arizonae Coues.

Westeirn Chipping Sparrow.

Synonynı-Spizella socialis; Spizclla socialis arizonac.

Status-Common summer visitant in parts of central Arizona. Found breeding at Fort Whipple (Cones, 1866a, p. 87), and on the Mogollon and San Francisco mountains (Mearns, I890a, p. 259). In southern Arizona it is a very abundant migrant, and in the warmer valleys a winter visitant also. Observed in some numbers along the Colorado River, from The Needles southward in February, March, and April; seen at Potholes, May I, under conditions possibiy indicative of breeding (Mus. Vert. Zool.). Two specimens taken by Cooper at Fort Mohave, December 24, I860 (in Mus. Vert. Zool.).

235 .

Spizella pallida (Swainson).

Clay-Colored Sparrow.

Synonym-Spizella pusio.

Status-Henshaw (1875b, p. 278) secured specimens at Camp Crittenden in September; and Scott ( 1887, p. 200) met with the species at Mineral Creek in March, October, and November. These seem to be the only Arizona records. It is highly probable that Cooper's ( $186 \mathrm{~T}$, p. I22) reference to Spizclla palida as common in April in the vicinity of Fort Mohave, really pertains to S. breceri.

236.

Spizella breweri Cassin.

BrEwir Sparrow.

Synonyms-Spizella pallida, part: Spizclla pallida var. brciveri.

Status-Reported as breeding at Fort Whipple (Couses, I866a, p. 87), and in the Huachuca Mountains (Willard, I908b. p. 206), and as probably breeding on the Desert of the Little Colorado (Merriam, I890, p. 96). In the northerr. and central parts of the state it is a summer visitant only, but in the lowlands of southern Arizona it remains in numbers throughout the winter, as is also the case along the Colorado River from The Needles southward (Mus. Vert. Zool.).

237 .

Spizella atrogularis (Cabanis).

Bi.ACK-CHINNED SPARROW.

Synonym-Spizclla evura.

Status-There are but few records of the occurrence of this species in Arizona. Found at Fort Whipple as a rare summer visitant but common migrant (Coues, I866a, p. 87) ; specimens secured at Mineral Creek in October, and in the Santa Catalina Mountains in February (Scott, I887, p. 200) : found breeding in the Hualpai Mountains at 6000 feet (Stephens, 1903, p. 103); and noted on one occasion in the Huachuca Mountains in April (Swarth, 1904b, p. 40). 
238. Junco hyemalis hyemalis (Linnaeus).

Slate-coloreid Junco.

Status-Has been reported in winter from many scattered points: Fort Whipple, Fort Molnave, Santa Catalina Mountains, Huachuca Mountains, IVilliams, etc. Never at all common, but usually found in flocks composed of the various species of juncos wintering in the region.

239 .

\section{Juneo montanus Ridgway.}

Montana Junco.

Synonym-Junco hyemalis montanus.

Status-"In winter south to Arizona (Tucson)" (Ridgway, I90I, p. 290). I know of no other record.

240.

Junco oreganus thurberi Anthony.

SiERRA JUNCO.

Synonyms-Junco oregonus, part: Junco hycmalis thurbcri.

Status-As this species has been found in abundance in winter in the Huachua Mountains, of extreme southeastern Arizona (Swarth, 1904b, p. 40) it will doubtless prove to be a common winter visitant in all suitable places west of that point. There is record of a specimen from Fort Whipple (Ridgway. I90I, p. 288). There is a specimen in the Museum of Vertebrate Zoology (no. 4I43) taken by J. G. Cooper at Fort Moliave, December 24, I860.

241 .

Junco oreganus shufeldti Coale.

SHUFELDT Juxco.

Synonyms-Struthus oregonus; Junco oregonus, part; Junco hycmalis orcgonus; Junco connectens; Junco hycmalis connectens.

Status-A common winter visitant reported from all parts of Arizona, but generally favoring the mountains and the foothill regions, rather than the more open valleys. Nearly all of the numerous records of Junco oregonlis in Arizona are considered by Ridgway (ICOI, p. 285) to pertain to this subspecies.

242.

Junco mearnsi Ridgway.

PINK-SIDED JUNCO.

Synonyms-Junco annectens: Junco ridgreayi, part: Junco hycmalis mearnsi.

Status-A common winter visitant in northern and eastern Arizona, reported from the following localities: Fort Whipple, Prescott. Williams, Santa Catalina Mountains, Huachuca Mountains, and Sulphur Spring Valley.

243.

Junco caniceps (Woodhouse).

GRAY-HEAdED Junco.

Synonyms-Struthus caniceps, part: Junco cincrcus caniccps: Junco ridga'ayi, part: Junco phaconotus caniceps.

Status-A common winter visitant in the Upper Sonoran and Transition zones at least as far north as Fort Whipple. Reported from numerous localities: Fort Whipple, Williams, and the Chiricahua, Santa Cataina, Huachuca, Dragoon and Whetstone mountains. 
244.

Junco phaeonotus palliatus Ridgway.

Arizona Junco.

Synonyms-Junco cincreus; Junco cincreus palliatus.

Status-Common resident of the Transition zone of eastern Arizona, from Mount Graham southward. Reported from the Gralıam, Santa Catalina, Santa Rita, Chiricahua, Pinal, Huachuca, and Whetstone mountains. It is strictly a resident in the higher mountains, there being apparently not even a local migration downward into the valleys during the winter months.

245 .

Junco phaeonotus dorsalis Henry.

RED-BACKED JunCO.

Synonyms-Struthus caniceps, part; Junco cincreus dorsalis; Junco dorsalis.

Status-Resident in the high mountains of northeastern Arizona, reported from San Francisco Mountain, Grand Cañon of the Colorarlo, White Mountains. and Mogollon Mountains.

246.

Amphispiza bilineata deserticola Ridgway.

DESER'T SPARROW.

Synonyms-Poospiza bilincata; Amphispiza bilineata.

Status-Common summer resident in the arid Lower Sonoran plains, of southern and western Arizona, north to Forts Verde, Whipple, and Mohave; also reported in summer from the Desert of the Little Colorado and Keam Cañon, in northeastern Arizona. Remains through the winter in some of the warmer southern valleys.

247.

Amphispiza nevadensis nevadensis (Ridgway).

Sage Sparrow.

Synonyms-Poospiza belli; Poospiza belli, var. nevadensis; Amphispiza belli nevadensis; Amphispiza belli cincrea.

Status-A fairly common winter visitant, reported from various parts of the state: Little Colorado River, December (Kennerly, I859, p. 29) ; Fort Whipple (Coues, I866a, p. 86) ; San Pedro River and Tucson, December (Scott, I887, p. 203) ; Fort Huachuca, winter (Fisher, I904, p. 80). Price's ( 1899, p. 93) record of Amphispiza belli cinerea? at Yuma in midwinter also probably pertains to this species. As young in the spotted plumage were taken at Flagstaff, on the Desert of the Little Colorado, and at the Grand Cañon of the Colorado (Merriam, I89o. p. 96), the species may breed in this general region.

248.

\section{Peucaea botterii (Sclater).}

Bot'TERI SPARROW.

Synonyms-Pcucaea cassinii, part; Pencaea aestivalis var. arizonae; Pencaea arizonae.

Status-Found only in the Lower Sonoran valleys of southeastern Arizona; reported north to Camp Grant (Henshaw, i874, p. I 8 ), west to the valley of the Santa.Cruz River (Stephens, I885, p. 226). Possibly resident, but all the records thus far published are of observations made during the summer months. 
249.

Peucaea cassini (Woodhouse).

Cassin Sparrow.

Synonym-Zonotriclia cassini.

Status-Locally abundant during the summer in the Lower-Sonoran valleys of southeastern Arizona, recorded from over practically the same area as that occupied by Peucaca botterii. Ranges north to Fort Grant (Henshaw, 1875b, p. 285), west as far as the Santa Cruz Valley (Stephens, I885, p. 226). I know of no instance of its having been found actually breeding, though taken throughout the summer, nor do I know of any midwinter record.

250.

\section{Aimophila carpalis (Cones).}

RuFous-iwinged Sparrow.

Synonym-Peucaca carpalis.

Status-Found only in southeastern Arizona, where it has been reported from Tucson, Fort Lowell, the foothills of the Santa Catalina Mountains (up to 4500 feet), and the Santa Cruz Valley. Probably resident, as specimens have been taken in January as well as in midsummer.

$25 \mathrm{I}$.

Aimophila ruficeps scotti (Sennett).

Scotri Sparrow.

Synonyms-Pcucaca ruficeps boucardi; Peucaca homochlamys; Peucaea ruficeps scotti.

Status-Common resident of the Upper Sonoran foothills of southeastern Arizona. Occurs in all the ranges sotith of Camp Apache (Henshaw, 1875b, p. 289), and west of the Santa Cruz River: Santa Catalina, Santa Rita, Chiricahua, Huachuca mountains, etc. Has also been found in the Grand Cañon of the Colorado, below 4000 feet, and on the Desert of the Little Colorado (Merriam, I89o, pp. 40, 97), in extreme northern Arizona.

252.

Melospiza melodia saltonis Grinnell.

Desert Song Sparrow.

Synonyms-Zonotrichia fallax; Melospiza fallax; Mclospiza melodia; Mclospiza fasciata fallax; Mclospiza cincrea falla.t; Mclospiza melodia fallax.

Status-Common resident of the Lower Sonoran river valleys. Occurs along the Colorado River for nearly its entire extent in the state, being reported from below Yuma and as far up the river as Moencopie in northeastern Arizona (Merriam, I890, p. 97). Occurs in suitable localities (which are not numerous) in southern Arizona, along the valley of the Gila River and its tributaries (Santa Cruz River, San Pedro River, etc.). I know of no song sparrow records from the high plateau region of central Arizona.

253. Melospiza melodia fallax (Baird).

Mountain Song Sparrow.

Synonyms-Melospiza melodia var. hecrmanni; Melospiza fasciata montana; Mclospisa melodia montana. 
Status-A fairly common winter visitant or transient. Specimens have been taken as follows: San Pedro River and Tucson, winter (Scott. 1887, p. 204); Sulphur Spring Valley, March (Osgood, I903, p. 149) ; San Francisco Mountain, August (Merriam, I890, p. 97) ; and Colorado River at Needles, mouth of Bill Williams River, and Riverside Mountain, February and March, 19lo (Mus. Vert. Zool.). Probably a migrant in northern Arizona, and a winter visitant along the lower Colorado River, and in the southern valleys.

254 .

Melospiza melodia merrilli Brewster.

Márrill Song Sparrow.

Status-Recorded from Apache, Arizona, in winter (Ridgway, Igor, p. 36 I).

255 .

\section{Melospiza lincolni lincolni (Audubon).}

Lincoln Sparrow.

Synonym-Pencaea lincolni.

Status-Of fairly common occurrence as a migrant in suitable places; generally distributed and reported from many scattered localities. Probably remains in the valley of the lower Colorado River throughout the winter, though there is no definite clata establishing this as a fact. Possibly a winter visitant in othe: parts of southern Arizona also. Found on the Bili Williams River in Febrliary (Kennerly. 1859, p. 29).

256.

Passerella iliaca schistacea Baircl.

\section{Slate-coloreid Fox Sparrow.}

Synonym-Passerclla tor'nsendi schistacea.

Status-A rare migrant and winter visitant. There are published records of but four specimens from Arizona: one from a point forty miles south of Camp) A pache, September I, 1873 (Henshaw, I875b, p. 293) ; one from 'Tucson, February, 1880 (Brewster, 1882, p. 197): one from San Francisco Mountain, September 29, 1889 (Merriam, I890, p. 97) ; and one from the Huachuca Mountains. November 20, I894 (Fisher, 1904. p. 8I).

257.

Pipilo maculatus montanus Swarth.

Moun'tain TOWHEF.

Synonyms - Pipilo arctica: Pipilo crythroplutizalmus: Pipiln orcgouns; Pipilo megalony'x; Pipilo maculatus me galony'x.

Status -Common resident of the Upper Sonnran and Transition zones in northern and eastern Arizona. Its westernmost limits miglit be indicated by a line drawn from the Santa Rita and Santi Catalina mountains in the southeast, to the Hualpai Mountains in the northwest. Apparently strictly resident where found, there being no migratory movement into the lowlands in winter. There are no records from the valley of the lower Colorado River. 
$25^{8}$.

Pipilo maculatus curtatus Grinnell.

Nevada Tow Hes.

Status-Rather uncommon winter visitant along the lower Colorado River: specimens taken between Necdles and Ehrenberg, in February and March, 1910 (Mus. Vert. Zool.), and one at Fort Yuma January 23, 1913 (collection of A. B. Howell). The capture of these specimens constitutes the only records I know of regarding the occurrence of any form of Pipilo maculatus in the lower Colorado Valley (see Grinnell, ı91 1, p. 309).

259.

Pipilo fuscus mesoleucus Baird.

C.ANON TOWHEE.

Synonym-Pipilo mesoleucus.

Status-Common resident in the Upper Sonoran zone, and in Lower Sonoran also in parts of southern Arizona. All of the published records are from points south and east of the Mogollon divide; but the species is absent from the exceedingly arid southwestern corner of Arizona, and thus seems to occupy a belt extending across the state from Fort Mohave in the northwest (Fisher, I893b, p. 105), south to the extreme southeastern corner. Cous' ( I866c, p. 262) record of the occurrence of the species on the lower Colorado River lacks confirmation. Zonally it occupies an intermediate region between Pipilo $m$. montanus and $P$. aberti, at places ascending or descending slightly into the habitats of those species. In no one spot, however, are all three to be founci.

260.

\section{Pipilo aberti Baird.}

ABERT TOWHEE.

Status-Common resident of the valley of the Colorarlo River, and its tributaries in western and southern Arizona. Abundant in the Lower Sonoran river valleys of the south (Gila, Santa Cruz, San Pedro, etc.) extending as far north as Fort Grant (Cones, I868, p. 84) and Fort Whipple (Coale, 1894, p. 218). Along the Colorado it has been found to the extreme northwestern corner of the state: confluence of the Beaverdam and Virgin rivers (Fisher, 1893b, p. 105), but no farther to the eastward.

261.

Oreospiza chlorura (Audubon).

GREEN-TAILEN TOWHLE.

Synonyms-Fringilla blandingiana; Zonotrichia blandingiana; Pipilo chlorura; Atlapetes chlorurus.

Status--A common migrant, occurring indifferently on Boreal mountain tops or on the arid, semi-desert plains. Reported in winter from the Coloradc Valley (Cooper, 1870 , p. 248), and as an occasional winter visitant in the Santa Catalina Mountains in extreme southern Arizona (Scott, 1887, p. 204). Specimens in the collection of F. S. Daggett taken at Fort Lowell in October, November, December and Jannary. 
262.

\section{Cardinalis cardinalis superbus Ridgway.}

Arizona Cardinal.

Synonyms-Cardinalis virginianus; Cardinalis igneus; Cardinalis virginianus igncus; Cardinalis superbus.

Status-Fairly abundant in the valleys of extreme sontheastern Arizona, where it is probably resident throughout the year. One specimen in the collection of F. S. Daggett, no. 6475, male, Tucson, January IO, I908. There is record of one from the "Colorado River, Arizona", November 30, I87 I (Ridgway, I885c, p. 344). Aside from this it is reported only from localities in the valleys of the Santa Cruz and San Pedro rivers.

263.

Pyrrhuloxia sinuata sinuata (Bonaparte).

Arizona Pyrrhuloxia.

Synonym-Pyrrhuloxia sinuata beckhami.

Status-Resident in the Lower Sonoran valleys of southern Arizona. Common in the vicinity of Tucson; also reported from Fort Grant, Yuma, Quijotoa, and the San Pedro and Santa Cruz rivers.

264.

Zamelodia ludoviciana (Linnaeus).

ROSE-BREASTED GROSBEAK.

Status-Only one record, that of an adult male taken by R. D. Lusk in the Huachuca Mountains, June 29, I894 (Swarth, I904b, p. 44). The specimen is now in the Swarth collection.

265.

Zamelodia melanocephala melanocephala (Swainson).

BLACK-HEADED GROSBEAK.

Synonyms-Guiraca melanocephala; Goniaphea melanocephala; Hedymeles melanocephalus; Habia melanocephala.

Status-Breeds commonly in the Transition zone of the higher mountains throughout the state; and during the migrations it is of general occurrence elsewhere as well. There is no authenticated instance of its occurrence through the winter months.

266.

Guiraca caerulea lazula (Lesson).

WeStern Blue Grosbeak.

Synonyms-Guiraca caerulea; Goniaphea coerulea; Guiraca caerulea eurhyncha.

Status-Restricted almost entirely to the hot Lower Sonoran river valleys. A common summer visitant along the San Pedro and Santa Cruz rivers, and about Tucson. The various records from the Colorado River are none of them of birds actually found breeding, though there can be little doubt but that they do so: Fort Mohave, May; Yuma, May; confluence of Beaverdam and Virgin rivers, May; Big Sandy River, July. In central Arizona it extends north to Fort Apache and Fort Grant (Henshaw, 1875b, p. 298) and to Fort Whipple (Coues, r866a, p. 88). 
267.

\section{Passerina amoena (Say).}

Lazuli Bunting.

Synonyms-Spiza amoena; Cyanospiza amocna.

Status-Of abundant occurrence as a migrant, and quite generally distributed, though I know of no records of its occurrence in northeastern Arizona. Probably breeds, though definite data is lacking. Coues ( $1866 \mathrm{a}$, p. 89) reports it as an uncommon summer visitant at Fort Whipple, and Scott (1887, p. 205) states that it has been found breeding near Tucson. In neither case is more detailed information given.

268.

\section{Passerina versicolor pulchra Ridgway.}

BeAutiful Bunting.

Synonym--Passerina versicolor.

Status-An adult female taken by F. Stephens at Crittenden, near the Santa Rita Mountains, July 14, 1884 (Brewster, 1885b, p. 198). Not otherwise known to occur in Arizona.

269.

Passerina ciris (Linnaeus).

Painted Bunting.

Synonym-Cyanospiza ciris.

Status-Of occasional occurrence in extreme southeastern Arizona in late summer and curing the fall migration. Henshaw (1875b, p. 30I) reported it as present in considerable numbers at Fort Bowie and Fort Crittenden in August and September, I874. One specimen taken in the Huachuca Mountains, July I2, 1902 (Swarth, 1904b, p. 46). There are three specimens in the Museum of Vertebrate Zoology taken at Fort Huachuca on August 29 and September I2 and I3, 1884 , respectively.

270.

Spiza americana (Gmelin).

- Dickcissel.

Synonym-Euspiza americana.

Status-Only known to occur in Arizona as observed by Henshaw (1875b, p. 295), who found it in small numbers and secured specimens on the San Pedro River, at Fort Crittenden and at Fort Lowell, in August and September, 1873 and 1874 ; and from a specimen taken by Brown at Tucson, September II, 1884 (Scott, 1887, p. 205).

$27 \mathrm{I}$.

Calamospiza melanocorys Stejneger.

Lark Bunting.

Synonym-Calamospiza bicolor.

Status-An abundant migrant and winter visitant on the plains of southern and western Arizona. There are numerous recorded instances of its occurrence at points in the south-Tombstone, San Pedro Valley, Tucson, etc., north to Fort Grant ; and it also occurs in lesser numbers along the Colorado River, but apparently not in the extreme southwestern corner, the vicinity of Yuma. Not reported south of Cibola, on the Colorado River (Mus. Vert. Zool.), nor west of Agua Caliente, on the Gila River (Swarth, MS). Neither do I know of any instance of its occurrence in northern Arizona-north of the Mogollon Divide-though it should occur in that region as a migrant. 
272.

\section{Piranga ludoviciana (Wilson).}

WESTERN TANAGER.

\section{Synonym-Pyranga ludoviciana.}

Status-Summer visitant in the Transition zone and upward, of common occurrence in the north: San Francisco Mountain (Merriam, I890, p. 40) ; Mogollon Mountains (Mearns, I890a, p. 260). In diminishing numbers to the southward, as far as the Santa Catalina Mountains (Scott, I888, p. 29), and Huachuca Mountains (Swarth, I904b, p. 47). These latter points, where it is of rare occurrence in the summer, probably indicate the extreme southern limits of the breeding range of the species. Common and generally distributed during the migrations.

273.

Piranga hepatica Swainson.

HePATIC TANAGER.

Synonyms-Pyranga asarae; Pyranga hepatica, part.

Status-Common summer visitant in the Transition zone throughout the state. Reported in summer from San Francisco Mountain, the Mogollon, Santa Catalina, Santa Rita, Huachuca, Chiricahua, and White mountains, and at Fort Whipple; and as a migrant from various intervening points. A single specimen was taken in the Hualpai Mountains, July 8, 1902 (Stephens, I903, p. IO4), and one was seen at the confluence of the Beaverdam and Virgin rivers, in extreme northwestern Arizona, May 9, I89I (Fisher, I893b, p. I09).

274 .

Piranga rubra cooperi Ridgway.

COOPER TANAger.

Synonyms-Pyranga acstiza; Pyranga conperi; Pyranga aestiva cooperi; Pyranga hepatica, part.

Status-Common summer visitant in the Lower Sonoran zone of southern and western Arizona, principally along the hot river valleys of the Colorado and its tributaries. Breeds along the Colorado as far north as Fort Molnave (Cooper, I870, p. I42), in eastern Arizona north to San Francisco River, in Graham County (Henshaw, I875b, p. 239), and to the vicinity of Tucson.

275 .

Progne subis subis (Linnaeus).

Purple Mar'tin.

Synonyns-Progne purpurea; Progne subis hesperia.

Status-Breeds commonly in some sections, but there is not at hand data to indicate the details of its distribution through the state. It is known to be a summer visitant at Fort Whipple, in the Upper Sonoran zone (Cones, I866a, p. 72), in the Transition of the Mogollon Mountains (Mearns, I890a, p. 260), and in the Lower Sonoran at Tucson (Swarth, I905a, p. 49). Reported from other points as a migrant only.

276.

Petrochelidon lunitrons lunifrons (Say).

Ci.jFF Siwaliow.

Synonyms-Hirundo lunifrons; Pctrochelidon lunifrons tachma.

Status-A common-summer visitant, where suitable conditions prevail, 
throughout the state, except along the southeastern boundary, where it is replaced by $P$. l. melanngastra. The cliff swallow has been found breeding abundantly at various scattered points-Fort Whipple, Little Colorado River, Bill IVilliams River, Fort Verde, and at several places on the Colorado River between Needles and Yuma. Breeding birds from Fort Verde have been referred to $P$. $l$. tachina (Miller, I906, p. I77).

277 .

\section{Petrochelidon lunifrons melanogastra (Swainson).}

Mexican Cliff Sivallow.

Synonym-Petrochelidon melanogaster.

Status-Occurs as a summer visitant along the Mexican boundary of extreme southeastern Arizona, as far west as Nogales (Mearns, I90 I, p. I77). The northern limits of its range have not yet been ascertained.

278.

\section{Hirundo erythrogastra Bodclaert.}

Barn SWAI.LOW.

Synonyms-Hirundo "ufa; Hirundo horreorum; Chelidon crythrogaster.

Status--Of rare and local occurrence. The only breeding records known to nue are as follows: Tacson and the Santa Catalina Mountains, up to 5,000 feet (Scott, 1888, p. 3I) ; Elgin, Santa Cruz County (Breninger, I898a, p. I I7) ; San Pedro River (Swarth, 1904b, p. 48). There are singularly few records of its occurrence as a migrant.

279 .

Iridoprocne bicolor ( $\mathrm{Vieillot).}$

TREL: SWALLOW.

Synonyms-Firundo bicolor; Tachycincta bicolor.

Status-I know of no instance of this species having been founci breeding at any point in Arizona, and it has been observed but seldom as a migrant. Reported from Cienega Station in April (Brewster, I882, p. 146), from Tucson in March (Scott, I888, p. 31), and from the Dragoon Mountains in May (Osgood, 1903 , p. 150).

280 .

\section{Tachycineta thalassina lepida Mearns.}

Northern VIOLET-GREen Sivallow.

Synonyms-Hirundo thalassina: Herse thalassina: Tachycineta thalassina.

Status-A common summer visitant of high Transition throughout Arizona. Reported from numerous localities-mountains near Fort Whipple, Santa Catalina Mountains, Mogollon Mountains, Huachuca Mountains, etc. Of general distribution during the migrations.

$28 \mathrm{I}$.

Riparia riparia (Linnaeus).

BANK SWALLOW.

Synonyms-Cotyle riparia: Clizicola riparia.

Status-Apparently of rare occurrence. Has been seen in summer at Fort Whipple (Cones, I866a, p. 72), and in the vicinity of Tucson (Scott, I888, p. 31) and the Santa Cruz River (Swarth, I905a, p. 49). 
282.

Stelgidopteryx serripennis (Audubon).

Rough-winged Swallow.

Synonym-Cotyle serripennis.

Status-Though there are numerous instances of the occurrence of this species as a migrant in various parts of the state, breeding records are too few to permit a definite statement as to the region occupied during the nesting season. Reported as breeding at Fort Whipple. (Coues, I866a, p. 72), Cienega Station, southeastern Arizona (Brewster, I882, p. I46), along the Santa Cruz and San Pedro rivers (F, C. Willard, MS), and Tucson, and at points on the Colorado River between Ehrenberg and Yuma (Mus. Vert. Zool). Also observed at Fort 'Mohave, Gila Bend, confluence of Beaverdam and Virgin rivers, Fort Verde, Mellen, Pima Indian Reservation, Keam Cañon, and the Sulphur Spring Valley. Seen in February on the Colorado River (Kennerly, I859, p. 24), and at Fort Mohave (Cooper, I870, p. I10), so it may be found to occasionally pass the winter this far north.

283.

Bombycilla garrula (Linnaeus).

BOHEMIAN WAXWING.

Synonym-Ampelis garrulus.

Status-A rare midwinter straggler from the north. Cooper (I86r, p. I22) secured a single specimen at Fort Mohave, Jannary IO, I86I, the only occasion on which the species has been observed in Arizona. This bird, an adult female, is now number 4207 , Museum of Vertebrate Zoology.

284 .

Bombycilla cedrorum Vieillot.

Cendar Waxwing.

Synonym-Ampelis cedrorum.

Status-Of rare and irregular occurrence. Henshaw (1875b, p. 299) secured a specimen thirty miles south of Fort Apache, September II, I873, under circumstances indicating that it may have been breeding. Otherwise noted during the migrations and in winter, at a few scattered localities: Galeyville, Cochise County, January; Tucson, March, May and June; Grand Cañon, September; Huachuca Mcuntains, April, May, October.

285 .

Phainopepla nitens (Swainson).

Pirainoperta.

Synonyms-Ptiliogonys nitens; Cichlopsis nitens.

Status-Common summer visitant in the Lower Sonoran of southern and western Arizona. Reported from many points, nortin as far as Fort Apache (in August, not necessarily a breeding record), Fort Whipple, and Fort Mohave. Remains through the winter locally in southern Arizona, and along the Colorado River. In the late summer there is a dispersal of individuals into higher altitucles, and possibly to more northern localities, than are occupied during the nesting time. Found breeding at Fort Mohave in February (Fisher, I893b, p. I I3). 
286.

\section{Lanius borealis Vieillot.}

\section{NORTHERN SHRIKE.}

Synonyms--Collyrio borealis; Collurin boreulis.

Status-Only one record, that of a specimen secured by Coues (I866a, p. 73) at Fort Whipple, in Febrnary, 1865.

287.

\section{Lanius ludovicianus excubitorides Swainson.}

\section{WHITE-RUMPED SHRIKE.}

Synonyms-Lanius ludovicianus; Collyrio excubitorides; Collurio ludovicianus var. excubitorides; Collurio excubitoroides.

Status-Fonnd in the Lower Sonoran zone of sonthern Arizona, along the Colorado River, and the Desert of the Little Colorado in northeastern Arizona. Apparently restricted to the Lower Sonoran zone in the breeding season but ranging into Upper Sonoran in late summer and fall: one specimen, Fort Whipple, September 4, 1864 (Coues, 1866a, p. 73) ; foothills of the Huachuca Mountains, October (Swarth, 1908, p. 115). Not known to occur in the high plateau region of central Arizona, and but sparsely distributed in the region where it is found.

288.

Vireosylva olivacea (Linnaeus).

RED-EYED VIREO.

Synonym-Vireo olivaceus.

Statıs-But a single record, that of a specimen secured by Lusk in the Huachuca Mountains, May 20, I895. This specimen is now in the Swarth collection (Swarth, Igo4b, p. 49).

289 .

\section{Vireosylva gilva swainsoni (Baird).}

WesterRn WARBLing Viré.

Synonyms-Vireo gilvus; Vireo swainsoni; l'ireo giluus swainsoni.

Status-A common summer visitant of the Upper Sonoran and Transition zones of northern and central Arizona: Fort Whipple (Coises, I866a, p. 73) ; San Francisco Mountain (Merriam, 1890, p. 98). Of rare occurrence south of the central plateau region, but has (xcasionally been found breeding at the extreme southern boundary of the state: Santa Catalina Mountains (Scott, I888, p. 32); Huachuca Mountains (Willard, I908c, p. 230). Abundant and of general distribution during the migrations.

290.

\section{Lanivireo solitarius cassini (Xantus).}

CASSIN Viréo.

Synonyms-Vireo solitarius; Vireosylvia solitaria; Vireo solitarius cassini.

Status-A migrant, of common occurrence and general distribution. Reported from numerous localities in various parts of the state, but not from the desert region of the northeast corner. Specimens have been taken at Forts Whipple, Mohave, Apache, and Crittenden, and also at San Francisco Mountain, Mount Graham, and the Santa Rita, Santa Catalina, and Huachuca mountains. 
291. Lanivireo solitarius plumbeus (Cones).

Plumbeous Viré. beus.

Synonyms-Vireo plumbeus; Vireosyliva plumbea; Vireo solitarius plum-

Status-Common summer visitant of the Transition zone. Reported from San Francisco Mountain, the Mogollon, Santa Catalina, Santa Rita, Huachuca, and Hualpai mountains, Forts Whipple and Apache, and is undoubtedly to be found in all the higher mountain ranges of the state.

292.

Vireo huttoni stephensi Brewster.

STEPHENS VIREO.

Synonym-Vireo huttoni.

Status-Found in the mountain ranges of southeastern Arizona, in the live oak belt and along the cañon streams, ranging upward to the lower edge of Transition. Probably resident, but nowhere very abundant. Reported from the Chiricahua, Santa Catalina, Santa Rita, and Huachuca mountains, and also, the westernmost record, from the Quijotoa Range (Scott, I888, p. 32).

293 .

\section{Vireo belli arizonae Ridgway.}

ARIZONA VIREO.

Synonyms-Vireo bellii; Vireo pusillus; Vireo belli pusillus.

Status-Common summer visitant in southern and western Arizona. Found along the Colorado River at least as far north as Fort Mohave (Cooper, 186r, p. 122) and the Big Sandy (Stephens, 1903, p. I04). In eastern Arizona it breeds abindantly in the valleys of the Santa Cruz and San Pedro, as in all probability it does along the Gila River also. The northernmost points to which it has been traced in central Arizona are the Gila River, Graham County, in September (Henshaw, 1875b, p. 225), and a point fifty miles south of Fort Whipple, breeding (Couses, 1866a, p. 76).

294.

Vireo vicinior Cones.

GRAY VIREO.

Status-A summer visitant, reported thus far from a few scattered localities in the northern and eastern parts of the state. Coues (1866a, p. 75) secured a single specimen, the type of the species, at Fort Whipple, Henshaw (1875b, p. 227) took migrating birds at Camp Bowie in August, and at Camp Lowell in September, and Stephens ( 1878, p. 93) fonmd it on the Gila River, presumably about at the Arizona-New Mexico boundary, and also near Tucson in April (Brewster. I882, p. I42). Apparently the only positive published breeding record for Arizona is that of Scott (I885a, p. 32I), who reported the species as a common suminer visitant on the eastern slope of the Santa Catalina Mountains, ranging from 2800 to 4000 feet. Merriam ( 1890, p. .40) found it at the Grand Cañon of the Colorado in September, and Fisher (1903: p. 35) at Keam Cañon in July and August, and it may be presumed to breed at both places. 
295.

Protonotaria citrea (Boddaert).

PROTHONOTARY WARLLER.

Status-Only one record, that of a specimen taken by E. W. Nelson at Tucson, May I, 1884 (Cooke, 1904, p. 23).

296.

Vermivora luciae (Cooper).

LUCY WARHLISR.

Synonyms-Helminthophaga luciac; Helminthophila luciae.

Status-An exceedingly abunclant summer visitant in the low river valleys of southern and western Arizona. Common in the valleys of the Santa Cruz and San Pedro, along the Gila (probabiy not above its junction with the San Pedro), and along the Colorado. Ranges north along the Colorado to Fort Mohave at least, in central Arizona to Fort Whipple. Its northern boundary is probably determined by the rise of the country toward the Central Plateau Region. Restricted almost entirely to the Lower Sonoran zone, but in a few places it ranges into Upper Sonoran: west slope of the Santa Rita Mountains (Swarth, rgo5a, p. 8I) ; west slope of the Huachuca Mountains (Willard, I908b, p. 206). Not reported from east of the San Pedro River.

297.

Vermivora virginiae (Baird).

VIRGINIA WARBLER.

Synonyms-Helminthophaga virginiae; Helminthophila virginiac.

Status-An abundant migrant, and a fairly common summer visitant in the Transition zone of some, probably all, of the higher mountain ranges. It has been found in the summer months in the White, Santa Catalina, Huachuca, and San Francisco mountains. Rare in the Hualpai Mountains, where Stephens (1903, p. I04) saw several in June. Of occasional occurrence in the low valleys luring the migrations.

298.

Vermivora rubricapilla gutturalis (Ridgway).

Calaveras Warbler.

Synonyms-Helminthophaga ruficapilla; Helminthopliila ruficapilla; Helminthopila ruficapilla gutturalis; Helminthophila rubricapilla gutturalis.

Status-Abundant and generally distributed during the migrations. Reported from the valley of the Colorado River (Mus. Vert. Zool.), from San Francisco Mountain in the north, and from the Huachuca, Santa Rita and Santa Catalina mountains, and the valley of the San Pedro River, in southern Arizona.

299.

\section{Vermivora celata celata (Say).}

ORANGE-CROWNED WARBLER.

Synonyms-Helminthoplila celata; Vermizora celata orestera.

Status-But few records from Arizona. Reported from Mount Graham (breeding), San Francisco Mountains, San Pedro River, Adonde, Tucson, Fort Huachuca, and Bisbee ( $V$. c. orcstcra Oberholser, I905, p. 243); from the Huachuca Mountains and San Pedro River in April and September (Swarth, Ig04b, p. 52); and from the Colorado Valley (Needles, Cibola, Picacho, and Pilot Knob) from February to May (Mus. Vert. Zool.). 


\section{Vermivora celata lutescens (Ridgway).}

\section{LUTTSCENT WARBLER.}

\section{Synonyms-Helminthophaga cclata; Hclminthophila celata lutescens.}

Status--An abundant migrant, occuring in all parts of Arizona. Has been found at every point where collecting has been carried on in the spring and fall.

301.

\section{Peucedramus olivaceus (Giraud).}

\section{OLIVE WARBLER.}

Synonym-Dendroica olizacea.

Status--Breeds in the Transition zone of the mountains of southern and centra! Arizona. Has been found in the Huachuca, Chiricahua, Santa Catalina. Mogollon and White mountains, and on Mount Graham, and there are other higin rainges at intermerliate points where it will also probably be found. It does not appear to be very abunclant in any part of its range in Arizona. A ferv individnals probably remain through the winter, as it has been reported fron the Santa Catalina Mountains, at I0,000 feet altitude, November 26-29 (Scott, I885b, p. I72), and from the Huachuca Mountains at gooo feet, February 2 I (Swarth, Igo4b, p. 53).

\section{Dendroica aestiva sonorana Brewster.}

SONORA YliLlow WARBLER.

Synonyms-Dendroica aestiza, part; Dendroica acstica morcomi, part.

Status-A common summer visitant in southern and western Arizona, apparently confined almost entirely to the Lower Sonoran river valleys, the Colorado and the Gila, with their tributaries. Has been reported from various points along these streams: Fort Mohave, Yuma, Gila Bencl, Tucson, Tombstone, etc.; and occasionally from localities in Upper Sonoran: Santa Cataiina Mountains, resident up to 4500 feet (Scott, I888, p. 34) The northermmost record I have seen from central Arizona is from Fort Verde (Coale, I894, p. 2I8). I know of no breeding record of a yellow warbler from any point in Arizona north of the Mogollon Divide; what form it is that migrates through this region $I$ do not know (Dindroica acstiz'a Merriam, I890, p. 98, San Francisco Mutntain, etc., August and September; Fisher, I893b, p. I I3, confluence of Beaverdam and Virgin rivers, May; etc.).

$3 \circ 3$.

Dendroica aestiva brewsteri Grinnell.

\section{CALIFORNiA YiLlow WARBien.}

Synonyms-Dendroira aestiza, part; Dendroica acstiz'a mercomi, part.

Status-A common migrant in southern Arizona. I have seen specimens from the Huachuca Mountains, in the extreme southeastern portion of the state (Swarth, Igo4b, p. 53), and from points on the Colorado River (Mus. Vert. Zool.). These are distinctly $D$. a. brezesteri, as distinguished from $D$. a. asstiza of the eastern United States. 
304.

Dendroica coronata (Linnaeus).

MYRTLE WARBLER.

Status-Four records: One from the Chiricahua Mountains, March 26, I88 I (Brewster, I882, p. I37) ; one from T'ucson, January 28, I886 (Scott, I888, p. 34) ; Pima Indian Reservation, Septemher, "one seen" (Breninger, Inorá, p. 46): 'Tucson, one seen January 28, I9I2 (Sloanaker, I9I3, p. 197).

305 .

Dendroica auduboni auduboni ('Townsend).

AUDUBON WARBLER.

Synonym-Sylvicola audubonii.

Status-Common summer visitant in high Transition and upward in the mountains of northern Arizona: San Francisco Mountain, Mogollon Mountains. etc. Abundant in winter in the Lower Sonoran valleys of the southern and western parts of the state: T'ucson, San Perlro River, Yuma, etc. Winter visitant in the Colorado Valley at least as far north as Fort Mohave. Occasional in winter at Fort Whipple (Cones, r86(a, p. 69). Very abundant and of general distribution during the migrations.

306.

Dendroica auduboni nigrifrons Brewster.

BLACK-FRONTED WARRLER.

Synonyms-Dendroica audıboni, part: Dendroica nigrifrons.

Status-Reported from the Huachuca and the Chiricahua mountains, where it is a fairly common summer visitant in the Transition zone. $D$. a. auduboni has been recorded as an uncommon summer visitant in the Santa Catalina Mountains (Scott, I888. p. 34), but I have seen typical examples of nigrifrons (in the collection of F. S. Daggett) taken in these mountains in June, I906, so that the breeding range of this form extends at least that far north. Probably it includes all the high mountains south of the Mogollon Plateau, but it is impossible at present to inrlicate exactly the dividing line between the breeding ranges of nigrifrons and auduboni. From the critical comments made upon Dendroica auduboni by Coues in his "List of Birds of Fort Whipple" ( $866 \mathrm{a}$, p. 69) it is evident that he collected in that region specimens approximating the characters of D. a. nigrifrons.

307.

Dendroica graciae Baird.

Grace, Warbler.

Status-A summer visitant in the Transition zone of eastern and central Arizona, apparently least abundant in the extreme southern part of the state. In the Huachuca Mountains it is common during the migrations, but decidedly rare 1n the breeding season. Reported from the Huachuca, Chiricaluta, Santa Catalina, Mogollon, and White mountains, San Francisco Mountain and Fort Whipple. There is no record of its occurrence in the lowlands during the migrations. 308.

Dendroica nigrescens (Townsend).

Bi.ACK-THROATED GRAY WARBCER.

Status-A common summer visitant in low Transition throughout Arizona. Has been found breeding in the Huachuca, Santa Rita. Whetstone, and Santa Catalina mountains, San Francisco Mountain, and at Fort Whipple. Abundant and generally distributed during the migrations. 
300 .

Dendroica virens (Gmelin).

\section{BLACK-THROATTE GRIEN WARBI.ER.}

Status-Only one record for Arizona, that of an adult male secured at Ransay Cáñon, Huachuca Mountains, May 9, I895 (Fisher, I904, p. 81).

Dendroica townsendi ('Townsend).

TOWNSEND WARBI.ER.

Status-An abundant migrant at all altitudes, both spring and fall, reported from many scattered localities throughout the state (San Francisco Mountain, Huachuca Mountains, Tucson, Yuma, etc.). Scott ( 1888, p. 35) took one specimen at Mineral Creek, Pinal County, November 2, I882, but there are no midwinter records.

Dendroica occidentalis ('Townsend).

\section{Hermit' Warbler.}

Status-An abundant migrant, occurring in all parts of Arizona in the spring and fall. Reported from Fort Whipple, San Francisco Mountain, Huachuca Mountains, Yuma, etc.

Seiurus noveboracensis notabilis Ridgway.

Alaska Water-Thrush.

Synonyms-Sciurus tenuirostris; Seiurus noveboracensis; Siurus naevius.

Status-A rare migrant. The published records are as follows: Rio Colorado, October (Ganıbel, I843, p. 26ı ) ; one specimen, Camp Crittenden, August (Henshaw, 1875b, p. 204); one specimen, adult male, Tucson, May 4 (Brewster, 1882, p. I38) : two specimens. Santa Catalina Mountains, 3500 fcet, an adult female on September 2, and an adult male on September 3: 1884 (Scott, r888, p. 35) ; one specimen, Huachuca . Mountains, 5500 feet. August 31, r903 (Swarth, 1904b, p. 56).

3 I3.

\section{Oporornis tolmiei ('Townsend).}

Macgillturay Warbleir.

Synonyms-Geothlypis macgillivrayi; Gcothlypis philadclphia var. macgilliirayi; Geothlypis tolmici.

Status-A summer visitant in the higher mountains of central Arizona. Fort Whipple, April to September (Coues, I866a, p. 70) ; east central Arizona, "common summer resident" (Henshaw, I875a, p. I56). Abundant and generally distributed during the migrations.

314.

\section{Geothlypis trichas occidentalis Brewster.}

WESTERN YEI.L.OWTIIROAT.

Synonym--Geothlypis trichas, part.

Status-A common migrant, and, on the lower Colorado River, a winter visitant. May breed in northern Arizona, a summer itcord from Fort Whipple (Coues, 1866a, p. 69), possibly pertaining to this subspecies. Colorado River below Yuma, December (Price, I899. p. 93). Huachuca Mountains, migrant (Swarth, I904h, p. 56). 
$3^{15}$ Geothlypis trichas scirpicola Grinnell.

TUle: YÉLLUN'THROAT.

Synonyms-Geothlypis trichas, part; Geothlypis trichas occidentalis, part.

Status-Breeds in the valleys of extreme southern Arizona_and along the lower Colorado River, but from the generally unfavorable nature of the region outside of the latter district, it occurs in but small numbers, and at widely scattered intervals. Found in summer in the vicinity of Tucson (Scott, 1888, p. 35), on the San Pedro River (Swarth, 1904b, p. 56), and on the lower Colorado River (Mus. Vert. Zool.). For the use of the name scirpicola for the breeding yellowthroat of southern Arizona, see Swarth, I912, p. 7 I.

316.

\section{Icteria virens longicauda Lawrence.}

LONG-TAILED CHAT.

Synonyms-Icteria viridis; Icteria longicauda.

Status-Abundant summer visitant in the Lower Sonoran river valleys, and through the Upper Sonoran zone in the lower cañons of the mountain ranges. Found in summer at Fort Mohave, Fort Whipple, Fort Grant, Tucson, Fort Apache, Huachuca Mountains, etc.

$3 \mathbf{I} 7$

Wilsonia pusilla pileolata (Pallas).

Pileol.ated WARBlek.

Synonyms-Myiodioctes pusillus; Myiodioctes pusillus pilcolatus, part; My'iodioctes pilcolatus; Sylicinia pusilla pilcolata; Sylvania pusilla, part.

Status-The only breeding record for Arizona is that of Coues (I866a, p. 7I) who reported the species as a common summer visitant about Fort Whipple, where he found it from May to September. It is an exceedingly common migrart in al! parts of the state, and one that is found at all altitudes.

3 I8.

Wilsonia pusilla chryseola Ridgway.

Golden Pileglatéd Warble,

Synonyms-Myiodioctes pusillus pileolatus, part; Sylvania pusilla, part.

Status-Occurs "during migration southward and eastward to . . . Arizona (Pinal County, September. October; Lowell, April; Fort Verde, May: San Francisco Mountains, August 3I ; Cienega; Tucson)" (Ridgway, I902, p. 7I4). Observed as a common migrant in the Colorado Valley, between Chemehuevis Valley and Potholes in the spring of rgro (Mus. Vert. Zool.).

319.

Setophaga ruticilla (Linnaeus).

AMERICAN REDSTART.

Status-Its cccurrence in Arizona is based upon the record by Scott (I 888 , p. 36), of two specimens, an adult male taken by himself in the Santa Catalina Mountains, 4500 feet elevation. August 12, I 884 , and another taken by Herbert Brown at Tucson 
320.

Setophaga picta Swainson.

PAINTED REDSTART.

Statıs-A common summer visitant in the higin mountains of southern and central Arizona, in low 'Transition and high Upper Sonoran. Found as far north as the Mogollon Monntains and the Tonto Basin (Mearns, I8yoa, p. 26I). Reported from Camp Apache, Mount Graham, and the Chiricahıa, Santa Rita, IJuachuca. Santa Catalina, and Whetstone mountains.

$32 \mathrm{I}$

Cardellina rubrifrons (Giraud).

RED-FACED WARBLER.

Status-Common summer visitant in the Transition zone of the mountains of southeastern Arizona. The northernmost point to which it has been traced is the Mogollon Mountains (Mearns, I800a, p. 26I), and it has also been found in summer at Fort Apache, Mount Graham, the Santa Catalina, Santa Rita, and Huachuca mountains. There are other high ranges from which there are no reports, where it undoubtedly occurs.

322.

Anthus rubescens ('Tunstall).

American PipiT.

Synonyms-Anthus hidovicianus; Anthus pensilianicus.

Status-A common winter visitant in the lowlands of southern and western Arizona, reported from various scattered localities-Fort Whipple, Yuma, Tucson, etc. No winter records from points north of the Mogollon Divicie. Possibly breeds on San Francisco Mountain, where it was found at timber line in the late summer (Merriam, I890, p. 99).

\section{Cinclus mexicanus unicolor Bonaparte.}

AMERICAN DIPPER.

Synonyms-Hydrobata mcricana; Cinclus mexicanus.

Status-There are but three definite published statements in regard to the occurrence of the dipper in Arizona. Although Cones (1866a, p. 66) included the species in his list of birds of Fort Whipple, he did not himself meet with it. Henshaw (I875b, p. I59) found it fairly common in summer on some of the streams of the White Mountains; Brewster (1882, p. 76) records a specimen secured in the Chiricahua Mountains, March 20; and one was seen in the Huachuca Mountains, August 4, I902 (Swarth, I904b, p. 59).

Oreoscoptes montanus ('Townsendi).

Sage Thrasher.

Synonym-Mimus montanus.

Status--An abundant winter visitant of the plains and valieys of southern Arizona, reported from many localities between Yuma and the eastern boundary; also along the lower Colorado River. I know of no winter records from points north of the Mogollon Divide. There are no published instances of its breeding in Arizona, though it may be found doing so in the northeastern portion-fron the Little Colorado River northward-where Merriam (I890, p. Ioo) observed it in small numbers in the late summer of 1889. 
325.

\section{Mimus polyglottos leucopterus (Vigors).}

WESTERN MockingriRd.

Synonyms-Mimus polyglottus; Mimus polyglottus var. caudatus.

Status-A common summer visitant in the Lower Sonoran valleys, and in places extending up into Upper Sonoran. It is permanently resident in the hot valleys of southern Arizona, but there is a vertical migration downward from the foothill regions where it occurs in summer; and possibly an entire departure from northern Arizona during the winter months. Cones (1866a, p. 65) speaks of it as a summer resident only in the vicinity of Fort Whipple, and Osgood (1903, p. I50) mentions its arrival in the Sulphur Spring Valley, Cochise County, on April 15. In the foothills of the Huachuca Mountains it occurs in summer only, while it is reported in February from a point on the San Pedro River, fifteen miles distant and about five hundred feet lower (Willard, I9IOc, p. IIo). The few records from northern Arizona (Little Colorado River, Keam Cañon, and Hualpai Mountains), are all for the summer months.

Probably a winter visitant only on the Colorado River below Needles (Mus. Vert. Zool.).

326.

Toxostoma rufum (Linnaeus).

Brown Thrasher.

Status-But one record for Arizona, that of a male bird taken in the foothills of the Huachuca Mountains (4500 feet altitude), on October 5, 1907 (Swarth, 1908, p. I15).

327.

\section{Toxostoma curvirostre palmeri (Cones).}

\section{PALMHR THRASHER.}

Synonyms-To.rostoma zetula; Harporhynchus curivostris; Harporhynchus curitirostris palr?eri.

Status-A common resident in the Lower Sonoran valleys of southeastern Arizona. Its range has been traced east to the valley of the San Pedro (Brewster, $188_{2}, p .7 \mathrm{r}$ ), north to the Hassayampa (1. c.) and the Big Sandy (Stephens, 1903, p. 105), to Fort Grant (Cones, 1868, p. 83) and the Salt River. Valley.

328.

\section{Toxostoma bendirei (Couses).}

\section{BENDIRE THRASHER.}

Synonyms-Harporhynchus bendirei: Harporhynchus cincreus var. bendirei.

Status-Locally a common resident in the Lower Sonoran valleys of southeastern and northeastern Arizona, but our present knowledge seems to indicate an exceedingly irregular and disconnected range. In southeastern Arizona it is very abundant in the valley of the Santa Cruz, west of the Santa Rita Mountains, whilz it is almost unknown east of that range. It is common in the plains and valleys stretching northwest of Tucson, as far as Phoenix and along the Gila River at least as far as Gila Bend (Pember, I892, p. 6). In northern Arizona it has beell reported from Keam Cañon in July and August (Fisher, 1903, p. 35), and from Beale Spring in July (Stephens, Ig03, p. 105). 


\section{LECONTE THRASHER.}

Synonyms-Harporhynchus lecontei; Harporhynchus redicivius lecontei.

Status-A resident of the arid Lower Sonoran plains of southern and western Arizona. In the valley of the Colorado River north to the extreme northwestern corner of the state (Merriam, I895, p. 59) ; east in the valley of the Gila about to Phoenix, Maricopa, Casa Grande, and Picacho Peak (Mearns, I886b, p. 299) ; its northwestern limits at the base of the Plateau escarpment (Merrian, l. c.). In southern Arizona it has not been observed at any point east of the valley of the Santa Cruz River.

330 .

\section{Toxostoma crissale Henry.}

\section{Crissal Thrasheir.}

Synonym-Harporhynchus crissalis.

Status-Common resident, principally in Lower Sonoran; locally abundant but rather irregt:larly distributed. Ranges north in the valley of the Colorado River as far as the mouth of Diamond Creek, Molave County (Mearns, I886b, p. 292) ; in central Arizona to Fort Verde (Mearns, 1. c.). In the valley of the Gila it has been traced east to the mouth of San Carlos Creek (Mearns, 1. c.). In southeastern Arizona it is common at Fort Bowie, and in the valleys of the San Pedro and Santa Cruz rivers ; in the northwest reported as breeding in the Hualpai Mountains (Stephens, I903, p. I05). There are no records from northeastern Arizona, and in all probability its range in this direction is limited by the great Mogollon Divide.

331.

Heleodytes brunneicapillus couesi (Sharpe).

\section{CACTUS WREN.}

Synonyms-Campylorhynchus brunneicapillus; Heleodytes brunneicapillus; Heleodytes brunneicapillus anthonyi.

Status-A common resident of the Lower Sonoran zone in southern and western Arizona. Most abundant in the hot valleys of the southern part of the state. In western Arizona ranges as far north as Beale Spring (Stephens, 1903, p. I05); in eastern Arizona there are no records from north of the Gila River.

\section{ROCK WREN.}

Synonyms-Troglodytes obsoletus; Thryothorus obsoletus.

Status-Has been found in every part of Arizona where observations have been made. In the southern valleys a permanent resident, but in the north probably found in summer only (see Cones, I866a, p. 77), as also in the higher mountains.

\section{CAÑON WREN.}

Synonyms-Thryothorus mexicanus; Catherpes mexicanus; Catherpes mexicanus punctulatus; Catherpes mexicanus polioptilus. 
Status-Common resident in suitable localities throughout the state, ranging through Lower and Upper Sonoran into lower Transition. Most abundant in the Upper Sonoran zone of the various mountain ranges, but found also on low, rocky hills in the hot southern valleys, along the Colorado River, and on the deserts of northeastern Arizona.

Thryomanes bewicki eremophilus Oberholser.

\section{DESERT WREN.}

Synonyms-Thryothorus becickii; Thryothorus bewicki leucogaster; Thryomanes becuicki leucogaster: Thryothorus bervickii murinus; Thryothorus bewickii bairdi; Thryomancs beccickii bairdi; Thryomanes bewickii drymoccus.

Status-Common resident in the Upper and Lower Sonoran zones of southern, and parts of western, Arizona. Has been reported in summer from the Chiricahua. Huachuca, Santa Rita and Santa Catalina mountains, Santa Cruz River near Tucson, Fort Whipple, the Big Sandy River, and many interınediate points, all south and west of the Mogollon Divide. I have seen no records from Arizona localities north of that range. A winter visitant only in the lower Colorado Valley (Mus. Vert. Zool.).

335 .

Troglodytes aëdon parkmani Audubon.

PARKMAN WREN.

Synonyms-Troglodytes parkmanni; Troglodytes domesticus parkmani: Troglodytes aedon; Troglodytes acdon marianae; Troglodytes aedon astecus.

Status-A summer visitant in the Transition zone of the higher ranges. Remains through the winter in the valley of the Colorado River, and probably in thers of the hot valleys of southern Arizona; generally distributed during the migrations. Has been found in summer in the Santa Catalina, Santa Rita, Huachuca, Mogollon, Hulalpai, and San Francisce mountains, and at Fort Whipple.

336 .

\section{Nannus hiemalis pacificus (Baird).}

WESTERN WINTER WREN.

Synonym-Olbiorchilus hiemalis pacificus.

Status-But one published record for Arizona, that of a specimen taken in the Huachuca Mountains, April 2, I902 (Swarth, I904b, p. 60). There is a specimen in the Field Museum of Natural History, Chicago (no. 8I 40) labelled "Grand Cañon, March, 1887."

3.37 .

Telmatodytes palustris plesins (Oberholser).

Western Marsh Wren.

Synonyms-Cistothorus palustris; Tclmatodytes palustris; Cistothorus palustris var. paludicola: Cistothorus palustris plesins.

Statıs-Possibly a summer visitant at suitable points, but the only definite record I have seen of a marsh wren as such is from Fort Whipple, where Coues (1866a, p. 78) found it a common summer resident. There are singularly few published references to the species, even as a migrant in Arizona: Tucson, a rare migrant (Scott, I888, p. I65); Moencopie, September (Merriam, I890, p. 100); Sulphur Spring, Cochise County, March (Osgood, 1903, p. I5I) ; Colorado River, March, igro (Mus. Vert. Zool.). 
338.

Certhia familiaris albescens Berlepsch.

\section{Mexican Creiper.}

\section{Synonym-Certhia familiaris mexicana.}

Status-A common summer visitant in high Transition in the mountain ranges of extreme southeastern Arizona. Reported from the Chiricahua Mountains (Brewster, I882, p. 8I), the Santa Rita Mountains (Brewster, I885b, p. 197), the Santa Catalina Mountains (Scott, 1885c, p. 350), and the Huachuca Mountains (Swarth, I904b, p. 60).

339.

Certhia familiaris montana Ridgway.

Rocky Mountain Creeper.

Synonyms-Certhia faniliaris; Certhia ancricana; Certhia familiaris var. americana.

Status-Summer visitant in the higher mountains of northern and central Arizona. Has been found breeding on San Francisco Mountain, Mount Graham, and the Mogollon Mountains. One record of its occurrence as a migrant in southern Arizona (Swarth, 1904b, p. 6I ; Huachuca Mountains, March, two specimens), and one from northern Arizona in winter (Kennerly, 1859, p. 29; Pueblo Creek, January).

340.

\section{Sitta carolinensis nelsoni Mearns.}

\section{Rocky Mountain Nuthatch.}

Synonyms--Sitta carolinensis; Sitta aculeata; Sitta carolinensis aculeata.

Status--Common summer visitant in the Transition zone, sonetimes in high Upper Sonoran. In some of the more southern ranges, the Santa Catalina and Huachuca mountains, it is known to remain throughout the year. In central Arizona it is recorded as a permanent resident at Fort Whipple (Coues, I866a, p. 78), and as occurring in the Mogollon Mountains in summer, and in the Verde Valley in winter (Mearns, I890a, p. 262). Found at Williams in February (Wetmore, 1908, p. 386). The only record from the arid Lower Sonoran southwestern portion of Arizona is from Sacaton (Gilman, I9IIa, p. 35), where it was seen from September 3 until the first week in December, I9IO.

$34 \mathrm{I}$.

Sitta canadensis Linnaeus.

RED-BREASTED NUTHATCH.

Status-There are very few Arizona records. One taken at Fort Yuma (Baird, I861, p. 6). The next record is of a specimen in the Santa Catalina Mountains, October 29, I885 (Scott, I888, p. I65). Found breeding in the highest parts of the San Francisco and Mogollon mountains (Mearns, I8goa, p. 263) ; four specimens in the Huachuca Mountains, April 6, Ig02 (Swarth, I904b, p. 6r), and several seen at Sacaton during October, IgIo (Gilman, I9I Ia. p. 35 ). 
342.

\section{Sitta pygmaea pygmaea Vigors.}

Pigmy Nuthatch.

Synonym-Sitta pusilla var. py'gmaca.

Status-Common resident in the Transition zone throughout the state. Is apparently non-migratory, and though found on all of the higher mountains, has never been observed, even in winter, in the intervening low valleys.

343.

Baeolophus inornatus griseus (Ridgway).

Gray TrTmouse.

Synonyms-Lophophanes inornatus; Parus inornatus ridgwayi; Parus inornatus griseus.

Status-Several records from the lower slopes of San Francisco Mountain and neighboring localities, where it is probably resident. Also reported from the Grand Cañon in September (Merriam, I890, p. 4I ), from Keam Cañon in July, and from Fort Defiance (Baird, I86r, p. 6). Coues (1866a, p. 79) found it as a winter visitant at Fort Whipple. Apparently of rare occurrence in southern Arizona, judging from the absence of records. 'The only definite statement of its occurrence in the south is that of Brewster (1882, P. 79), who states that it is of rare occurrence in the Chiricahua Mountains. Henshaw ( $1875 \mathrm{~b}$, p. I67) speaks of it as occurring in the oak region of southern Arizona, but mentions no particular locality, and lists no specimens.

344 .

Baeolophus wollweberi (Bonaparte).

Bridled Titmouse:

Synonyms-Lophophanes wollacebri; Parus avollweberi; Baeolophus wollacberi annexus.

Status-Common resident of the Upper Sonoran foothill country of the mountains of southeastern and central Arizona. Reported from nearly ali the ranges south and west of the Mogollon Divide, and as far north as Fort Whipple (Cones, r865a, p. 79). Occasionaliy wanciers to a lower zone in the fall and winter, as evidenced by its occurrence at Sacaton in October and November, Igog (Gilman, rgro, p. 46). Prceminently a bird of the oak woods.

345 .

\section{Penthestes sclateri (Kleinschmidt).}

MEXICAN CHICKADEE.

Synonyn-Parus meridionalis.

Status-In Arizona it is known to occur only in the Transition zone of the Chiricahua Mountains ( 7000 to 10,000 feet), where it is reported to be not uncommon (Brewster, I882, p. 79).

346.

\section{Penthestes gambeli gambeli (Ridgway).}

Mountain ChickadeE.

Synonyms-Parus montanus; Poccile montanus; Parus gambeli.

Status-Common resident in the higher mountains of northern and central Arizona: San Francisco Mountain, Mogollon Mountains, Fort Whipple, etc., south to Mount Graham. Occurs in the Santa Catalina Mountains in winter 
(specimens in the collection of F. S. Daggett) and may breed in that range, as it has been seen there in June and July (Rhoads, I892, p. 125). Mr. F. S. Daggett also has specimens in his collection taken in the Santa Catalina Mountains in June.

347.

Psaltriparus plumbeus (Baird).

LEAD-COLORED BUSH-TIT.

Synonyms-Psaltria plumbea; Psaltriparus minimus var. plumbeus; Psaltriparus santaritae; Psaltriparus melanotis lloydi.

Status-Abundant in Upper Sonoran and Transition zones in northern and eastern Arizona. Reported from many localities: Fort Whipple, Keam Cañon, Little Colorado River, Hualpai, Huachuca, Santa Rita, and Chiricahua mountains, etc. There are no records from the arid southwestern portion of the state, nor from the Colorado River Valley, at its western border.

348.

Auriparus flaviceps flaviceps (Sundevall).

VERDIN.

Synonym-Paroides flaviceps.

Status-Common resident of the Lower Sonoran valleys of southern and western Arizona. Occurs along the Colorado River to the extreme nortliwestern corner of the state (Beaverdam Creek, Fisher, I893b, p. I42). In eastern Arizona it is not reported from any point north of the Gila River. The northern and eastern limits of its range are formed by the rising slopes of the mountains forming the great divide which extends diagonally across the state.

\section{Regulus calendula calendula (Linnaeus).}

RUBY-CROWNED KINGLET.

Status-A summer visitant of the higher parts of the mountains of northern and central Arizona. Recorded as breeding on San Francisco Mountain, Mount Graham, and the Mogollon, White and Chiricahua mountains. Known to breed alsn in the Santa Catalina Mountains (F. C. Willard, MS). Remains through the winter in the lower valleys throughout the state. Generally distributed during the migrations.

$35 \%$

Polioptila caerulea obscura Ridgway.

WESTERN GNATCATCHER.

Synonym-Polioptila caerulea.

Status-Breeds principally in the Upper Sonoran zone. Definitely reported in summer from San Francisco Mountain, Fort Whipple, and the Hualpai Mountains, in the north; and from the Santa Catalina and Huachuca mountains in southern Arizona. In winter occurs locally in the warmer valleys of southeri Arizona (Tucson, etc.), and along the lower Colorado River, from Needles southward. 
$35 \mathrm{I}$.

Polioptila plumbea (Baird).

Plumbeous Gnatcatcher.

Synonyms-Culicizora plumbea; Polioptila melanura; Polioptila caerulea var. plumbea.

Status-Fairly common resident of the I,ower Sonoran zoile of southern, western, and parts of northern Arizona. Found breeding in all the low valleys south of the Mogollon Divide (Gila, Santa (ruz, San Pedro, etc.), north to Fort Whipple (Coues, I866a, p. 66) and Fort Moliave. Also reported in summer from Keam Cañon, in northwestern Arizona (Fisher, I903, p. 36). As it has been taken at some of the northernmost points of record in Arizona durmg the winter months, it is probably a permanent resident wherever it is found in the state, though possibly there are slight local migrations.

$35^{2}$.

\section{Myadestes townsendi (Audubon).}

TOWNSEND SOLITAIRE.

Synonym-Ptilogony's tozensendii.

Status-Breeds in the Boreal zone of the San Francisco Mountains (Merriam, I890, p. IOI) ; not known to do so elsewhere in Arizona, though it may prove to be a summer visitant in some other of the higher ranges (Mogollon Mountains, White Mountains, etc.). A pair of birds seen in the Huachuca Mountains during June, I9I0, under circumstances possibly indicative of their breeding (F. C. Willard, MS). A common migrant in the Upper Sunoran and Transition zones, observed at various points in eastern Arizona. Seen in northern Arizona in January and February (Kennerly, I859, p. 25). Has occurred through the winter in the Santa Catalina Mountains (Scott, I888, p. I67), and in the Dragoon Mountains (Osgool, I903, p. I5I).

353.

Hylocichla fuscescens salicicola Ridgway.

\section{WiLlow Thrush.}

Synonym-Turdus fascescens salicicolus.

Status-The only positive record for Arizona is that of a specimen taken by Herbert Brown at Tucson, in May, 1882 (Scott, I888, p. I67). Breninger (Igoia, p. 46) reported one as seen on the Pima Indian Reservation, south of Phoenix, in September [Ig0o?], but the bird was not taken.

354 .

Hylocichla ustulata ustulata (Nuttall).

RUSSET-BACKED THRUSH.

Synonyms-Turdus ustulatus; Hylocichla ustulata swainsoni.

Status-Although there are singularly few records of the occurrence of this species in Arizona, it is nevertheless a common migrant in the southern and western parts of the state. The published records are as follows: Santa Rita Mountains, May I7, I88I, one specimen (Brewster, I882, p. 68) ; Fort Lowell, May 2I, I884, one specimen (Brewster, I885a, p. 85) ; Yuma, May, three specimens (Morcom, 1887 , p. 57) ; Hachuca Mountains, common migrant in the spring (Swarth, Igo4b, p. 63). Re-examination of specimens recorded as $H$. $u$. swainsoni (Swarth, 1. c.) shows them all to be examples of $H$. u. ustulata. 
Kadia Hirmij 'Tirusu.

Synonyms-Turdus nanus; Hylocichla nana; T'urdus pallasi var. Hanus; Turdus maloscae; T'urdus aonalaschliae.

Status-Common migrant and winter visitant in the valleys and foothills of southern Arizona, and along the Colorado River. Verde Valley, winter (Mearns, 1890a, p. 263) ; Santa Catalina Mountains, winter (Scott, 1888, p. 167 ) ; Fort Whipple, migrant (Cones, 1866a, p. 65). It has not been reported from any point in Arizona north and east of the Mogollon Divide.

Hylooiohla guttata auduboni (Baird).

ROCKY MOUN'Ain HiRmit 'THRUSH.

Synonyms-Turdus pallasi var. andubovi; Turdus nualascac auduboni; Turdus aonalaschliac anduboni; Turdus gurtatus anduboni.

Status-Summer visitant in the higher mountains of northern and eastern Arizona. Has been found brecling on Mount Graham (Henshaw, 1875b, p. 144), the Mogollon Mountains (Mearns, 1800a, p. 263), San Francisco Mountain (Merriam, 1890, p. 101), and the Chiricahua Mountains (Fisher, 1904, p. 81 ). In the Santa Catalina Mountains Scott (1885c, p. 349) found it very ratre but apparently breeding. Reported as a migrant in the Dragoon Mountains (Osgood, 1903, p. 151), and in the Huachuca Mountains (Swarth, 1904b, p. 6.4). There are no recoreds from localities in the lowlands.

357.

Hylociolla guttata nunus (Auclubon).

DwARl Hirma' 'T'HRUsh.

Status-Apparently of rare occurrence in Arizona. The following two re. ferences are the only ones I have seen relating definitely to this subspecies: Huachuca Mountains, one specimen; April 6, 1903 (Swarth, 1904h, p. 64): "Santa Catalina Mountains, Octolser 30: . . Fort Verde, November 9; Tueson, January 17" (Ridgway, 190\%, p. 42). There is in the Museum of Vertebrate \%oology a skin (no. 6432) taken by J. G. Cooper at Fort Mohave, Jantairy 25.1861 .

358 .

Hylociohla guttata slevini Grinucll.

MON'TRLYY HERMIT 'THRUSH.

Status-A rare migrant, reported only from the Huachuea and Chiricaluat mountains (Swarth, 1904h, p. 6.4).

359.

Planestious migratorius propinquus (Riclgway).

Wrstrikn Romin.

Synonyms-Turdus migratorius; Planesticus migratorius; Turdus migraiorius propinquus; Merula migraforia propingua.

Status-Breeds commonly in most of the high mumntain ranges of eastern Arizona. Has been reported in summer from the Mogollon Mountains, San Francisco Mountain, Huachuca Mountains, and the vicinity of Fort Whipple. Winters in the valleys and lowlands generally. 
360.

Sialia sialis fulva Brewster.

Azure Bluebird.

Synonym-Sialia sialis asurea.

Status-Rare in summer in the high mountains of extreme southern Arizona: Santa Rita Mountains, June 18 and 20, 1884, three specimens (Brewster, $1885 \mathrm{a}$, p. 85) ; Huachuca Mountains (Ridgway, 1907, p. 146). The latter record, according to information received by me from Mr. W. W. Cooke, is based upon a specimen taken by Dr. A. K. Fisher, at Fort Huachuca, April 30, 1892. The species is not of regular or of conmon occurrence in either of these mountain ranges, where Sialia mexicana bairdi is the common breeding bluebird; in fact the above records are the only ones known to me, though the region has been visited frequently by collectors.

$36 \mathrm{r}$.

Sialia mexicana bairdi Ridgway.

CHESTNUT'-BACKED BLUEBIRD.

Westem

Synonyms-Sialia occidentalis; Sialia mexicana; Sialia mexicana occidentalis.

Status-Common resident in high Transition in the mountains of northern and eastern Arizona, ranging west to the Hualpai Mountains (Stephens, 1903, p. I05). Also definitely reported as occurring in summer on San Francisco Mour-tain, and in the Mogollon, Chiricahua, Santa Catalina, and Huachuca ranges. Of more general distribution during the winter: still to be found in the high ranges of southern Arizona, but in the valleys and plains also, and along the Colorado River.

362.

Sialia currucoides (Bechstein).

Mountain Bluebird.

Synonym-Sialia arctica.

Status-A summer visitant of the higher mountains north of the Mogollon Divide. Reported as breeding in the San Francisco and Mogollon mountains (Mearns, 1890a, p. 264). Occurs during the winter at Fort Whipple, along the lower Colorado River, and in the valleys of southern Arizona-Tucson, San Pedro River, etc.

\section{HYPOTHETICAL LIST}

I.

Colymbus auritus Linnaeus.

HORNED GiREBE.

Synonym-Podiceps cornutus.

Status-Known only from the records by Coues of its occurrence on the Colorado River (1866a, p. 100), and at Fort Grant (1868, p. 84), statements which are not sufficiently explicit. 


\section{PACIFIC LOON.}

Synonyms-Colymbus pacificus; Colymbus arcticus var. pacificus.

Status-The only reason for including this species in a list of the birds of Arizona lies in the fact that it is contained in Cones' "List of the Birds of Fort Whipple" ( I866a, p. I00). No specific instance of its occurrence is cited, however; in fact he does not even explicitly state that the species was found in the region, and though it may occur in winter on the Colorado River, there is at present no proof that such is the case.

Larus occidentalis Autubon.

Wisterrn Gull.

Status-Recorded as seen commonly in midwinter along the Colorado River from its mouth to a point forty miles south of Yuma (Price, I899, p. 90). If no mistake was made in identification the species may be found ranging up the river to within the Arizona boundary.

4.

\section{Larus heermanni Cassin.}

HEERMANN GULL.

Status-Seen by Rhoads, in winter, on the lower Coloracio River, "as far up as Yuma, Arizona" (Stone, I905, p. 687). 'The improbability of the occurrence demands the verification of specimens actually secured.

5 .

Larus atricilla Linnaeus.

Laughing Gull.

Synonym-Chroecocephalus atricilla.

Status-"Colorado River, particularly its lower portions. A specimen taken over a hundred miles from any body of water, near the eastern border of the 'Territory" (Cones. I866a, p. 99). This is the only Arizona record.

6.

Larus franklini Richardson.

\section{FrankLIN Gür..}

Synonym-Chroecoccphalus franklini.

Status-"I am under the impression that I also saw Ch. franklinii about twenty miles from the river near Fort Mojave" (Cones, 1866a, p. 99).

7.

\section{Branta bernicla glaucogastra (Brehm).}

BRANT.

Synonym-Bernicla brenta.

Status--Mentioned by Coues ( $1865 \mathrm{~b}$, p. $53^{8}$ ) as occurring on the Gila River, and by Woodhouse (I853, p. I02) as abundant in "New Mexico". Both statements seem improbable.

8.

\section{Guara rubra (Linnaeus).}

SCARLFi I IBIS.

Status-Known only from the record of a flock of seven or eight birds, supposedly this species, seen at Rillito Creek, near Fort Lowell. September I7, I890 (Brown, s899a, p. 270). 
9.

Creciscus jamaicensis (Gmelin).

BLACK RAIL.

Synonym-Porzana jamaicensis.

Status-Doubtfully recorded from the vicinity of Tucson, on the basis of a bird, believed to be of this species, seen April 23, I88I (Brewster, I883, p. 36).

Io.

Limosa fedoa (Linnaeus).

Marbled Godwit.

Status-A bird supposed to be of this species seen, but not secured, on the San Pedro River, January 27, I886 (Scott, I886, p. 386).

I I.

Limosa haemastica (Linnaeus).

Hudsonian Godwit.

Status-Its occurrence in the state can not be considered as established by the record of the observation of a bird "probably of this species" (Visher, I9rob, p. 280).

I2.

Totanus flavipes (Gmelin).

YELLOWLEGS.

Status-One record, of its occurrence near Tucson, in September (Visher, rgrob, p. 280). In the absence of specimens it may be questioned.

I3.

Charadrius dominicus dominicus Müller.

Golden Plover.

Status-The only record is that of two seen, but not secured, near Tucson (Visher, 19Iob, p. 28I ).

I4.

Columba flavirostris Wagler.

RED-PILLED Pigenon.

Status-Known only from the record by Bendire (I892, p. I28) of three birds (not seen by himself) said to have been shot in the foothills of the Graham Mountains, near Fort Grant, July 25, 1886.

I5.

Gymnogyps californianus (Shaw).

California Condor.

Synonyms-Cathartes californianus; Pseudogryphus califoruianus.

Status-"Resident in Southern Arizona. Indivicluals observed at Fort Yuma in September, I865" (Coues, I866a, p. 42). The statement as to its occurrence in southern Arizona lacks confirmation; Fort Yuma is on the California side of the river. There are doubtful records of its occurrence in the Santa Catalina Mountains (Rhoads, I892, p. I I4), and at Pierce's Ferry, Colorado River ' northwest Arizona), in March, I88I (Brown, I899b, p. 272).

I6.

Sarcoramphus papa (Linnaeus).

King Vuliure.

Synonym-Gyparchus papa.

Status - The very doubtful records of its occurrence on San Francisco i2iver (Coues, I866a, p. 49), and the Verde River (Coues, I88Ib, p. 248) lack confirmation. 
I 7 .

Elanus leucurus (Vieillot).

WHITE-TAILED KITE.

Status-The only definite record for Arizona is that of F. T. Pember, who claimed to have met with the species near Gila Bend, in April (I892, p. 49). I8.

\section{Buteo lineatus elegans Cassin.}

RED-BELLIED HAWK.

Synonym-Buteo elegans.

Status-The only record of the occurrence of this species in Arizona is the.t of a specimen collected by Kennerly and Mollhausen on the Colorado Chiquito, November I7, I853 (Baird, 1858, p. 28). According to information receiveil by me from Mr. W. W. Cooke it is not now to be found in the National Ivíuseum collection, although entered in the catalogue, with data as given above. Under the circumstances the species may be excluded from the regular list until tine occurrence can be confirmed.

\section{Xenopicus albolarvatus (Cassin).}

WHITE-HEADED WOODPECKFR.

Status-The alleged occurrence of this species in the Santa Catalina Mountains (Visher, I9lob, p. 282) seems doubtful.

20.

Otocoris alpestris praticola Henshaw.

Pratrie Horned Lark.

Status-One specimen recorded from Fort Verde, in winter (Oberholser, 1902, p. 825). The possibility presents itself of this bird being an individual extreme of some one of the several races regularly frequenting the region, or an intergrade between two of them, rather than belonging to the race to which it has been referred. In treating slightly differentiated subspecies of such a variable species it seems unsafe to assert such an extraordinary extension of range on such slender evidence.

2 I.

\section{Agelaius phoeniceus californicus Nelson.}

\section{BICOLORED RED-WINGE্D BLACKBIRD.}

Synonym-Agelaius gubernator californicus.

Status-Straggling east to western Arizona (A. O. U. Check-List, 1910, p. 235). According to information receiver by me from Mr. W. W. Cooke, this statement is based upon a specimen found dead July 6, 1907, by Mr. Vernoul Bailey, at Casa Grande. Intergradation between this form and neutralis has been demonstrated, and the possibility suggests itself of the supposed specimen of californicus being really an individual extreme of ncutralis, a common species in the region. The occurrence of californicus, apparently a non-migratory form, so far from the normal boundaries of its range, should receive the strongest possible verification.

22.

Wilsonia pusilla pusilla (Wilson).

WILSON WARBLER.

Status-According to Ridgway (IgO2, p. 710 ) this species is "occasional during migration in . ... Arizona (Tucson, May: Fort Whipple, May)". 
23.

\section{Regulus satrapa satrapa Lichtenstein.}

Golden-Crowned Kinglest.

\section{Synonym-Regulus satrapa olivaceus.}

Status-Most of the statements relative to the occurrence of this species in Arizona can be traced back to Woodhouse's casual mention of birds seen on Sa11 Francisco Mountain (1853, pp. 67,68). In the absence of specimens, and of subsequent confirmation by other observers, it seems best to exclude the species from the regular list. A recent record from the Santa Catalina Mountains, in July (Rhoads, 1892, p. 125), can not be considered as satisfactory, as specimens were not secured.

24.

Ixoreus naevius naevius (Gmelin).

VARIED THRUSH.

Synonym-Turdus naerius.

Status-Said to have been obtained by Lieut. Ives' expedition on the Colorado River between Forts Mohave and Yuma (Baird, 1861, p. 5). This may or may not have been on the Arizona side of the river, and on this account alone the species may be omitted from the Arizona list. At most it can be but an exceedingly rare straggler into the region.

\section{AN ANALYSIS OF THE AVIFAUNA OF ARIZONA}

From the foregoing data the birds occurring in the state of Arizona may be divided into the following classes:

$\begin{array}{lr}\text { Resident } & \text { I } 52 \\ \text { Summer visitant } & 72 \\ \text { Winter visitant } & 57 \\ \text { Transient } & 30 \\ \text { Of castual occurrence } & 5 \mathrm{I}\end{array}$

giving a total of 362 species and subspecies found within the state.

\section{RESIDENT SPECIES}

1. Mergus americanus

2. Anas platyrhynchos

3. Chanlelasmus streperus

4. Mareca americana

5. Querquedula discors

6. Querquedula cyanoptera

7. Spatula clypeata

8. Dafila acuta

9. Erismatura jamaicensis

10. Botaurus lentiginosus

11. Ardea herodias treganzai

12. Butorides virescens anthonyi

13. Nycticorax nycticorax naevius

14. Grus mexicana

15. Porzana carolina

16. Gallinula galeata

17. Fulica americana

18. Actitis macularius

19. Oxyechus vociferus
20. Colinus ridgwayi

21. Callipepla squamata

22. Lophortyx gambeli

23. Cyrtonyx montezumae mearnsi

24. Dendragapus obscurus obscurus

25. Meleagris gallopavo merriami

26. Columba fasciata fasciata

27. Zenaidura macroura marginella

28. Chaemepelia passerina pallescens

29. Scardafella inca

30. Cathartes aura septentrionalis

31. Circus hudsonius

32. Accipiter velox

33. Accipiter cooperi

34. Parabuteo unicinctus harrisi

35. Buteo borealis calurus

36. Buteo abbreviatus

37. Urubitinga anthracina

38. Aquila chrysaëtos 
39. Haliæetus leucoceplialus leucocephalus

40. Falco mexicanus

41. Falco peregrinus anatum

42. Falco fusco-caerulescens

43. Falco sparverius sparverius

44. Polyborus cheriway

45. Aluco pratincola

46. Strix occidentalis huachucae

47. Cryptoglaux acadica acadica

48. Otus asio cineraceus

49. Otus asio gilmani

50. Bubo virginianus pallescens

51. Speotyto cunicularia hypogæa

52. Glaucidium gnoma pinicola

53. Glaucidium phaloenoides

54. Micropallas whitneyi

55. Geococcyx californianus

56. Dryobates villosus leucothorectis

57. Dryobates pubescens homorus

58. Dryobates scalaris cactophilus

59. Dryobates arizonae

60. Picoides americanus dorsalis

61. Sphyrapicus thyroideus

62. Melanerpes formicivorus aculeatus

63. Asyndesmus lewisi

64. Centurus uropygialis .

65. Colaptes cafer collaris

66. Colaptes chrysoides mearnsi

67. Phalaenoptilus nuttalli nuttalli

68. Acronautes melanoleucus

69. Calypte costae

70. Tyrannus vociferans

71. Myiarchus cinerascens

72. Sayornis sayus

73. Sayornis nigricans

74. Pyrocephalus rubinus mexicanus

75. Otocoris alpestris adusta

76. Otocoris alpestris pallida

77. Otocoris alpestris occidentalis

78. Cyanocitta stelleri diademata

79. Aphelocoma woodhousei

80. Aphelocoma sieberi arizonae

81. Perisoreus canadensis capitalis

82. Corvus corax sinuatus

83. Corvus cryptoleucus

84. Corvus brachyrhynchos hesperis

85. Nucifraga columbiana

86. Cyanocephalus cyanocephalus

87. Molothrus ater obscurus

88. Xanthocephalus xanthocephalus

89. Agelaius phoeniceus sonoriensis

90. Agelaius phoeniceus neutralis

91. Sturnella magna hoopesi

92. Sturnella neglecta

93. Euphagus cyanocephalus

94. Hesperiphona vespertina montana

95. Carpodacus cassini

96. Carpodacus mexicanus frontalis
97. Loxia curvirostra stricklandi

98. Passer domesticus

99. Astragalinus tristis pallidus

100. Astragalinus psaltria hesperophilus

101. Spinus pinus

102. Poocetes graminets confinis

103. Passerculus sandwichensis nevadensis

104. Ammodranus savannarum bimaculatus

105. Chondestes grammacus strigatus

106. Spizella passerina arizonae

107. Spizella breweri

108. Junco phaeonotus palliatus

109. Junco phaeonotus dorsalis

110. Amphispiza bilineata deserticola

111. Aimophila carpalis

112. Aimophila ruficeps scotti

113. Melospiza melodia saltonis

114. Pipilo maculatus montanus

115. Pipilo fuscus mesoleucus

116. Pipilo aberti

117. Cardinalis cardinalis superbus

118. Pyrrhuloxia sinuata sinuata

119. Phainopepla nitens

120. Lanius ludovicianus excubitorides

121. Vireo huttoni stephensi

122. Peucedramus olivacens

123. Dendroica auduboni auduboni

124. Cinclus mexicanus unicolor

125. Mimus polyglottos leucopterus

126. Toxostoma curvirostrc palmeri

127. Toxostoma bendirei

128. Toxostoma lecontei iecontei

129. Toxostoma crissale

130. Heleodytes brunneicapillus couesi

131. Salpinctes obsoletus obsoletus

132. Catherpes mexicanus conspersus

133. Thryomanes bewicki eremophilus

134. Troglodytes aedon parkmani

135. Telmatodytes palustris plesius

136. Certhia familiaris montana

137. Sitta carolinensis nelsoni

138. Sitta canadensis

139. Sitta pygmaea pygmaea

140. Bacolophus inornatus griseus

141. Bacolophus wollweberi

142. Penthestes sclateri

143. Penthestes gambeli gambeli

144. Psaltriparus plumbeus

145. Auriparus flaviceps flaviceps

146. Regulus calendula calcndula

147. Polioptila caerulea obscura

148. Polioptila plumbea

149. Myadestes townsendi

150. Planesticus migratorius propinquus

151. Sialia mexicana bairdi

152. Sialia currucoides 
These species are resident in the sense that the available data seems to show that they occur somewhere in the state at all times of the year. Many of thein are truly migratory, and, in making altitudinal migrations, spend the summer and winter in as widely different surroundings as if they had travelled instead over the length of the continent. Some are almost entirely restricted to the warm valleys of the lower parts of the Colorado and Gila rivers during the winter.

From the list of residents may be selected the following species which are probably to be found over the same grounds the year through, though some of them may, in fall and winter, spread out over a somewhat wider territory.

Colinus ridgwayi

Callipepla squamata

Lophortyx gambeli

Cyrtonyx m. mearnsi

Dendragapus o. obscurus

Meleagris g. merriami

Buteo b. calurus

Bubo v. pallescens

Speotyto c. hypogaea

Geococcyx californianus

Dryobates v. leucothorectis

Dryobates s. cactophilus

Dryobates arizonae

Picoides a. dorsalis

Centurus uropygialis

Colaptes c. mearnsi

Otocoris a. adusta

Otocoris a. pallida

Cyanocitta s. diademata

Aphelocoma woodhousei

Aphelocoma s. arizonae

Pcrisoreus c. capitalis
Passer domesticus

Junco p. palliatus

Junco p. dorsalis

Aimophila r. scotti

Melospiza m. saltonis

Pipilo m. montanus

Pipilo f. mesoleucus

Pipilo aberti

Vireo h. stephensi

Toxostoma c. palmeri

Toxostoma bendirei

Toxostoma 1. lecontei

Toxostoma crissale

Heleodytes b. couesi

Salpinctes o. obsoletus

Catherpes $\mathrm{m}$. conspersus

Thryomanes b. ercmophilus

Sitta p. pygmaea

Baeolophus wollweberi

Psaltriparus plumbeus

Auriparus f. flaviceps

Polioptila plumbea

\section{SUMMER VISITANTS}

1. Colymbus nigricollis californicus

2. Plegadis guarauna

3. Mycteria americana (not known to breed)

4. Melopelia asiatica trudeaui

5. Buteo albicaudatus sennetti

6. Buteo swainsoni

7. Asturina plagiata

8. Otus trichopsis

9. Otus flammeolus

10. Coccyzus americanus occidentalis

11. Trogon ambiguus

12. Antrostomus vociferus macromystax

13. Chordeiles virginianus henryi

14. Chordeiles acutipennis texensis

15. Eugenes fulgens

16. Cyanolaemus clemencix

17. Archilochus alexandri

18. Sclasphorus platycercus
19. Basilinna leucotis

20. Cynanthus latirostris

21. Tyrannus verticalis

22. Myiodynastes luteiventris

23. Myiarchus magister magister

24. Myiarchus lawrencei olivascens

25. Nuttallornis borealis

26. Myiochanes pertinax pallidiventris

27. Myiochanes richardsoni richardsoni

28. Empidonax difficilis difficilis

29. Empidonax trailli trailli

30. Empidonax fulvifrons pygmaeus

31. Camptostoma imberbe

32. Tangavius aeneus aeneus

33. Icterus parisorum

34. Icterus cucullatus nelsoni

35. Icterus bullocki

36. Zonotrichia leucophrys leucophrys

37. Spizella atrogularis 
38. Peucaea botterii

39. Peucaea cassini

40. Zamelodia melanocephala melanocephala

41. Guiraca caerulea lazula

42. Passerina amoena

43. Piranga ludoviciana

44. Piranga hepatica

45. Piranga rubra cooperi

46. Progne subis subis

47. Petrochelidon lunifrons lunifrons

48. Petrochelidon lunifrons melanogastra

49. Hirundo erythrogastra

50. Tachycineta thalassina lepida

51. Riparia riparia

52. Stelgidopteryx serripennis

53. Vireosylva gilva swainsoni

54. Lanivireo solitarius plumbeus

55. Vireo belli arizonae
56. Vireo vicinior

57. Vermivora luciæ

58. Vermivora virginix

59. Vermivora celata celata

60. Dendroica aestiva sonorana

61. Dendroica auduboni nigrifrons

62. Dendroica graciæ

63. Dendroica nigrescens

64. Oporornis tolmiei

65. Geothlypis trichas scirpicola

66. Icteria virens longicauda

67. Wilsonia pusilla pileolata

68. Setophaga picta

69. Cardellina rubrifrons

70. Certhia familiaris albescens

71. Hyiocichla guttata auduboni

72. Sialia sialis fulva

For comments upon the species included in this list see beyond, under the discussion of the composition of the avifauna of the different life zones within the state.

\section{WIN'TER VISI'TAN'TS}

1. Aechmophorus occidentalis

2. Podilymbus podiceps

3. Gavia immer

4. Phalacrocorax auritus albociliatus

5. Pelecanus erythrorhynchos

6. Mergus serrator

7. Nettion carolinense

8. Marila americana

9. Marila valisineria

10. Marila marila

11. Marila affinis

12. Charitonetta albeola

13. Chen hyperboreus hyperboreus

14. Anser albifrons gambeli

15. Branta canadensis canadensis

16. Branta canadensis hutchinsi

17. Dendrocygna bicolor

18. Olor columbianus

19. Grus canadensis

20. Rallus virginianus

21. Recurvirostra americana

22. Gallinago delicata

23. Pisobia minutilla

24. Ereunetes mauri

25. Podasocys montanus

26. Archibuteo ferrugineus

27. Falco columbarius columbarius

28. Asio wilsonianus

29. Asio flammeus
30. Ceryle alcyon

31. Sphyrapicus varius nuchalis

32. Otocoris alpestris leucolaema

33. Agelaius phoeniceus fortis

34. Astragalinus lawrencei

35. Calcarius ornatus

36. Rhynchophanes mccowni

37. Passerculus sandwichensis alaudinus

38. Ammodramus bairdi

39. Zonotrichia leucophrys gambeli

40. Junco hyemalis hyemalis

41. Junco oreganus thurberi

42. Junco oreganus shufeldti

43. Junco mearnsi

44. Junco caniceps

45. Amphispiza nevadensis nevadensis

46. Melospiza melodia fallax

47. Melospiza lincolni lincolni

48. Passerella iliaca schistacea

49. Pipilo maculatus curtatus

50. Oreospiza chlorura

51. Calamospiza melanocorys

52. Bombycilla cedrorum

53. Geothlypis trichas occidentalis

54. Anthus rubescens

55. Oreoscoptes montanus

56. Hylocichla guttata guttata

57. Hylocichla guttata nanus 
Most of these are migratory species which spend the summer at varying distances directly to the northward, and it is to be expected, of course, that they should occur in winter in this state. The occurrence of Junco o. thurberi and Hylocichla $g$. namus is further evidence of the existence of a migration route across the deserts to the westward, as shown by the various Pacific Coast birds m1grating through Arizona.

\section{T'ransient Species}

1. Herodias egretta

2. Egretta candidissima candidissima

3. Steganopus tricolor

4. Himantopus mexicanus

5. Pisobia bairdi

6. Totanus melanoleucus

7. Helodromas solitarius cinnamomeus

8. Numenius americanus

9. Aegialitis semipalmata

10. Pandion haliaetus carolinensis

11. Chaetura vauxi

12. Selasphorus rufus

13. Stellula calliope

14. Empidonax hammondi

15. Empidonax wrighti
16. Empidonax griseus

17. Spizella pallida

18. Passerina ciris

19. Spiza americana

20. Iridoprocne bicolor

21. Lanivireo solitarius cassini

22. Vermivora rubricapilla gutturalis

23. Vermivora celata lutescens

24. Dendroica aestiva brewsteri

25. Dendroica townsendi

26. Dendroica occidentalis

27. Seiurus noveboracensis notabilis

28. Wilsonia pusilla chryseola

29. Hylocichla ustulata ustulata

30. Hylocichla guttata slevini

The thirty species listed above occur, as far as we know, merely as migrants, passing through Arizona on their way to and from their breeding grounds, neither nesting nor wintering anywhere within the state. Twelve of these species spend the summer on the Pacific coast in California or farther north, and their abundance during the migrations indicates the presence of a well defined migration route from southeast Arizona almost due westward and across the intervening deserts. These species are: Chaetura zauxi, Selasphorus rufus, Stellula calliope, Empidona. hammondi. Lanivireo s. cassini, Vermivora r. gutturalis. Vermivora c. lutescens, Dcndroica townsendi. Dendroica occidentalis, Wilsonia p. chryseola, Hylocichla u. ustulata, and Hylocichla g. slevini.

Five of the species listed breed in the far north, and pass through Arizona in the course of a direct north and south migration. These are: Pisobia bairdi, Totanus melanoleucus. Helodromas s. cinnamoncus, Aegialitis semipalmata. Seiurus n. notabilis. Four other species breeding at nearer points north of Arizona, and hence following the same migration route through the state, are: Steganopus tricolor, Himantopus mericanus, Numenius americanus, Dendroicu a. brewsteri.

Spizella pallida, Passerina ciris, and Spiza americana are species from regions east of Arizona whose manner of occurrence, usually in the late summer, is apparently indicative of established migration routes. Of the remaining six species on the list of migrants. Hcrodias egretta, Egretta c. candidissima, Pandion h. carolinensis, Empidnna.x aurighti, Empidona.x griseus, and Iridoprocne bicolor, it may be that some or all will be found breeding within the state, but the data available at the present time shows their presence only during the period of migration. 
I. Gavia stellata

2. Larus delawarensis

3. Larus philadelphia

4. Sterna forsteri

5. Sterna hirundo

6. Hydrochelidon nigra surinamensis

7. Phaëthon aethereus

8. Anhinga anhinga

9. Lophodytes cucullatus

10. Clangula clangula americana

11. Dendrocygna autumnalis

12. Ixobrychus exilis

13. Rallus levipes

14. Coturnicops noveboracensis

15. Ionornis martinicus

16. Lobipes lobatus

17. Macrorhamphus griseus scolopaceus

18. Pelidna alpina sakhalina

19. Catoptrophorus semipalmatus inornatus

20. Bartramia longicauda

21. Astur atricapillus atricapillus

22. Archibuteo lagopus sanctijohannis

23. Falco columbarius richardsoni

24. Rhynchopsitta pachyrhyncha

25. Crotophaga sulcirostris

26. Ceryle americana septentrionalis

That this list is of such length is undoubtedly largely due to the defective data at our command; and many of the species included may prove to be of fairly common, or at any rate regular, occurrence, at some season of the year. Of certain of them, however, the individuals taken were evidently beyond the normal bounds of the species. These are: Phaëthon acthereus, Rallus levipes, Crotophaga sulcirostris, Ceryle a. septentrionalis, Melanerpes erythrocephalus, Platypsaris a. albiventris, Zamelodia ludoviciana. Passerina ¿. pulchra, Lanius borealis. Vireosylva olivacea, Protonotaria citrea, Dendroica virens. Setophaga ruticilla, Toxostoma rufum, Nannus h. pacificus, Hylocichla f. salicicolus.

Each of the above is admitted to the state list of birds on the basis of the capture of at least one specimen, but it is not to be expected that the species prove to be of regular occurrence.

Two others, Calypte anna and Selasphorus alleni, have occurred with sufficient frequency to have entitled them, perhaps, to a place in the category of migrants. but the present definition seems to best express their manner of occurrence, late summer wanderers, and rot travelers to a determined destination.

\section{Specirs OCCURrixg in the Lower SONORAN 7.ONF}

1. Melopelia a. trudeaui

2. Buteo a. sennetti

3. Buteo swainsoni

4. Asturina plagiata

5. Chordeiles a. texensis

6. Tyrannus verticalis

7. Myiarchus $m$. magister

8. Empidonax t. trailli

9. Camptostoma imberhe

\section{SUMMER VISITANT}

10. Tangavius a. aeneus

11. Icterus c. nelsoni

12. Peucaea botterii

13. Peucaea cassini

14. Guiraca c. lazula

15. Piranga $r$. cooperi

16. Vireo b. arizonae

17. Vermivora luciae

18. Dendroica a. sonorana 



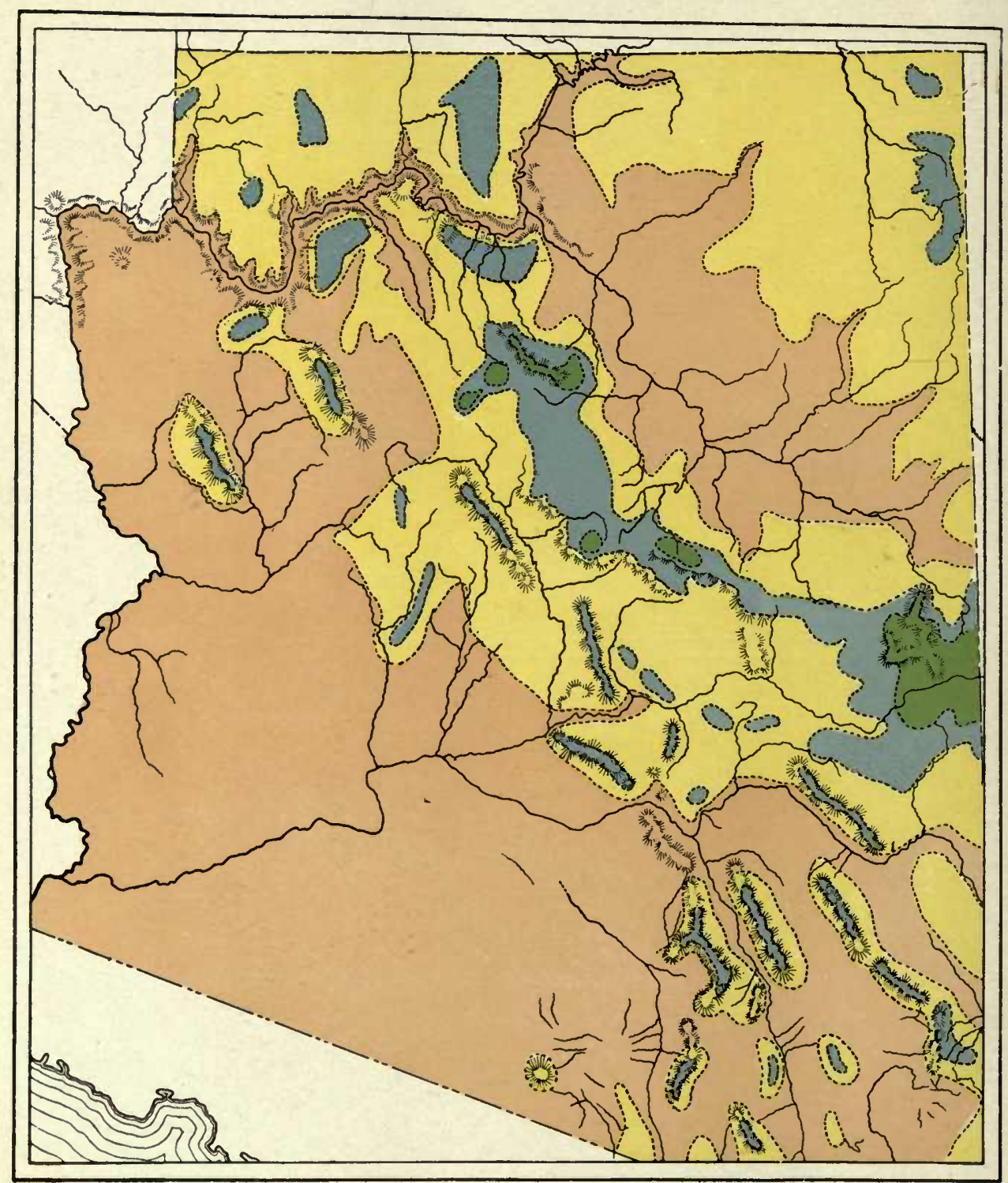

$\square$ LOWER SONORAN $\square$ UPPER SONORAN $\square$ TRANSITION $\square$ BOREAL 
RESIDENT

1. Colinus ridgwayi

2. Callipepla squamata

3. Lophortyx gambeli

4. Chaemepelia p. pallescens

5. Scardafella inca.

6. Parabuteo u. harrisi

7. Falco fusco-caerulescens

8. Polyborus cheriway

9. Otus a. gilmani

10. Speotyto c. hypogaea

11. Glaucidium phaloenoides

12. Micropallas whitneyi

13. Geococcyx californianus

14. Dryobates s. cactophilus

15. Centurus uropygialis

16. Colaptes c. mearnsi

17. Calypte costae

18. Sayornis sayus

19. Pyrocephalus r. mexicanus
26. Otocoris a. adusta

21. Otocoris a. pallida

22. Corvus cryptoleucus

23. Molothrus a. obscurus

24. Amphispiza b. deserticola

25. Aimophila carpalis

26. Melospiza m. saltonis

27. Pipilo aberti

28. Cardinalis c. superbus

29. Pyrrhuloxia s. sinuata

30. Phainopepla nitens

31. Toxostoma c. palmeri

32. Toxostoma bendirei

33. Toxostoma 1. lecontei

34. Toxostoma crissale

35. Heleodytes b. conesi

36. Auriparus f. flaviceps

37. Polioptila plumbea

The Lower Sonoran zone occupies a larger portion of the state than aniy other of the faunal subdivisions. It inclucies the vast desert area of western Arizona, and extends as long, narrow ribbons far up the valleys of the Gila River and its tributaries, and along the Colorado River to, and including, the desert of the Little Colorado River, in the northeastern corner of the state. In these Lower Sonoran valleys of Arizona many of the distinctive southwestern desert types attain their greatest development. The group of thrashers is a gond example of this class; while there are distinctive low zone species of doves, quails, and woodpeckers, several species of each, with great abundance of individuals.

The various associations found within the Lower Sonoran zone present combinations of species quite as distinctive as those inhabiting different zones. Among these may be mentioned the association of the mesquite-bordered streams, in which are found the White-winged Dove, Vermilion Flycatcher, Crissal Thrasher, Lucy Warbler, Sonoran Yellow Warbler and Verdin; that of the giant cactus, with the Sahuaro Screech Owl, Elf Owl, Gilded Flicker, and Arizona Crested Flycatcher; and that of the creosote and cholla cactus covered mesa, with the Black-throated Sparrow, Palmer, Bendire and Leconte thrashers, Cactus Wren, Plumbeous Gnatcatcher and Texas Nighthawk. These lists, of course, are not at all complete, but include merely some of the most conspicuous and typical birds of each association. The subject is deserving of careful study, such as cannot be attempted in this connection, and should include consideration of the mammals and reptiles of the regions as well as of the birds. Many of the correlations noted even in a cursory survey of the available data, are extremely interesting.

Specips Occurring in the Upper Sonoran Zone SUMMER VISITANT

1. Cynanthus latirostris

2. Myiarchus 1. olivascens

3. Myiochanes r. richardsoni
4. Icterus patisorum

5. Vireosylva g. swainsoni

6. Vireo vicinior 


\section{RESIDENT}

1. Otus a. cineraceus

2. Dryobates arizonae

3. Melanerpes f. aculeatus

4. Tyrannus vociferans

5. Aphelocoma woodhousei

6. Aphelocoma s. arizonae
7. Aimophila r. scotti

8. Vireo h. stephensi

9. Baeolophus i. griseus

10. Baeolophus wollweberi

11. Polioptila c. obscura

The Upper Sonoran zone occupies a comparatively limited area in the state, and the list of birds confined to it solely is a short one. In southern Arizona this zone is in few places of greater width than is comprised in the belt of live-oak covered foothills between the higher mountains and the valleys below. Of the seventeen species listed as peculiar to this zone, eleven are preeminently birls of this live-oak association, as follows: Otus a. cineraceus, Dryobates arizonae, Melancrpes $f$. aculeatus, Tyrannus zociferans, Myiarchus l. olivascens, Aphelocoma woodhousci, Aphelocoma s. arizonae, Vireo h. stephensi, Bacolophus $i$. griseus, Baeolophus wollweberi, Polioptila c. obscura.

Of the remaining six, Cynanthus latirostris, Myiochanes $r$. richardsoni, and Vireosylza g. swainsoni are to a great extent denizens of the sycamores along the cañon streams in the foothills, Icterus parisorum and Aimophila ruficeps scotti frequent the agave and scrub-oak covered hillsides, while Vireo incinior. is in the denser brush of the same region.

Species in the Transition Zone and Higher, more nearly Rlilated to the Rocky Mountain Fatna to the Northward

SUMMER VISITANT

1. Chordeiles v. henryi

2. Nuttallornis borealis

3. Zonotrichia 1. leucophrys

4. Zamelodia m. melanocephala

5. Piranga ludoviciana

6. Tachycineta t. lepida

7. Lanivireo s. plumbeus
8. Vermivora virginiæ

9. Dendroica a. auduboni

10. Dendroica graciæ

11. Dendroica nigrescens

12. Wilsonia p. pileolata

13. Hylocichla g. auduboni

\section{RESIDENT}

1. Dendragapus o. obscurus

2. Columba f. fasciata

3. Aquila chrysaëtos

4. Strix o. huachucae

5. Cryptoglaux a. acadica

6. Glaucidium g. pinicola

7. Dryobates v. leucothorectis

8. Picoides a. dorsalis

9. Sphyrapicus thyroideus

10. Cyanocitta s. diademata

11. Perisoreus c. capitalis

12. Nucifraga columbiana

13. Hesperiphona v. montana

14. Carpodacus cassini
15. Loxia c. stricklandi

16. Spinus pinus

17. Pipilo m. montanus

18. Troglodytes a. parkmani

19. Certhia f. montana

20. Sitta canadensis

21. Sitta p. pygmaea

22. Penthestes g. gambeli

23. Regulus c. calendula

24. Myadestes townsendi

25. Planesticus $m$. propinquus

26. Sialia m. bairdi

27. Sialia currucoides 
Stpecies in the Transition Zone and Higher, more nearly Related to the Mexican Plateau Fauna to the Southward.

SUMMER VISITANT

1. Otus trichopsis

2. Otus flammeolus

3. Trogon ambiguus

4. Antrostomus v. macromystax

5. Eugenes fulgens

6. Cyanolaemus clemenciæ

7. Myiodynastes luteiventris

1. Cyrtonyx m. montezumae

2. Meleagris g. merriami

3. Junco p. palliatus
8. Myiochanes p. pallidiventris

9. Empidonax f. pygmaeus

10. Piranga hepatica

11. Dendroica a. nigrifrons

12. Setophaga picta

13. Cardellina rubrifrons

14. Certhia f. albescens

\section{RESIDENT}

Dividing the sixty species occurring in the Transition zone and higher into two groups we find that there are forty which are the same as, or closely related to, species occurring to the northward, in the Rocky Mountains or in the Sierra Nevada of California, and twenty which are the same as, or most closely related to, Mexican forms.

Many of the first mentioned group find their southern linit in northern or central Arizona. some extend to southern Arizona, anci about half the list occur southward onto the plateau region of northern Mexico. A division of this group into summer visitants and residents results in thirtecn of the former and twentyseven of the latter. From these relative numbers it is cviclent that the birds of the high mountains of northern and central Arizona are mostly species at the southernmost extension of their ranges, indicating, in fact, the sonthern limit of the Rocky Mountain avifauna.

Now turning to the species of Mexican affinities we find conditions reversed, in that of the twenty forms listed, fourteen are summer visitants, while only six are resident. These birds, of tropical derivation, are here at their northernmost limits, and but a small proportion of them can endure the winter climate of this latitude. Of the fourtcen summer visitants all but one extend only into the southern half of Arizona, many of them but an extremely short distance north of the southern boundary of the state.

A great difference in the bird life of the higher zones of northern and southern Arizona is that while in the former region a great part of the population is resident, in the latter most of the species depart during the winter months. The highest parts of the mountains of southern Arizona are noticeably deficient of bird life in winter, and many of the birds seen at this time belong to species nesting farther north in the state, which occur here in winter only.

In general it may be said of the avifalina of the high mountains of Arizona, that the ranges of the northern part of the state are more nearly like the Rocky Mountains to the northward, and the northern Sierra Nevada, while the southern mountain chains bear a somewhat closer resemblance to the mountains of southern California. In the northern and central parts of the state we find such species as Dendragapus obscurus, Picoides a. dorsalis, Perisoreus c. capitalis, Zonotrichia 
leucophrys and Hylocichla g. auduboni. While the distinctive feature of the southern mountain chains is, of course, the strikingly large element of Mexican species, many of them distinctly subtropical, such as Cyrtonyx m. mearnsi, Dryobates arizonae, Pencedramus olivaceus, Cardellina rubrifrons, Trogon ambiguus, and the numerous species of hummingbirds, there are besides these, many others closely related to southern California forms. In this class may be mentioned Strix o. huachncac, Melanerpes f. aculeatus, Aimophila r. scotti, Pipilo $f$. mesolencus, Vireo h. stephensi, Sitta pygnaca, and Baeolophus i. griseus. Of these the Strix, Aimophila, and Vireo are of peculiar interest, for although but slightly distinguished from their California relatives, the habitats of the Pacific Coast and Arizona representatives are so widely separated that there is no possibility of their joining at any point. These birds must be treated as subspecies rather than species on the ground of the slight degree of difference between the races, for they are resident wherever they occur, and from the manner in which they are isolated in comparatively limited areas of Upper Sonoran and Transition in the vast surrounding extent of Lower Sonoran desert, there is no possibility of continuity of range with their closest allies.

To sum up, it thus appears that the bird life of the higher mountains of Arizona is a rather curious composite, of more northern Rocky Mountain forms extending southward, and of the southern, Mexican plateau forms extending northward, the two faunas meeting, and to a certain extent interdigitating. Added to these are other species, probably of southern derivation, closely allied to Facific Coast races but entirely isolated from them. Somewhat similar conclusions were reached by Mearns in a paper on the avifauna of the mountains of central Arizona (1890, pp. 45-50), but with an assumption of more continuous connection of the Arizona mountains with the Sierras of central California than seems to exist.

\section{BIBLIOGRAPHY}

\section{List of Publications Relating to Arizona Ornithology}

The titles are arranged chronologically. Inder each year the authors are entercd in alphabctical order, and the works of each listed chronologically in order of publication. The brief explanatory notes appended aim to assist to a clear idea of the scope and cliaracter of a book or paper when such is not apparent from the title, and also to call attention to any point of particular interest in connection with the present publication.

I843. Gambel, W. Descriptions of some new and rare Birds of the Rocky Mountains and California. < Proc. Acad. Nat. Sci. Phila., I, I843, pp. 259-262.

1853. Woodhouse, S. W. Report of an Expedition down the Zuni and Colorado Rivers, by Captain L. Sitgreaves, Corps Topographical Enginecrs. Accompanied by Maps, Sketches, Views, and Illustrations. Washington: Robert Armstrong, Public Printer. 1853. 8vo, pp. I-I98, 77 pls., map. > Birds. By S. W. Woodhouse, M. D. Pp. 58-105, pls. I, III-VI. 
1854. Baircl, S. F. Descriptions of New Birds collected between Albuquerque, N. M., and San Francisco, California, during the Winter of 1853-54, by Dr. C. B. R. Kennerly and H. B. Möllhausen, naturalists attached to the survey of the Pacific R. R. Route, under Lt. A. W. Whipple. < Proc. Acad. Nat. Sci. Phila., June, 1854, pp. I I8-I 20.

Cypselus ( $=$ Aeronantes) melanoleucus; Culicivora ( = Polioptila) plumbea, Psaltria ( = Psaltriparns) plumbeus; Carpodacus cassini; Zonotrichia fallax ( $=$ Melospiza melodia fallax); Pipilo mesoleucus; Centurus uropygialis; all described from localities in Arizona.

1854. Heermann, A. L. Additions to North American Ornithology, with descriptions of new species of the genera Actidurus, Podiceps and Podylymbus. <Proc. Acad. Nat. Sci. Phila., October, 1854, pp. 177-180.

1856. Kennerly, C. B. R. Pacific Railroad Reports, Vol. IV, I856. Route near the thirty-fifth parallel, explored by Lieutenant A. W. Whipple, topographical engineers, in 1853 and 1854 . > Part VI. Report on the Zoology of the Expedition. No. I. Field Notes and Explanations. By C. B. R. Kennerly, M. D., Physician and Naturalist to the Expedition. Pp. I-I7.

I858. Baird, S. F., Cassin, J., and Lawrence, G. N. Pacific Railroad Reports, Vol. IX, 1858. Fxplorations and Surveys for a Railroad Route from the Mississippi River to the Pacific Ocean. War Department. Birds: By Spencer F. Baird. Assistant Secretary Smithsonian Institution. With the cooperation of John Cassin and George N. Lawrence. Washington, D. C., 1858. Pp. i-lvi, I-I005.

1859. Baird, S. F. Report on the United States and Mexican Boundary Survey, made under the direction of the Secretary of the Interior, by William H. Emory, Major First Cavaliry and United States Commissioner. Vol. II. Washington, I859. > Part II, Zoology of the Boundary. $>$ Birds of the Boundary, by Spencer F. Baird. Pp. $\mathrm{I}-32,25$ pls.

1859. Heermann, A. L. Pacific Railroad Reports, Vol X, I859. > Route near the thirty-second parallel, from the Rio Grande to the Pimas Villages, etc. $>$ No. I. Report upon Birds collected on the Survey. By A. L. Heermann, M. D. Pp. 9-20 + I 1, 3 pls.

1859. Kennerly, C. B. R. Pacific Railroad Reports, Vo!. X, I359. > Part VI. Route near the thirty-fifth parallel, explored by Lieutenant A. W. Whipple, topographical engineers, in $\mathrm{I}_{53}$ and $\mathrm{I}_{54} .>$ no. 3 . Report on Birds collected on the Route. Pp. 19-35, I I pls.

I861. Baird, S. F. Report upon the Colorado River of the West, Explored in I 857 and 1858 by Lieutenant Joseph C. Ives, Corps of Topographical Engineers, Under the Direction of the Office of Explorations and Surveys, A. A. Humphreys, Captain 'Topographical Engineers, in Charge. By Order of the Secretary of War. Washington: Government Printing Office. I86I. $>$ V. Zoology. By Professor S. F. Baird. Pp. I-6. > List of Birds collected on the Colorado Expedition. Pp. 5-6. 
I86ı. Cooper, J. G. New California Animals. <Proc. Cal. Acad. Sci., II, I86I, pp. I I 8-1 23.

Includes original descriptions of Athcne whitneyi and Helminthophaga luciae, both from Fort Mohave, Arizona; also notes on sixteen species of birds from Fort Mohave and various localities in California.

1864-1866. Baird, S. F. Review of American Birds, in the Museum of the Smithsonian Institution. Part $\mathrm{I}=$ =Smithsonian Miscellaneous Collections. 181. Pp. i-vi, I-478, figs.

Contains the original description of Dendroica graciae, type from Fort Whipple, Arizona.

1865a. Coues, E. Ornithology of a Prairie-Journey, and Notes on the Birds of Arizona. < Ibis, 2d Series, I, 1865, pp. 157-165.

Running account of the birds seen on an overland journey from Washington, D. C., to Fort Whipple, Arizona.

1865b. Coues, E. [Notes on birds observed at Fort Whipple, Arizona.] < Ibis, 2d Series, I, 1865, pp. 535-538.

Extracts from a letter written from Fort Whipple.

1866a. Coues, E. List of the BIRDS of Fort Whipple, Arizona: with which are incorporated all other species ascertained to inhabit the Territory; with brief critical and field notes, descriptions of new species, etc. < Proc. Acad. Nat. Sci. Phila., XVIII, r866, pp. 39-100.

One of the most important publications relating to Arizona ornithology. Two hundred and forty-four species are listed, but this includes several now known not to occur in the state (Nauclerus furcatus, Ictinia mississippiensis, Certhiola flaveoia and others); while in some cases several names numbered separately are now known to refer to one species (Buteo swainsoni, B. oxypterus, and $B$. insignatus; Sphyrapicus williamsoni and $S$. thyroideus, etc.).

Contains the original descriptions of Vireofiumbeus ( $=$ Lanvereo solitarius plumbeus), and of Vireo vicinior, both from Fort Whipple.

I866b. Cones, E. Field Notes on Lophortyx gambeli. < Ibis, 2d Series, II, I866, pp. 46-55.

Habits, etc., as observed at Fort Whipple, Arizona.

I866c. Coues, E. From Arizona to the Pacific. <Ibis, 2d Series, II, I866, pp. 259-275.

Remarks on the species of birds seen on a journey from Fort Whipple, Arizona, to Fort Mohave, down the Colorado River to Fort Yuma and back to Fort Mohave, then across the desert to the coast of California at San Pedro. Extremely interesting notes on many (at the time) rare and little known birds-Crissal and Leconte thrashers, and many others.

1868. Coues, E. List of Birds collected in Southern Arizona by Dr. E. Palmer ; with remarks. < Proc. Acad. Nat. Sci. Phila., I868, pp. 8I-85.

Fifty-six species from the vicinity of Fort Grant, about sixty miles east of Tucson.

I869. Cooper, J. G. The Naturalist in California. < American Naturalist, III, I869, pp. 470-48I.

Observations made at Fort Mohave. 
1870. Cooper, J. G. Geological Survey of California. J. D. Whitney, State Geologist. Ornithology. Volume I. Land Birds. Edited by S. F. Baird, from the Manuscript and Notes of J. G. Cooper. Published by Authority of the Legislature. Pp. i-xi, I-592, many figs.

Many observations from the vicinity of Fort Mohave, Arizona.

I87 . Coues, E. The Long-crested Jay. < American Naturalist, V, i87 I, pp. 770-775, x fig.

Life history and habits as observed in northern Arizona.

1872a. Coues, E. A New Bird to the United States. \& American Naturalist. VI, I872, p. 370 .

Glaucidium ferrngineum ( $=$ Glancidium phalocnoides) taken near Tucson.

I872b. Coues, E. The Nest, Eggs, and Breeding Habits of Harporhynchus crissalis. < American Naturalist, VI, I872, pp. 370-37I.

Near Tucson.

1872c. Coues, E. Nest and Eggs of Helminthophaga Luciae. < American Naturalist, VI, I872, p. 493.

Nest and eggs, supposed to be of this species, from the vicinity of Tucson.

I872d. Cones, F. Occurrence of Conch's Flycatcher in the United States. $<$ American Naturalist, VI, I872, p. 493.

I872e. Coues, E. Observations on Picicorvus columbianus. < Ibis, I872, pp. 52-59.

I872f. Coues, E. Key to North American Birds, Containing a Concise Account of Every Species of Living and Fossil Bird at Present Known from the Continent North of the Mexican and Uniterl States Poundary. Illustrateci by 6 Steel Plates and Upwards of 250 Woodcuts. Salem: Naturalists' Agency. New York: Dodd and Mead. Boston: Estes and Lauriat. 1872. Pp. 4. I-36I, pls. I-VI, figs. I-238.

Contains original descriptions of Spizclla socialis var. arizonae, type from Fort Whipple. Arizona, and Harporhynchus curvirostris var. palmcri, type from Tucson, Arizona.

1872. Ridgway, R. On the Occurrence of Setophaga picta in Arizona. $<$ American Naturalist, VI, I 872 , p. 436 .

Near Tucson.

1873. Bendire, C. Nest, Eggs and Breeding Habits of the Vermilion Flycatcher (Pyrocephalus rubineus var. Mexicanus). < American Naturalist, VII, I873, pp. I 70-I7I.

As observed in southern Arizona.

1873. Brewer, T. M. Description of some Nests and Eggs of Arizona Birds. $<$ Proc. Boston Soc. Nat. Hist., XVI, I873, pp. I06- I I I.

From specimens collected by Lieut. C. Bendire near Tucson. 
1873. Coues, E. Some United States Birds, New to Science, and other things Ornithological. < American Naturalist, VII, I873, pp. 32I-33I, figs. 6570.

Original descriptions of Pcucaca carpalis and Harporhynchus bendirei, taken near Tucson.

I874. Coues, E. Birds of the Northwest: A Hand-book of the Ornithology of the Region Drained by the Missouri River and its Tributaries. =Miscellaneous Publications No. 3. U. S. Geol. Surv. of the Terr. Washington! I 874 , 8vo, pp. i-xi, I-79r.

1874. Henshaw, H. W. On a Hummingbird new to our Fauna, with certain other facts ornithological. < American Naturalist, VIII, I874, pp. 24I-243.

Eugencs fulgens taken at Camp Grant; Centrony.x Bairdi found abundantly in southern Arizona in the fall.

I874. Yarrow, H. C., and Henshiaw, H. W. Report upon Ornithological Specimens collected in the years I871, I872, and I873. < Geog. Surv. West Iooth Merid. by George M. Wheeler, I874, pp. I-I 48 .

I874. Ridgway, R. Two Rare Owls from Arizona. < American Naturalist, VII, I874, pp. 239-240.

Syminn occidentale ( = Strix occidentalis huachucae), the second known specimen, and Micrathene whitncyi ( = Micropallas whitneyi), the fourth known specimen.

1875a. Henshaw, H. W. Annual Report Geol. Surv. West Iooth Merid. by George M. Wheeler. -Appendix LL of the Annual Report Chief of Engineers for I875. 8vo., pp. i-iv, I-I96, pls. I-IX, maps, figs. > App. II, I2, pp. I39-166. > "Notes upon the ornithology of the regions traversed", pp. I49-I 50 ; "Annotated list of the birds of Arizona", pp. I53-166.

The list of the birds includes 294 species (erroneously numbered 291). Of these twelve are now considered not to occur in Arizona, leaving 282 species, as compared with 362 now accredited to the state.

1875b. Henshaw, H. W. Report upon the Ornithological Collections made in portions of Nevada, Utah, California, Colorado, New Mexico, and Arizona, during the years $187 \mathrm{r}, 1872,1873$, and $1874 .=$ Rep. Geog. Surv. West Iooth Merid. by George M. Wheeler, I875, vol. V, chapter III, pp. I20, I3I507, 977-989, pls. I-XV.

1877. Lawrence, G. N. Note on Doricha enicura (Vicill.). < Bull. Nuttall Orn. Club, II, I877, pp. I08-I09.

The specimen of hummingbird from Arizona recorded by Henshaw (1875a, p. 162) as Doricha cricura proves to be a female of Calothorax lucifer.

1877. Sharpe, R. B. Catalogue of the Passeriformes, or Perching Birts, in the Collection of the British Museun. Coliomorphae, Containing the Families Corvidae, Paradiseidae, Oriolidae, Dicruridae, and Prionopidae. =Cat. Birds, III, I877, pp. i-xiii, I-343, pls. I-XIV, many figs. in text.

I878. Brewer, 'J.' M. Notes on Junco caniceps and the Closely Allied Forms. $<$ Bull. Nuttall Orn. Club, III, I878, pp. 72-75.

Contains descriptions of the eggs of Itunco cinercus ( = Junco phaeonotus palliatus) and Junco dorsalis ( = Junco phaconotus dorsalis) from Arizona. 
1878. Coues, E. Birds of the Colorado Valley. A repository of Scientific and Popular Information concerning North American Ornithology. $=$ Miscellaneous Publications No. r I. U. S. Geol. Surv. of the Terr. Washington, 1878. 8 vo., pp. i-xvi, $1-807,66$ figs, in text.

1878. Stephens, F. Notes on a few Birds observed in New Mexico and Arizona in 1876. < Bull. Nuttall Orn. Club, III, 1878, pp. 92-94.

Observations on twenty species, generally without exact localities given. Mr. Stephens has informed me that the region covered was in the vicinity of Fort Bayard, New Mexico, and in southeastern Arizona (Fort Bowie, San Pedro River, and Tucson).

I879a. Brewer, T. M. The Cow-Blackbird of T'exas and Arizona (Molothrus obscurus). < Bull. Nuttall Orn. Club, IV, 1879, p. I23.

Regarding the size of the eggs.

I879b. Brewer, T. M. Notes on the Nests and Eggs of the Eight North American Species of Empidonaces. < Proc. U. S. Nation. Mus., II, 1879, pp. I-IO.

E. obscurus from Arizona, but the identification is questionable.

1881a. Brewster, W. Notes on Some Birds from Arizona and New Mexico, with a Description of a Supposed New Whip-poor-will. $<$ Bull. Nuttall Or11. Club, VI, I88I, pp. 65-73.

Seventeen species mentioned.

I88Ib. Brewster, W. On the Affinities of Certain Polioptilae, with a Description of a New Species. < Bull. Nuttall Orn. Club, VI, I88ı, pp. IOI-IO7.

Polioptila plumbca and $P$. melanura shown to be the same species, while the California bird is described under the name of Polioptila californica.

I88Ic. Brewster, W. Additions to the Avi-fauna of the United States. $<$ Bull. Nuttall Orn. Club, VI, I88I, p. 252.

Parus meridionalis ( = Penthestes sclateri) from the Chiricahua Mountains; Myiarchus cooperi ( = Myiarchus magister magister) from Fort Lowell; and Myiarchus lawrencei ( $=M$. l. olivascens) from the Santa Rita Mountains.

I88I. Bryant, W. E. Nest and Eggs of the Painted Flycatcher (Setophaga picta). < Bull. Nuttall Orn. Club, VI, I881, pp. I76-177.

Descriptions of nests and eggs taken by Mr. Herbert Brown in the Sarta Rita Mountains in June, 1880.

I88ıa. Coues, E. A Curious Colaptes. < Bull. Nuttall Orn. Club, VI, I88r, p. 183 .

I88 rb. Coues, E. Probable Occurrence of Sarcorhamphus papa in Arizona. $<$ Bull. Nuttall Orn. Club, VI, I88ı, p. 248.

A pair of birds supposed to be of this species, killed on the Verde River, but not preserved.

I881a. Holterhoff, E., Jr. A Collector's Notes on the Breeding of a Few Western Birds. < American Naturalist, XV, I88I, pp. 208-219.

Accounts of several species from Tucson, and westward to Los Angeles.

I88rb. Holterhoff, G. Verdin or Yellow Headed Titmouse. (Paroides flaviceps (Baird)). < Ornithologist and Oologist, VI, I88I, p. 27.

Breeding habits, as observed on the Colorado River, and at Tucson, Arizona. 
I88ı. Wood, W. California Pigny Owl (Glaucidium gnoma). <Ornithologist and Oologist. VT, 1881, pp. 33-35.47-48.

I882a. Bendire, C. E. American Long-eared Owl. <Ornithologist and Oologist, VI, I882, pp. 8I-82.

Mention of its occurrence in winter on Rillito Creek, near Tucson, Arizona.

I882b. Bendire, C. E. Mexican Goshawk. < Ornithologist and Oologist, VI, I882, pp. $87-88$.

An interesting account of the breeding habits of the Mexican Goshawk, Asturina nitida plagiata ( $=$ Asturina plagiata), as observed in southern Arizona (Santa Cruz River, San Pedro River, Rillito Creek).

I882c. Bendire, C. E. Whitney Owl. < Ornithologist and Oologist, VI, I882, pp. 94-96.

Observations on Micrathene ( $=$ Micropallas) whitneyi as observed on Rillito Creek, Arizona.

I882d. Bendire, C. E. The Spotted Owl. < Ornithologist and Oologist, VII, r882, p. 99.

Notes on two birds and an egg taken near Tucson in 1872.

1882e. Bendire, C. E. The Rufous-winged Sparrow. < Ornithologist and Oologist, VII, I882, pp. I2I-I 22.

An account of the habits of Peucaca ( = Aimophila) carpalis, as observed in the vicinity of Tucson and Camp Lowell, Arizona.

I882-83. Brewster. W. On a Collection of Birds Lately Made by Mr. F. Stephens in Arizona. < Bull. Nuttall Orn. Clıb, VII, I882, pp. 65-86, 135I47, I93-212; VIII, I883, pp. 2I-36.

I882. Brewster, W. Nest and Eggs of Setophaga picta-a Correction. < Bull. Nuttall Orn. Club, VII, r882, p. 249.

1882. Coures, E. Nesting of the White-bellied Wren (Thryothorns bervicki leucogaster). < Bull. Nuttall Oru. Club, VII, I882, pp. 52-53.

In northwestern Arizona.

1882. Evermann. B. W. Black-Crested Flycatcher. < Ornithologist and Oologist, VII, I882, pp. 169-170, I77-179.

Phainopepla nitcns as observed in southern California. Quotes from a letter of Capt. Bendire in regard to the species as observed in Arizona.

1882a. Ridgway, R. List of Additions to the Catalogue of North American Birds. <Bull. Nuttall Orn. Club, VII, I882, pp. 257-258.

r882b. Ridgway, R. Critical Remarks on the Tree-creepers (Certhia) of Europe and North America. < Proc. U. S. Nation. Mus., V, I882, pp. I I II I6.

Contains original description of Certhia familiaris montana, type from Camp Apache, Arizona.

1884. Adios. Some Arizona Quails. < Forest and Stream, XXII, 1884, p. 103.

1884. [Brown, H.] Ortyx virginianus in Arizona. $<$ Forest and Streaniı. XXII, I884, p. I04.

Announcement of the capture of " $a$ pair of genuine Bob White quail . . . . in the Barboquiviri range, about sixty miles southwest of Tuscon" ( $=$ Tucson). 
1884. Grinnel1, G. B. A Quail new to the United States Fauna. < Forest and Strean, XXII, I884, p. 243.

Imperfect specimens collected by Herbert Brown ("An almost complete skin of a, female bird, and portions of the wing, breast and tail of a male") identified by Ridgway as Ortyx graysoni.

1884a. Ridgway, R. Orty'x irirginian!s not in Arizona. < Forest and Stream, XXII, I 884 , P. I24.

Refers to the note published in the preceding number of the same paper (sec Brown, 1884, p. 104). The bird is presumed to be Cyrtonyt massena, or else "one of the Mexican species of Ortyy (perhaps O. Graysoni)."

I884h. Ridgway, R. Descriptions of Some New North American Birds. $<$ Proc. Biol. Soc. Wash.. II, I884, pp. \$9-95.

Includeś original descriptions of Myiarchus mexicanus magister and Myiarchus lawrencei olivascens.

I884c. Ridgway, R. Remarks on the Type Specimens of Muscicapa fulvifrons. Giraud, and Mitrephorus pallescens, Coutes. < Proc. Biol. Soc. Wash., II, I 884, pр. Iо8-і 1о.

I 885a. Brewster, W. Preliminary Notes on Sonse Birds Obtained in Arizona by Mr. F. Stephens in I884. < Auk, II, I885, pp. 84-85.

I885b. Brewster, W. Additional Notes on Some Birds Collected in Arizona and the Adjoining Province of Sonora, Mexico, by Mr. F. Stephens in 1884: with a Description of a New Species of Ortyx. < Auk, II, 1885, pp. I96200.

Notes on nineteen species; contains the original description of Colinus ridgwayi.

1885a. Brown, H. Peculiar Ėggs of Scops Tricliopsis. < Ornithologist and Oologist, X, 1885, p. 96.

Description of a set of blotched eggs of Scops trichopsis ( = Otus asio gilmani); considered as possibly the result of lybridism between that species and Falco sparverius!

I885b. Brown, H. Arizona Bird Notes. < Forest and Stream, XXIV, I885, p. 367 .

1885c. Brown, H. Arizona Quail Notes. < Forest and Stream, XXV, 1885. p. 445 .

Deals chietly with Colinus ridgwayi, now considered as the bird previously identi fied by Ridgway as Ortyx graysoni. Detailed account of habits, distribution, etc.

1885a. Ridgway, R. Icterus cucullatus, Swainson, and its Geographical Variations. < Proc. U. S. Nation. Mus., VIII, I885, pp. I8-19.

Contains the original description of Icterus cucullatus nelsoni, type locality Tucson, Arizona.

I885b. Ridgway, R. Some Emended Names of North American Birds. < Proc. U. S. Nation. Mus., VIII, I885, pp. 354-356.

1885c. Ridgway, R. Description of a New Cardinal Grosbeak from Arizona. $<$ Auk, II. I885, pp: 343-345.

Cardinalis inrdinalis superbus, new subspecies, type locality near Fort Lowell. 
I885d. Ridgway, R. On Junco cinereus (Swains.) and its Geographical Races. $<$ Auk, II, I 885, pp. 363-364.

I885a. Scott, W. E. D. On the Breeding Habits of Some Arizona Birds. First Paper. Ictcrus parisorum. < Auk, II, I885, pp. I-7. Second Paper. Icterus cucullatus. Pp. I59-165. Third Paper. Phainopepla nitens. Pp. 242246. Fourth Paper. Vireo vicinior. Pp. 321-326.

As observed in the vicinity of Tucson and in the Santa Catalina Mountains,

I885b. Scott, W. E. D. Winter Mountain Notes from Southern Arizona. $<$ Auk, II, I885, pp. I72-I 74 .

Running account of the birds seen at the summit of the Santa Catalina Mountains, November 26 to 29, 1884.

I885c. Scott. W. E. D. Early Spring Notes from the Mountains of Southern Arizona. < Auk, II, I885, pp. 348-356.

Birds seen in the Santa Catalina Mountains, April 19 to 24, 1885.

I885d. Scott, W. E. D. A Mule Bird. < Forest and Stream, XXIII, r885, p. 484 .

Hybrid between Colaptes cafer collaris and Colaptes chrysoides mearnsi. (Originally published in the "Arizona Daily Star", Tucson, Dec. 16, 1884.)

I885. Sharpe, R. B. Catalogue of the Passeriformes, or Perching Birds, in the Collection of the British Museum. Fringilliformes: Part I. Containing the Families Dicaeidae, Hirundiniclae, Ampelidae, Mniotiltidae, and Motacillidae. $=$ Cat. Birds, X, I885, pp. i-xiii, I-682, pls. I-XII, figs.

1885. Stephens, F. Notes on an Ornithological Trip in Arizona and Sonora. $<$ Auk, II, I885, pp. 225-23I.

Running account of birds seen in the valley of the Santa Cruz River, from Tucson southward, in August, 1884.

I886a. Allen, J. A. The Masked Bob-white (Colinus ridga'ayi) of Arizona, and its Allies. < Bull. Amer. Mus. Nat. Hist., I, I886, pp. 273-290, I pl.

Complete history of the species up to date. Habits, distribution, bibliography, etc.

I886b. Allen, J. A. The Masked Bob-white (Colinus ridgwayi) in Arizona. $<$ Auk, III, I886, pp. 275-276.

Thirteen specimens from Barboquiviri Mountain.

I886c. Allen, J. A. The Type Specimen of Colinus ridgwayi. < Auk, III, ı886. p. 483 .

A brief note stating that the type is in the collection of G. F. Morcom.

1886. Hargitt, E. Notes on Woodpeckers. On a new Species from Arizona. $<$ Ibis, I886, pp. I I2-I I5.

Contains the original description of Picus arizonae ( $=$ Dryobates arizonae $)$, type fron: the Santa Rita Mountains.

I886a. Mearns, E. A. Some Birds of Arizona. < Auk, III, ı886, pp. 60-73.

Buteo abbreviatus and Urubitinga onthracina breeding in central Arizona. Descriptions of adults and young, habits, etc. 
1886b. Mearns, E. A: Some Birds of Arizona. < Auk, III, ı886, pp. 289-307. Crissal and Leconte thrashers, as observed in Arizona.

1886. Parker, H. G. Nest and eggs of the Plumbeous Gnatcatcher. < Ornithologist and Oologist, XI, April, I886, p. 54.

Polioptila plumbea breeding in Pinal County, Arizona.

1886. Ridgway, R. Arizona Quail. < Forest and Stream, XXV, I886, p. 484. $\mathrm{Mr}$. Ridgway does not think "that Mr. Brown has demonstrated the specific identity of Colinus ridgwayi Brewst. and the pair of birds I identified as Ortyx (now Colinus) graysoni Lawr."

1886. Sclater, P. L. Catalogue of the Passeriformes, or Perching Birds, in the Collection of the British Museum. Fringilliformes: Part II. Containing the Families Coerebidae, Tanagridae, and Icteridae. = Cat. Birds, XI, I886, Pp. i-xvii, I-43I, pls. I-XVIII, many figs.

I886. Scott, W. E. D. On the Breeding Habits of Some Arizona Birds. < Auk, III, I886, pp. 8I-86.

Aphelocoma sieberii arizonae, Pencaea ruficeps boucardi ( = Aimophila ruficeps scotti), and Lophophanes zuollweberi $(=$ Baeolophus wollweberi) in the Santa Catalina Mountains.

1886-I888. Scott, W. E. D. On the Avi-Fauna of Pinal County, with Remarks on Some Birds of Pima and Gila Counties, Arizona. With annotations by J. A. Allen. < Auk, III, I886, pp. 249-258, 383-389, 42I-432; IV, I887, pp. I6-24, I96-205; V, I 888, pp. 29-36, г 59-168.

Two hundred and forty-six species listed, with extensive annotations.

I887. Allen, J. A. A Further Note on Colinus ridgwayi. < Auk, IV, I887. pp. $74-75$.

1887. Bendire, C. E. Notes on a Collection of Birds' Nests and Eggs from Southern Arizona Territory. < Proc. U. S. Nation. Mus., X, I887, pp.

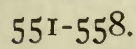

I887a. Brewster, W. Three New Forms of North American Birds. $<$ Auk. IV, I887, pp. I 45-I 49 .

Contains the original description of Phalacnoptilus muttalli nitidus; Arizona examples mentioned.

1887b. Brewster. W. Further Notes on the Masked Bob-white (Colinus ridgzavi). < Auk, IV, I887, pp. I59-160.

Found commonly in northern Sonora, Mexico. Habits, etc.

1887. Brown, H. Arizona Bird Notes. < Forest and Stream, XXVII, I887, p. 464 .

1887. Morcom, G. F. Notes on the Birds of Southern California and Southwestern Arizona. < Ridgway Orn. Club, Bull. No. 2, I887, pp. 36-57.

The Arizona observations are of a few species from the vicinity of Yuma.

I887. Parker, H. G. Notes on the Eggs of the Thrushes and Thrashers. $<$ Ornithologist and Oologist, XII, I887, pp. 69-73.

Includes descriptions of some Arizona specimens. 
1887a. Ridgway, R. The Coppery-tailed Trogon (Trogon ambiguus) breeding in Southern Arizona. < Auk, IV, I887, pp. I6I-I62.

In the Huachuca Mountains.

I887b. Ridgway, R. Trogon ambigutus breeding in Arizona. < Proc. U. S. Nation. Mus., X, I887, p. 147 .

In the Huachuca Mountains.

I887c. Ridgway, R. Description of a new Psaltriparus from Southern Arizona.

< Proc. U. S. Nation. Mus., X, I887, p. 697.

Psaltriparus santaritac, type locality Santa Rita Mountains $(=$ Psaltriparus plumbeus in juvenal plumage).

I888. Bendire, C. E. Notes on the Habits, Nests and Eggs of the Genus Glancidium Boie. < Auk, V, I888, pp. 366-372.

Including an account of $G$. phalocnoides, as observed in southern Arizona.

I888a. Brown, H. Ionornis martinica in Arizona. < Auk, V, ı888, p. Iog.

One specimen, Tucson, October 20, 1887.

I888b. Brown, H. On the Nesting of Palmer's Thrasher. < Auk, V, I888, pp. I I6-I I8.

In southern Arizona:

I888a. Price, W. W. Nesting of the Red-faced Warbler (Cardellina rubrifrons) in the Huachuca Mountains, Southern Arizond. < Auk, V, r888, pp. 385386.

1888b. Price, W. W. Xantus's Becard (Platypsaris albiventris) in the Huachuca Mountains, Southern Arizona. < Auk. V, I888, p. 425.

One specimen, an adult male, June 20, 1888.

I888. Sharpe, R. B. Catalogue of the Passeriformes, or Perching Birds, in the Collection of the British Museum. Fringilliformes: Part III. Tontaining the Family Fringillidae. = Cat. Birds XII, I888, pp. i-xv, I-87I, pls. IXVI, many figs.

I888. Sennett, G. B. Notes on the Peucaca ruficeps Group. with Description of a New Subspecies. < Auk, V, r888, pp. 40-42.

Peucaea ruficcps scottii, new subspecies, described from Pinal County, Arizona.

I888a. Swinburne, J. Breeding of the Evening Grosbeak (Coccothraustes vespertina) in the White Mountains of Arizona. < Auk, V, I888, pp. II3-II4.

1888b. Swinburne, J. Occurrence of the Chestnut-collared Longspur (Calcarius ornatus) and also of Maccown's Longspur (Rhyncophones maccozenii) in Apache Co., Arizona. < Auk, V, I888, pp. 32I-322.

1889. Allen, J. A. Note on the First Plumage of Colinus ridgwayi. < Auk, VI, I889, p. I89.

Description of a young male taken at Tubal (70 miles south of Tucson), October $10,1888$.

1889. Cones, E. [A New Generic Name for the Elf Owl.] < Auk, VI, I889, p. 71 . 
I 88ga. N[orris]., J. P. A Series of Eggs of Bendire's Thrasher. < Ornithologist and Oologist, XIV, I889. pp. 23-25.

Detailed descriptions of twenty-nine nests and sets of eggs, all from southern Arizona (Pima and Pinal counties).

I 889b. N[orris]., J. P. Eggs of the Mexican Ground Dove. < Ornithologist and Oologist, XIV, I889, pp. 59-60.

Taken near Tucson.

I8go. Bendire, C. E. Notes on Pipilo fuscus mesoleucus and Pipilo aberti, their Habits, Nests and Eggs. < Auk, VII, I890, pp. 22-29.

I800. Brewster, W. A New Subspecies of the Solitary Sandpiper. $<$ Auk, VII, I 890, pp. 377-379.

I89o. Dwight, J., Jr. The Horned Larks of North America. < Auk, VII, 1890, pp. 138-158, I pl.

Contains the original description of Otocoris alpestris adusta, type locality Fort Huachuca, Arizona.

I890. Hargitt, E. Catalogue of the Picariae in the Collection of the British Museum. Scansores, containing the Family Picidae. = Cat. Birds, XVIII, I890, pp. i-xv, I-597, pls. I-XV, many figs.

I890a. Mearns, E. A. Observations on the Avifauna of Portions of Arizona. $<$ Auk, VII, I8go, pp. 45-55, 25I-264.

Annotated list of species from the high mountains of central Arizona.

I 89ob. Mearns, E. A. Descriptions of a New Species and Three New Subspecies of Birds from Arizona. < Auk, VII, I89o, pp. 243-25I.

Junco ridgwayi, type locality Fort Whipple, Spinus tristis pallidus, Fort Verde, and Mclanerpes formicivorus aculeatus, Squaw Peak, central Arizona.

I890. Merriam, C. H. Annotated List of Birds of the San Francisco Mountain Plateau and the Desert of the Little Colorado River, Arizona. < North American Fauna No. 3, I890, pp. 87-101.

Birds observed at the Grand Canyon of the Colorado arc listed on pp. 38-41.

I890. N[orris].,J. P. A Series of Eggs of Palmer's Thrasher. < Ornithologist and Oologist, XV, I890, pp. I 54-1 56.

Descriptions of twenty-one nests and sets of eggs, all from the vicinity of Tucson, Arizona.

I8goa. Poling, O. C. The Presence of McCown's and the Chestnut-collared Longspur in Southern Arizona. Near the Mexican Border. <Ornithologist and Oologist, XV, I890, p. 7I.

At Fort Huachuca during February and March.

I8gob. Poling, O. C. Nesting of the Arizona Jay. < Ornithologist and Oologist, XV, I890, p. 138 .

In the Huachuca Mountains, Arizona.

I89oc. Poling, O. C. On the Nesting Habits and Eggs of the Vermilion Flycatcher. < Ornithologist and Oologist, XV, I890, p. I40.

As observed at Fort Huachuca, Arizona. 
I89od. Poling, O. C. Notes on Eugenes fulgens. < Auk, VII, I890, pp. 402403.

As observed in the Huachuca Mountains.

1890. Sharpe, R. B. Catalogue of the Passeriformes, or Perching Birds, in the Collection of the British Museum. Sturniformes, Containing the Families Artamidae, Sturnidae, Ploceidae, Alaudidae. Also the Families Atrichiidae and Menuridae. $=$ Cat. Bircls. XIII, I890, pp. i-xvi, I-70I, pls. I-XV, many figs.

I890. White, H. G. Geographical Variation of Eggs. < Ornithologist and Oologist, XV, I89o, pp. I-4.

Descriptions of several sets of eggs from points in Arizona.

I891. Anthony, A. W. Notes on the Cactus Wren. < Zoe, II, I891, pp. I33I34.

Comparison of nesting habits in southern California and in New Mexico and Arizona.

I89I. Ladd, S. B. Description of the Nests and Eggs of Dendroica graciae and Contopus pertina. $<$ Auk, VIII, I89I, pp. 3I4-3I5.

From Yavapai County, Arizona.

I89i. Poling, O. C. Groove-billed Ani (Crotophaga sulcirostris) in Arizona. $<$ Auk, VIII, r891, pp. 313-3I4.

A specimen taken in the Huachuca Mountains in May, 1888.

189I. Sclater, P. L., and Shelley, G: E. Catalogue of the Picariae in the Collection of the British Museum. Scansores and Coccyges, Containing the Families Rhamphastidae, Galbulidae, and Bucconidae, by P. L. Sclater, and the Families Indicatoridae, Capitonidae, Cr:culidae, and Musophagidae, by C. E. Shelley. = Cat. Birds. XIX, I891, pp. i-xii, I-484, pls. I-XIII.

I892. Bendire, C. Life Histories of North American Birds with special reference to Their Breeding Flabits and Eggs, with Twelve Lithographic Platcs. = Special Bulletin No. I, U. S. Nation. Mus. Washington: IS92. Pp. i-viii. I -446 .

1892. Brown, H. The Habits and Nesting of Palner's 'Thrasher. (Harporhynchus curvirostris palmeri.) < Zoe, III, I892, pp. 243-248.

I892a. Coues, E. Wintering of the Canvasback in Arizona. <Auk, 1X, I892, p. Ig8.

On the Verde River near Fort Whipple.

1892b. Coues, E. Nesting of the Golden Eagle in Arizona. < Auk, IX, I892, p. 201.

Near Prescott.

1892. Fisher, A. K. Myiarchus nuttingi in Arizona. < Auk, IX, I892, p. 394. The birds here recorded as Myiarchus nuttingi eventually proved to be females of M. cineraszens (see Nelson, 1904).

1892. Hartert, E. [See Salvin and Hartert.] 
1892. Mearns, E. A. A Study of the Sparrow Hawks (Subgenus Tinnunculus) of America, with Especial Reference to the Continental Species (Falco sparverius Linn.) < Auk, IX, 1892, pp. 252-270.

Contains the original description of Falco sparverius deserticolus, type locality Fort Verde, Arizona.

I 892. Pember, F. T. Collecting in the Gila Valley. < Wilson Quarterly, IV, pp. I-9, 49-54.

A narrative account of the birds in the vicinity of Gila Bend, of considerable interest, though unfortunately none but the English names of birds are used. Of especial note is the description of the nesting of the Mexican Goshawk, this being the westernmost record of the species in Arizona.

1892. Rhoads, S. N. The Birds of Southeastern Texas and Southern Arizona Observed during May, June, and July, ı89ı. < Proc. Acad. Nat. Sci. Phila., 1892, pp. 99-1 26.

Arizona localities visited were Tucson, Santa Catalina Mountains, "Santa Clara River" ( = Santa Cruz River ?), and Oracle.

1892. Salvin, O., and Hartert, E. Catalogue of the Picariae in the Collection of the British Museum. Upupae and Trochili by Osbert Salvin. Coraciae, of the Families Cypselidae, Caprimulgidae, Podargidae, and Steatornithidae. by Ernst Hartert. = Cat. Birds, XVI, I892, pp. i-xvi, I-703, pls. I-XIV.

1893. Allen, J. A. List of Mammals and Birds collected in Northeastern Sonora and Northwestern Chihuahua, Mexico, on the Lumholtz Archaeological Expedition, I890-92. < Bull. Amer. Mus. Nat. Hist., V, I893, pp. 27-42.

Some specimens collected near Bisbee, Arizona.

I893a. Fisher, A. K. The Hawks and Owls of the United States in their Relation to Agriculture. = U. S. Dept. Agric., Div. Orn. and Mam., Bull. No. 3, pp. I-2IO, pls. I-26.

1893b. Fisher, A. K. Report on the Ornithology of the Death Valley Expedition of $189 \mathrm{I}$, comprising Notes on the Birds Observed in Southern California, Southern Nevada, and Parts of Arizona and Utah. < North American Fauna No. 7, I893, pp. 7-1 58.

Contains notes on species seen in extreme northwestern Arizona.

189.3. Hasbrouck, E. M. The Geographical Distribution of the Genus Megascops in North America. < Auk, X, r89r, pp. 250-264, pl. VI, a, b (distribution maps).

I893. Ogilvie-Grant, W. R. Catalogue of the Game Birds (Pterocletes, Gallinae, Opisthocomi. Hemipodii) in the Collection of the British Museum. $=$ Cat. Birds, XXII, r893, pp. i-xvi, I-585, pls. I-VIII.

I893. Salvadori, T. Catalogue of the Columbae, or Pigeons, in the Collection of the British Museum. = Cat. Birds, XXI, I893, pp. I-xvii, I-676, pls, I-XV.

1894. Coale, H. K. Ornithological Notes on a Flying Trip Through Kansas, New Mexico, Arizona and Texas. < Auk, XI, 1894, pp. 215-222.

Includes brief notes on the birds seen at Forts Verde, Whipple, Mohave, Lowell, Huachuca, Grant, and Thomas, and at San Carlos. 
I894. Fisher, A. K. The Capture of Basilinna leucotis in Southern Arizona. $<$ Auk, XI, I894, pp. 325-326.

One specimen taken in the Chiricahua Mountains, June 9, 1894. The first record for the United States.

I894. Ridgway, R. On Geographical Variation in Sialia mexicana Swainson. $<$ Auk, XI, I894, pp. I45-I60.

Contains the original description of Sialin mexicana bairdi, type locality "Camp 110, New Mexico" ( $=$ Cactus Pass, near Kingman, Arizona).

I895. Bendire, C. Life Histories of North American Birds, from the Parrots to the Grackles, with special reference to Their Breeding Habits and Eggs. With Seven Lithographic Plates. Special Bulletin No. 3, U. S. Nat. Mus. Washington: I895, pp. i-ix, I-5I8.

I895. Mearns, E. A. Description of a New Heron (Ardea virescens anthonyi) from the Arid Region of the Interior of North America. < A tı, XII, I895. pp. 257-259.

I895. Merriam, C. H. The Leconte Thrasher, Harporhynchus lecontei. < Auk, XII, I895, pp. 54-60, I pl., I fig.

Distribution, breeding habits, etc.

I895. Price, W. W. The Nest and Eggs of the Olive Warbler. (Dendroica olivacea). < Auk, XII, I895, pp. I7-I9.

General account of the species as observed in Arizona. Breeding habits, nest and eggs, distribution, etc.

1895. Ridgway, R. On the Correct Subspecific Names of the Texan and Mexican Screech Owls. < Auk, XII, I895, pp. 389-390.

I896. Saunders, H., and Salvin, O. Catalogue of the Gaviae and Tubinares in the Collection of the British Museum. Gaviae (Terns, Gulls, and Skuas) by Howard Saunders. Tubinares (Petrels and Albatrosses) by Osbert Salvin. $=$ Cat. Birds, XXV, I896, pp. i-xv, I-475, pls. I-VIII, figs.

1896. Sharpe, R. B. Catalogue of the Limicolae in the Collection of the British Museum. = Cat. Birds, XXIV, I896, pp. i-xii, I-794, pls. I-VII, many figs.

I897a. Breninger, G. F. A roosting method of the Inca dove. < Osprey, I, I897, p. II I.

At Phoenix, Arizona.

I897b. Breninger, G. F. An unusual nesting site. < Osprey, I, I897, p I 22.

Six eggs of the Gambel quail "deposited in a hollow of a Mesquite tree, several feet from the ground, and probably eighteen inches from the opening of the cavity".

1897c. Breninger, G. F. An albino green-tailed towhee. < Osprey, I, I897, p. 137.

At Phoenix, Arizona.

I897d. Breninger, G. F. Coues Flycatcher. < Osprey, II, I897. p. I2.

In the Huachuca Mountains, Arizona. 
I897e. Breninger, G. F. Nocturnal Flights of the Turkey Vulture. < Osprey, II, 1897, pp. 54-55.

A roost at San Andreas Canyon, thirty miles southwest of Tucson.

I898a. Breninger, G. F. Barn Swallows in southern Arizona < Osprey, II, I 898 , p. I I 7 .

Breeding at Elgin, Santa Cruz County, Arizona.

I898b. Breninger, G. F. The ferruginous pygmy owl. < Osprey, II, I898, p. I 28, I fig.

As observed on the Gila and Salt rivers.

I 898c. Breninger, G. F. Hybridization of Flickers. < Osprey, III, I898, p. I3.

Supposed hybrids between Colaptes chrysoides and $C$. auratus and between $C$. chryioides and $C$. cafer, from southern Arizona.

I898. Brewster, W. Occurrence of the Spotted Screech Owl (Megascops aspersus) in Arizona. < Auk, XV, I898, p. 186.

Two specimens of Megascops aspersus ( $=$ Otus trichopsis [Wagler]), taken in the Huachuca Mountains, Arizona, on August 10, 1891, and June 20, 1895, respectively.

1898. Oberholser, H. C. A Revision of the Wrens of the Genus Thryomanes Sclater. < Proc. U. S. Nation. Mus., XXI, I898, pp. 42I-450.

I898a. Ridgway, R. Descriptions of Supposed New Genera, Species, and Subspecies of American Birds. I. Fringillidae. < Auk, XV, I898, pp. 223-230.

Contains the description of Amplispiza bilineuta deserticola, type locality Tucson, Arizona.

I 898b. Ridgway, R. Description of a New Species of Hummingbird from

Arizona. <Auk, XV, I898, pp. 325-326.

Atthis morcomi, type locality Huachnca Nountains, Arizona:

I898. Willard, F. C. Quails going to roost. < Osprey, II, I898, p. I34.

Callipepli squamata, as observed near Tombstone.

ז899a. Preninger. G. F. Gambel's Quail. < Osprey, III, I899, pp. 84, 85. 2 figs.

As observed in southern Arizona.

I899b. Breninger, G. F. A Nest of the Blue-throated Hummingbird. <Osprey, III, I899, p. 86. 1897.

A nest with eggs of Coeligena clcmenciue taken in the Huachuca Mountains in June,

1899c. Breninger, G. F. White-tailed Hawk in Arizona. < Auk, XVI, i899. p. $35^{2}$.

Specimens of Buteo albicaudatus sennetti taken between Florence and Red Rock, where breeding, and at Phoenix.

1899a. Brown, H. The Scarlet Ibis (Guara rubra) in Arizona. < Auk, XVI, I 899, p. 270.

A flock, supposed to be of this species, seen near Fort Lowell, September 17, 1890.

ı 899b. Brown, H. The California Vulture in Arizona. < Auk, XVI, I899, p. 272. 
1899. Henninger, W. F. Note of the Spotted Screech Owl (Megascops trichopsis). < Osprey, IV, I899, p. 29.

An adult male taken in the Huachuca Mountains, May 27, 1899.

I899a. Howard, O. W. Summer Resident Warblers of Arizona. <Bull. Cooper Orn. Club, I, I899, pp. 37-40, 2 figs.; pp. 63-65.

Field observations on nine species of warblers.

I899b. Howard, O. W. Some of the Summer Flycatchers of Arizona. < Bull. Cooper Orn. Club, I, I899, pp. 103-107, 2 figs.

Field observations on the Sulphur-bellied, Olivaceous, and Buff-breasted flycatchers.

I899a. Lusk, R. D. New Nesting Location of Rivoli Hummer (Eugenes fulgens). < Osprey, III, I899, pp. I40-I4I.

In the Huachuca Mcuntains, Arizona.

I899b. Lusk, R. D. Nesting of the Sulphur-bellied Flycatcher. < Bull. Cooper Orn. Club, I, I899, pp. I I 2-I I3.

In "southern Arizona." Locality not given.

1899. Price, W. W. Some Winter Birds of the Lower Colorado Valley. $<$ Bull. Cooper Orn. Club, r, r899, pp. 89-93.

Ninety-one species observed between Yuma and the mouth of the Colorado River.

I899. Willard, F. C. Notes on Eugenes fulgens. < Osprey, III, I899, pp. 6566, I pl.

Nesting in the Huachuca Mountains.

1900. Dwight, J., Jr. The Moult of the North American Shore Birds (Limicolae). <Auk, XVII, I900, pp. 368-385.

Makes mention of specimens of several species secured in Arizona.

1900a. Howard, O. W. Nesting of the Mexican Wild Turkey in the Huachuca Mts., Ariz. (Meleagris gallopavo). < Condor, II, I900, pp. 55-57, 2 figs.

rgoob. Howard, O. W. Nesting of the Rivoli Hummingbird in Southern Arizona. < Condor, II, I900, pp. IOI-IO2, 2 figs.

In the Huachua Mountains.

1900. Jones, L., and Dawson, W. L. A Summer Reconnoissance in the West. = Wilson Bulletin, No. 33, 1900, pp. I-39.

Contains lists of birds seen on San lirancisco Mountain and at Mellen, on the Colorado River.

1900. Lusk, R. D. Parrots in the United States. < Condor, II, I900, p. r29.

Rhynchopsitta pachyrhyncha in the Chiricahua Mountains, Arizona.

I900a. Nelson, E. W. Description of a New Subspecies of Melcagris galloparo and Proposed Changes in the Nomenclature of Certain North American Birds. < Auk, XVII, 1900, pp. I20-126.

Meleagris gallopavo merriami, type locality 47 miles southwest of Winslow, Arizona.

1900b. Nelson, E. W. Descriptions of Thirty New North American Birds, in the Biological Survey Collection. < Auk, XVII, I900, pp. 253-270.

Contains the original description of Cyrtonyix montezumae mearnsi, type locality Fort Huachuca, Arizona. 
Ig00. Smith, P. W. Nesting of Stephens Whippoorwill. < Osprey, IV, I900, p. 89.

In the Huachuca Mountains, Arizona.

I90Ia. Breninger, G. F. A List of Birds Observed on the Pima Indian Reservation, Arizona. < Condor, III, I9or, pp. 44-46.

Eighty-six species seen during four days in September.

Igorb. Breninger, G. F. The Painted Redstart. < Condor, III, I9oI, pp. I47I 48 , I fig.

Field observations in the Huachuca and Santa Rita mountains.

190ra. Brown, H. Bendire's Thrasher. < Auk, XVIII, I90I, pp. 225-23I. Nest, eggs and habits, as observed in southern Arizona.

19orb. Brown, H. A Band-tailed Hawk's Nest-An Arizona Incident of Biographical Interest. < Auk, XVIII, 190I, pp. 392-393.

ıgor. Loomis, L. M. An Addition to the A. O. U. Check-List. < Auk, XVIII, Ig0I, pp. IO9-IIO.

Dendroica nigrifrons taken in the Huachuca and Chiricahua mountains, Arizona. 190I. Lusk, R. D. In the Summer Home of the Buff-breasted Flycatcher. $<$ Condor, III, I90I, pp. 38-4I, I fig.

Field observations in the Santa Rita and Chiricahua mountains.

190r. Mearns, E. A. An Addition to the avifauna of the United States. $<$ Proc. Biol. Soc. Wash., XIV, I90I, pp. I77-1 78.

Petrochclidon mclanogaster in the valleys of the San Bernardino and Santa Cruz rivers, southern Arizona.

Igor. Ridgway, R. The Birds of North and Middle America. = U. S. Nation. Mus. Bull., no. 50, part I, pp. i-xxx, I-715, pls. i-xx.

1902. Brewster, W. Birds of the Cape Region of Lower California. = Bull. Mus. Comp. Zool., XLI, I902, pp. I-24I, map.

Contains many references to Arizona birds.

1902. Brown, H. Unusual Abundance of Lewis's Woodpecker near Tucson, Arizona, in I884. < A Alk, XIX, I902, pp. 80-83.

1902. Goldman, E. A. In Search of a New Turkey in Arizona. < Auk, XIX, 1902, pp. I $21-127$.

Meleagris gallopavo merriami, as observed in the Mogollon Mountains

1902. Howard, O. W. Nesting of the Prairie Falcon. < Condor, IV, I902, pp. 57-59.

In the Huachuca Mountairs, Arizona.

1902a. Mearns, E. A. Description of a Hybrid between the Barn and Cliff Swallows. < Auk, XIX, I902, pp. 73-74.

Igo2b. Mearns, E. A. The Cactus Wrens of the United States. < Auk, XIX, I902, pp. I4I-I 45 . ing, Arizona.

Helcodytes brunneicapillus anthonyi, new subspecies, described from Adonde Sid- 
Igo2c. Mearns, E. A. Descriptions of Three New Birds from the Southern United States. < Proc. U. S. Nation. Mus., XXIV, I902, pp. 9I5-926.

Contains the original description of Sitta carolinensis nelsoni, type locality Huachuca Mountains, Arizona.

1902. Oberholser, H. C. A Review of the Larks of the Genus Otocoris. <Proc. U. S. Nation. Mus., I902, XXIV, pp. 80I-884, 7 pls.

Contains the original description of otucoris alpestris leucansiptila, type locality Yuma, Arizona.

I902. Ridgway, R. The Birds of North and Middle America. = U. S. Nation. Mus. Bull., no. 50, part 2, pp. i-xx, I-834, pls. i-xxii.

1903. Bailey, V. The White-necked Raven. < Condor, V. I903. pp. 87-89, 2 figs.

Field observations on breedirg habits, etc.

I903. Breninger, G. F. Nest and Ëggs of Coeligena clemenciac. < Auk, XX. I903, p. 435 .

In the Huachuca Mountains, Arizona.

I903. Brown, H. Arizona Bird Notes. < Auk, XX, I903, pp. 43-50.

Running account of several species from the vicinity of Yuma.

1903. Fisher, A. K. A Partial List of the Birls of Keam Canyon, Arizona. $<$ Condor, V, 1903, pp. 34-36.

Thirty-nine species observed in July, 1894.

1903. Fowler, F. H. Stray Notes from Southern Arizona. < Condor, V, I903. pp. 68-71, 106-107.

Habits and manner of occurrence in Arizona of the following species of birds: Cyrtonyx montezumac mearnsi, Columba fasciata, Trogon ambiguus, Urubiting anthracina, Micropallas zuhitneyi, Dryobates arizonae, Eugencs fulgcns, Basillina leucotis.

I903. Lusk, R. D. Wasted Talent. < Condor, V, I903, p. I35.

Descriptive of a nest of Myiarchus l. olivascens.

1903a. Oberholser, H. C. A Review of the Genus Catherpcs. < Auk, XX, I903, pp. 196-198.

Igozb. Oberholser, H. C. A Synopsis of the Genus Psaltriparus. < Auk, XX, Igo3, pp. I98-20I.

Psaltriparus santaritae considered to be the immature of $P$. melanotis lloydi.

1903c. Oberholser, H. C. The North American Forms of Astragalinus psaltria (Say). < Proc. Biol. Soc. Wash., XVI, I903, pp. II3-II6.

I903. Osgood, W. H. A List of Birds Observed in Cochise County, Arizona. $<$ Condor, V, I903, pp. I28-I3I, I49-I5I.

An annotated list of one hundred and twenty-three species observed from November 1,1894 , to June 1,1895 . 
1903. Stephens, F. Bird Notes from Eastern California and Western Arizona. $<$ Condor, V, I903, pp. 75-78, I00-105.

An annotated list of the species of birds observed in portions of the Colorado and Mohave Deserts, California, and from the Colorado River, at the Needles, to the Hualpai Mountains, in Arizona.

I904. Brown, H. Masked Bob-white (Colinus ridgruayi). < Auk, XXI, I904, pp. 209-2I3.

History of the species up to date, with field observations, on habits, range, etc. Believed to be extinct in Arizona.

Ig04. Cooke, W. W. Distribution and Migration of North American Warblers. $=$ U. S. Dept. Agric., Div. Biol, Surv., Bull. no. 18, pp. I-I42.

Contains the only Arizona record of the Prothonotary Warbler.

I904. Fisher, A. K. [Review of Swarth's Birds of the Huachuca Mountains, Arizona.] < Condor, VI, I904, pp. 80-8I.

Twelve species are added to the list contained in the paper reviewed, one of them, Dendroica virens, being here recorded from Arizona for the first time.

I904. Howard, O. W. The Coues Flycatcher as a Guardian of the Peace. $<$ Condor, VI, I904, pp. 79-80.

An account of some of the breeding habits of the species, as observed in the Huachuca Mountains, Arizona.

1904. Nelson, E. W. A Revision of the North American Mainland Species of Myiarchus. < Proc. Biol. Soc. Wash., XVII, 1904, pp. 2I-50.

Supposed Arizona specimens of $M$. muttingi prove to be females of $M$. cinerascens.

Igo4a. Oberholser, H. C. A Revision of the American Great Horned Owls. < Proc. U. S. Nation. Mus., XXVII, I904, pp. I77-I92.

I904b. Oberholser, H. C. A Review of the Wrens of the Genus Troglodytes. $<$ Proc. U. S. Nation. Mus., XXVII, I904, pp. 197-210, pl. V.

I904. Ridgway, R. 'The Birds of North and Middle America. = U. S. Nation. Mus. Bull., no. 50. part 3, pp. i-xx, I-90I, pls. i-xix.

Ig04a. Swarth, H. S. The Status of the Southern California Cactus Wren. $<$ Condor, VI, I904, pp. I7-I9.

1904b. Swarth, H. S. Birds of the Huachuca Mountains, Arizona. = Pac. Coast Avifauna no 4, I904, pp. I-70.

One hundred and ninety-six species listed.

I905a. Breninger, G. F. Are the Habits of Birds Changing? < Auk, XXII, Ig05. pp. 360-363.

Running account of some unusual nesting sites used by several species in southern Arizona.

I905b. Breninger, G. F. The Yellow-billed Tropic Bird near Phoenix, Arizona. $<$ Auk, XXII, 1905, p. 408.

One specimen taken alive near Phoenix, in April, 1905, and recorded as Phaethon amcricanus. It eventually proved to be P. aethereus (see Miller, 1910). 
I905c. Breninger, G. F. The English Sparrow at Tucson, Arizona. < Auk, XXII, I905, p. 417 .

First recorded appearance of the species in the state.

1905. [Childs, I. L.] Eggs of the Olive Warbler (Dendroica olivacea) $<$ The Warbler, I, I905, p. I7, I col. pl., I fig.

Brief account of a set from the Huachuca Mountains, with a colored plate show ing the eggs, and figure of a pair of birds with nest.

1905. Oberholser, H. C. The Forms of Vermivora celata (Say). < Auk, XXII, 1905, pp. 242-247.

Vermivora celata orestera, new subspecies, described from. Willis, New Mexico, is mentioned as occurring at various points in Arizona; breeding at Mount Graham.

1905. Stone, W. On a Collection of Birds and Mammals from the Colorado Delta, Lower California. With Field Notes by Samuel N. Rhoads. < Proc. Acad. Nat. Sci. Phila., I905, pp. 676-690.

Includes observations made in the vicinity of Yuma.

I905a. Swarth, H. S. Summer Birds of the Papago Indian Reservation and of the Santa Rita Mountains, Arizona. < Condor, VII, I905, pp. 22-28, 4750, $77-8 \mathrm{I}$.

Giving separate annotated lists of sixty-four and sixty-nine species, respectively, for the two localities.

1905b. Swarth, H. S. A Correction. < Condor, VII, I905, p. 144.

I905c. Swarth, H. S. Atratus versus Megalonyx. < Condor, VII, I905, pp. I7 I-I 74, map.

A discussion of the races of Pipilo maculatus occurring in the southwestern United States, with description of a new subspecies, Pipilo maculatus montanus, the type from the Huachuca Mountains, Arizona.

I905. Willard, F. C. Notes from Cochise Co., Ariz.: Purple Gallinule. < Condor, VII, 1905, p. II2.

Account of the capture of a specimen of the Purple Gallinulc (Ionornis martinica) at Tombstone, Arizona, in June, 1904, with mention of an alleged occurrence of the same species in the Dragoon Mountains, in April, 1903.

I906. Bishop, L. B. Uranomitra salvini in Arizona. < Auk, XXIII, I906, pp. $337-338$.

A young female, the second known example of the species, taken at Palmerlee, Hnachuca Mountains, Arizona, on July 4, 1905.

I906. Brown, H. The Water Turkey and Tree Ducks near Tucson, Arizona. $<$ Auk, XXIII, Ig06, pp. 217-218.

Anhinga anhinga, Dendrocygna autumualis, and $D$. fulva, in parts of southern Arizona.

I906. [Childs, J. L.] Nest and Eggs of the Blue-throated Hummingbiri (Coeligena clemenciae). < The Warbler; II, 1906, p. 65, I col. pl.

From the Huachuca Mountains.

1906. Howard, O. W. The English Sparrow in the Southwest. < Condor, VIII, I906, pp. 67-68. 
Igo6. Miller, W. De W. List of Birds Collected in Northwestern Durango, Mexico, by J. H. Batty, during I903. < Bull. Amer. Mus. Nat. Hist., XXII, Igo6, pp. I6I-183.

Contains critical comments upon several Arizona species.

1906. Oberholser, H. C. The North American Eagles and their Economic Relations. = U. S. Dept. Agric., Biol. Surv., Bull. No. 27, pp. I-3I, 2 pls., 2 figs.

1906a. Ridgway, R. "Atratus versus Megalonyx". < Condor, VIII, I906, p. 53 .

Critical: Pipilo maculatus montanus Swarth considered a synonym of $P$. m. megalonyx Baird.

Igo6b. Ridgway, R. "Atratus versus Megalonyx". < Condor, VIII, Igo6, p. 100 .

Critical: Recognizing the validity of Pipilo maculatus montanus Swarth.

1907. Ridgway, R. The Birds of North and Middle America. = U. S. Nation. Mus. Bull., no. 5o, part 4, pp. i-xxii, I-973, pls. i-xxxiv.

1907a. Smith, A. P. The Thick-billed Parrot in Arizona. < Condor, IX, I907, p. 104 .

Account of the appearance of a flock of "700 to 1000 " in the Chiricahua Mountains, Arizona, in August, 1904.

Ig07b. Smith, A. P. Summer Notes from an Arizona Camp. < Condor, IX, I g07, pp. I96-r97.

A running account of some twenty-four species of birds observed in the. Whetstone Mountains, from May to August.

Igo8. Grinncll, J. The Name of the California Least Vireo. < Auk, XXV, I go8, pp. $85-86$.

1908. Henderson, J. The Monntain Bluebird in Northern Arizona. < Condor, $\mathrm{X}, 1908$, p. 94.

Jgo8. Hollister, N. Birds of the Region about Needles, California. < Auk, XXV, igo8, pp. 455-462.

References to several species seen on the Arizona side of the Colorado River at Fort Mohave.

1908a. Smith, A. P. Is the Mountain Bluebird Resident at High Altitudes? $<$ Condor, X, I908, p. 50 .

Sialia currucoides at Flagstaff, Arizona, during February and March, 1907.

1908b. Smith, A. P. Some Data and Records from the Whetstone Mountains, Arizona. < Condor, X, I908, pp. 75-78.

A running account of some of the species of birds observed in the region during the summer months.

1908c. Smith, A. P. Brain Parasite in White-necked Raven. < Condor, X, I 908 , p. 92.

I908d. Smith, A. P. Albinism of Scaled Partridge. < Condor, X, I908, p. 93. Two albino specimens of Callipepla squamata from the San Pedro Valley, Arizona. 
1908. Swarth, H. S. Some Fall Migration Notes from Arizona. < Condor, X. I908, pp. 107-I I6.

Annotated list of species of birds seen in the Rincon and Huachuca Mountains, Arizona, from September 21 to November 8, 1907.

rgo8. Wetmore, A. Notes on Some Northern Arizona Birds. < Kansas Univ. Sci. Bull., IV (whole series, XIV), I908, pp. 377-388.

An annotated list of forty species, observed at Willianns, Arizona, and on Bill Wiliams Mountain, February 24 to April 1, 1907. Specimens of Sturnclla magna hoopesi secured on the Coconino plains.

1908a. Willard, F. C. An Arizona Nest Census. < Condor, X, igo8, pp. 44-45. Running account of the species of bircis found breeding in a garden in Tombstone, Arizona.

I908b. Willard, F. C. Huachuca Notes. < Condor, X, Igo8, pp. 206-207.

I908c. Willard, F. C. Three Vireos: Nesting Notes from the Huachuca Mountains. < Condor, X, I908, pp. 230-234, 3 figs.

Lanivirco solitarius plumbeus, Virco huttoni stephensi, and Vircosylva gilva swainsoni; probably the southernmost breeding record of the last mentioned species.

I909a. Gilman, M. F. Among the Thrashers in Arizona. < Condor, XI, I909, pp. 49-54, I fig.

Observations on five species found on the Pina Indian Reservation, southern Arizona.

Igogb. Gilman, M. F. Some Owls Along the Gila River in Arizona. '<Condor, XI, Igog, pp. '145-I 50, 5 figs.

Six species treated: Bubo v. pallesccns, Aluco pratincola, Otus trichopsis ( = Otus asio gilmani), Speotyto c. hypogaca, Glancidium phaloenoides, and Micropallas whitricyi.

Igonc. Gi!man, M. F. Nesting Notes on the Lucy Warbler. < Condor, XI, I909, рр. I66-I68.

Inogd. Gilman, M. F. Red-eyed Cowbird at Sacaton, Arizona. < Conclor, XI, I909, p. I73.

1909. Grinnell, J. Three New Song Sparrows from California. < Univ. Calif. Publ. Zool., V, I909, pp. 265-269.

Contains the original description of Mclospiza mclodia saltonis, the breeding song sparrow of the lower Colorado River valley, here considered a different form from $M$. m. fallax Baird.

1909. Swarth, H. S. Distribution and Molt of the Mearns Quail. < Condor, XI, rgog, pp. 39-43, 4 figs.

I909. Visher, S. S. The Capture of the Red-eyed Cowbird in Arizona. < Auk, XXVI, I909, p. 307.

Near Tucson.

rgoga. Willard, F. C. Behavior of a Young Rivoli Hummingbird. < Condor, $\mathrm{XI}, 1909$, pp. IO2-IO3.

1909b. Willard, F. C. Nesting of the Arizona Junco. < Condor, XI, I909, pp. 129-13I, I fig.

In the Huachuca Mountains. 
Igogc. Willard, F. C. The Flammulated Screech Owl. < Condlor, XI, rgog, pp. 199-202, 5 figs.

Breeding in the Huachuca Mountains.

1910. American Ornithologists' Union. Check-List of North American Birds. Third Edition (Revised). New York, igı. Pp. I-430, 2 pls. (maps).

1910. Cooke, IV. W. Distribution and Migration of North American Shorebirds, = U. S. Dept. Agric., Biol. Surv., Bull. No. 35, I910, pp. I-100, pls. I-IV.

Pisobia minutilla and Numcnius americanus recorded for the first time as winter visitants in Arizona.

19ı. Gilman, M. F. Notes from Sacaton, Arizona. < Condor, XII, I9ro, pp. $45-46$.

19I0. McGee, W. J. Notes on the Passenger Pigeon. < Science, n. s. XXXII, I910, pp. 958-964.

The writer claims to have found Passenger Pigeons in abundance at Tinajas Altas, in the Gila Mountains, some seventy-five miles southeast of Yuma, in 1894, 1895, 1900, and 1905 . Undoubtedly a misidentification.

19ı. Miller, W. De W. The Red-billed Tropic-bird in Arizona. < Auk, XXV1I, I9IO, pp. 450, 45 I.

Correction of a previous erroneous record of Phacthon americanus (see Breninger, 1905b).

19ic. Nelson, E. W. A New Subspecies of Pigmy Owl. < Proc. Biol. Soc. Wash., XXIII, i9ıо, pp. Iо3-I04.

Gluucidium gnoma pinicola, from the "Rocky Mountain region of the United States and the Sierra Madre of northwestern Mexico," the type from Alma, New Mexico. Specimens from Arizona mentioned.

I9IOa. Swarth, H. S. Two New Owls from Arizona, with description of the juvenal plumage of Stri.t occidentalis occidcntalis (Xantus). < Univ. Calif. Publ. Zool., VII, pp. I-8.

Otus asio gilmani, type locality Blackwater, Pinal County, and Strix occidentalis huuchucae, type locality Huachuca .Mountains.

I9 Iob. Swarth, H. S. Miscellaneous Records from Southern California and Arizona. < Condor, XII, I910, pp. 107-IIO.

I9roa. Visher, S. S. A Correction: A New Bird for the United States. < Auk, XXVII, igio, p. 2 I0.

The Red-eyed Cowbird recorded from Tucson proves to be Tangavius acncus acneus, and not $T$. a. involucratus, as previously stated.

19rob. Visher, S. S. Notes on the Birds of Pima County, Arizona. < Auk, XXVII, I9I0, pp. 279-288.

One hundred and twenty-seven species listed, including several not otherwise known to occur in the state. Many of them are unquestionably misidentifications, and the paper contains hesides so many obvious mistakes and absurd statements that the records containcd in it must perforce be óisregarded. 
1910a. Willard, F. C. Nesting of the Western Evening Grosbeak (Hesperiphona vespertina montana). < Condor, XII, I910, pp. 60-62, I fig.

In the Huachuca Mountains, Arizona.

I9Iob. Willard, F. C. The Olive Warbler (Dendrica olizacea) in Southern Arizona. < Condor, XII, I910, pp. ro4-107, I fig.

I9roc. Willard, F. C. Seen on a Day's Outing in Southern Arizona. < Condor, XII, I9Io, p. I io.

Records the capture of the Texas Kingfisher (Ceryle amcricana septentrionalis) on the San Pedro River.

19i Ia. Gilman, M. F. Notes from Sacaton, Arizona. < Condor, XIIl, I91 I. p. 35 .

19r rb. Gilman, M. F. Doves on the Pima Reservation. < Condor, XIII, I9II. pp. $5 \mathrm{I}-56$.

Zcnaidura m. carolinensis, Melopelia asintica, Chacmepelia $p$. pallescens, and Scarda. fella inca, as observed at Sacaton, Arizona.

191. G. Grinnell, I. Description of a New Spotted Towhee from the Great Basin. $<$ Univ. Calif. Publ. Zcol., VII, I91 I, pp. 309-3II.

Pipilo maculatus curtatus, type locality Pine Forest Mountains, Nevada. Specimens taken in the lower Colcrado Valley in winter.

I9I Ia. Oberholser. H. C. A Revision of the Forms of the Hairy Woodpecker (Dryobates villosıs [Linnaeıs]). < Proc. U. S. Nation. Mus., XL. Igт. pp. 595-621.

Dryobates villosus leucothorectis and Dryobates villosus icastus, new forms described, ascribed to northern and southern Arizona, respectively.

I9IIb. Oberholser, H. C. A Revision of the Forms of the Ladder-backed Woodpecker (Dryobates scalaris [Wagler]). < Proc. U. S. Nation. Mus., XLI, I9I I, pp. I39-I 59, I pl. [map].

Contains the original description of Dryobates scalaris cactophilus, type locality Tucson, Arizona.

ı.gı ıa. Ridgway, R. Diagnoses of Some New Forms of Picidae. < Proc. Biol. Soc. Wash., XXIV, i911, pp. 3i-36.

Contains the origitial description of Colaptes chrysoides mearnsi, type locality Quitovaquito, Arizona.

I9I Ib. Ridgway, R. The Birds of North and Middle America. = U. S. Nation. Mus. Bull., no. 50, part 5, pp. i-xxiii, I-859, pls. i-xxxiii.

I9I I. Willard, F. C. The Blue-throated Hummingbird. < Condor, XIII, I9I I, pp. 46-49, 4 figs.

Breeding in the Huachuca Mountains.

1912a. Oberholser, H. C. A Revision of the Subspecies of the Green Heron (Butorides virescens [Linnaeus]). < Proc. U. S. Nation. Mus., XLII, I9I2. pp. 529-577.

I912b. Oberholser, H. C. A Revision of the Forms of the Great Blue Heron (Ardea herodias Linnaeus). < Proc. U. S. Nation. Mus., XLIII, I9I2, pp. 53 I -559 . 
1912. Sloanaker, J. L. Two New Arizona Records. < Condor, XIV, 1912, p. I 54 .

Grus canadensis and Clangula clangula amcricana from the vicinity of Tucson.

1912. Swarth, H. S. Report on a collection of birds and mammals from Van. couver Island. < Univ. Calif. Publ. Zool., X, pp. I-I 24, pls. I-4.

Critical remarks on the subspecies of Geothlypis trichas occurring in Arizona.

191 2a. Willard, F. C. A Week Afield in Southern Arizona. < Condor, XIV, I912,-pp. $53-63,7$ figs.

Running account of birds seen on an altomobile trip from the Huachuca Mountains to Tucson, and then to Tombstone.

1912b. Willard, F. C. Migration of White-necked Ravens. < Condor, XIV, I912, pp. 107-108.

In Cochise County, in November.

I9r2c. Willard, F. C. Breeding of the Scott Sparrow. < Condor, XIV, I9r2, pp. I95-I96, I fig.

In the Huachuca Mountains, Arizona.

19r2d. Willard, F. C. Nesting of the Rocky Mountain Nuthatch. < Condor. XIV, I9I2, pp. 2I3-2I5, 2 figs.

In the Huachuca Mountains, Arizona.

1913. Cooke, W. W. Distribution and Migration of North American Herons and their Allies. = U. S. Dept. Agric., Biol. Surv., Bull. No. 45, I9I3, pp. I-70, 2 I figs. (distribution maps).

Contains statements of the manner of occurrence of several species in Arizona.

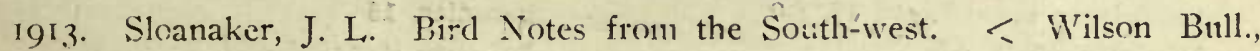
$\mathrm{XXV}$, I9I3, pp. I87-I99.

In the vicinity of Tucson.

19I3. Swarth, H. S. The Status of Lloyd's Bush-tit as a Bird of Arizona. $\because$ A11k, XXX, I9I3, pp. 399-401.

Critical. Arizona records of Psaltriparus $m$. lloydi shown to pertain to a juvenal plumage of $P$. plumbeus.

1913. Todi, W. F. C. A Revision of the Genus Chacmepelia. < Annals of the Carnegie Museum, VIII, I9I3. pp. 507-603.

References to Arizona specimens of Chaemepelia passerina pallescens.

1913a. Willard, F. C. Sonue Late Nesting Notes from the Huachuca Mountains, Arizona. < Conclor, XV, I9I3. p. $4^{\mathrm{I}}$.

Breeding of Toxostoma c. palmeri, Cyanolaemus clemcaciae, and Columba $f$. fasciata.

1913b. Willard, F. C. Late Nesting of Certain Birds in Arizoila. < Condor, $\mathrm{XV}, 1913$, p. 227.

Seven species treated, from the Huachuca Mountains.

19!3c. Willard, F. C. Sharp-shinned Hawk Nesting in Arizona. < Condor, $\mathrm{XV}$, I9I3, p. 229.

In the Huachuca Mountains. 


\section{INDEX}

\section{A}

Acanthylis pelasgia, 36 saxatalis, 37

Accipiter atricapillus, 25

atricapillus striatulus, 25

cooperi, 24,85

fuscus, 24

mexicanus, 24

velox, 24,85

velox pacificus, 24

velox rufilatus, 24

Actitis macularius, 20, 85

Actiturus bartramlus, 20

Actodromas baird1, 19 minutilla, 19

Aechmophorus occidentalis, 9, 88

Egialitis montanus, 21 semipalmata, 21,89 vociferus, 21

Aeronautes melanoleucus, 37,86

Agelaius gubernator, 47 gubernator californicus, 84 phoeniceus, 47 phoeniceus californicus, 84 phoeniceus fortis, 47,88 phoeniceus longirostris, 47 phoeniceus neutralis, 47,86 phoeniceus sonoriensis, 47,86 xanthocephalus, 47

Aimophila carpalis, 57, 86, 91, 100 ruficeps scotti, 57, 86, 87, 92, 94, 103

Aluco flammeus pratincoia, 29 pratincola, $29,86,116$

Ammodramus bairdi, 52, 88 passerinus, 53 sandwichensis alaudinus, 52 savannarum bimaculatus, 53,86 savannarum perpallidus, 53

Ammodromus savannarum, 53

Ampelis cedrorum, 64 garrulus, 64

Amphispiza belli clnerea, 56 belll nevadensis, 56

bllineata, 56

bilineata deserticola, 56, 86, 91, 109 nevadensis nevadensis, 56,88

Anas americana, 12 boschas, 11 carolinensis, 12 cyanoptera, 12 discors, 12 penelope, 12 . platyrhynchos, 11,85 strepera, 12
Anhinga, 10

Anhlnga anhinga, 10, 90, 114

Ani, Groove-billed, 32, 106

Anser albifrons, 14 albifrons gambeli, 14, 88 gambeli, 14 hyperboreus, 14

Anthus ludovicianus, 72 pensilvanicus, 72 rubescens, 72,88

Antrostomus nuttalli, 36 vociferus, 36 vociferus arizonae, 36 vociferus macromystax, $36,87,92$

Aphelocoma florldana woodhousel, 45 sieberi arizonae, 45, 86, 87, 92, 103 sordida arizonae, 45 woodhousei, $45,86,87,92$

Aquila canadensis, 27 chrysaetos, 27, 85, 92 chrysaetus canadensis, 27

Archibuteo ferrugineus, 26,88 lagopus, 26 lagopus sancti-johannis, 26, 90

Archilochus alexandri, 37, 87

Ardea candidissima, 16 egretta, 16 herodias, 16 herodias treganzai, 16,85 virescens, 16 virescens anthonyi, 16, 108

Ardetta exllis, 16

Asio accipitrinus, 29 americanus, 29 flammeus, 29,88 magellanicus pacificus, 30 magelianicus pallescens, 30 wilsonianus, 29,88

Astragalinus lawrencei, 51,88 psaltria, 51 psaltria arizonae, 51 psaltria hesperophilus, 51,86 tristis pallidus, 50,86

Astur atricapillus atricapillus, 25, 90

Asturina nitida, 26 nitida plagiata, 26,100 plagiata, $26,87,90,100$

Asyndesmus lewisi, 35,86 torquatus, 35

Athene cunicularia, 31 hypugaea, 31 whitneyi, 31, 96

Atlapetes chlorurus, 59 
Atthis costae, 37

heloisa morcomi, 39,90

morcomi, 39, 109

Auriparus flaviceps flaviceps, $78,86,87,91$

Avocet, American, 18

Aythya affinis, 13

americana, 13

marila nearctica, 13

vallisneria, 13

Baeolophus inornatus griseus, $77,86,92,94$ wollweberi, 77, 86, 87, 92, 103

wollweberi annexus, 77

Balanosphyra formicivora aculeata, 34

Baldpate, 12

Bartramia longicauda, 20, 90

Basilinna leucotis, 39, 87, 108, 112

Becard, Xantus, 40, 104

Bernicia brenta, 82

- canadensis, 14

hutchinsi, 14

Bittern, American, 15

Least, 16

Blackbird, Bicolored Red-winged, 84

Brewer, 49

Northern Red-winged, 47

San Diego Red-winged, 47

Sonora Red-winged, 47

Yellow-headed, 47

Bluebird, Azure, 81

Chestnut-backed, 81

Mountain, 81, 115

Bob-white, Masked, 21, 113

Bombycilla cedrorum, 64,88 garrula, 64,90

Botaurus lentiginosus, 15, 85 minor, 15

Brachyotus cassinii, 29

Brant, 82

Branta bernicla glaucogastra, 82 canadensis canadensis, 14,88 canadensis hutchinsi, 14,88

Bubo magellanicus, 30 magellanicus pallescens, 30

virginianus, 30

virginianus arcticus, 30

virginianus pacificus, 30

virginianus pallescens, $30,86,87,116$

virginianus saturatus, 30

virginianus subarcticus, 30

Bucephala albeola, 13

Buffle-head, 13

Bunting, Beautiful, 61

Lark, 61

Lazuli, 61

Painted, 61
Bush-tit, Lead-colored, 78

Lloyd, 119

Buteo abbreviatus, 25, 85, 102

albicaudatus sennetti, 26, 87, 90, 109

bairdi, 26

borealis, 25

borealis calurus, $25,85,87$

calurus, 25

elegans, 84

insignatus, 26,96

lineatus elegans, 84

montanus, 25

oxypterus, 26,96

swainsoni, $26,87,90,96$

zonocercus, 25

Butorides virescens, 16

virescens anthonyi, 16,85

\section{C}

Calamospiza bicolor, 61 meianocorys, 61,88

Calcarius ornatus, 51, 88, 104

Callipepla gambeli, 22 squamata squamata, $21,85,87,91,109$, 115

Calothorax lucifer, 39, 90, 98

Calypte anna, 38,90 costae, $37,86,91$

Camptostoma imberbe, 44, 87, 90

Campylorhynchus brunneicapillus, 74

Canace obscurus, 22

Canvas-back, 13, 106

Caprimulgus nuttallii, 36

Caracara, Audubon, 28

Cardellina rubrifrons, 72, 88, 93, 94, 104

Cardinal, Arizona, 60

Cardinalis cardinalis superbus, $60,86,91$, 101

igneus, 60

superbus, 60 .

virginianus, 60

virginianus igneus, 60

Carpodacus cailfornicus, 50

cassini, 50, 86, 92, 95

familiaris, 50

frontalis, 50

mexicanus frontalis, 50,86

mexicanus obscurus, 50

pileatus, 50

purpureus, 50

purpureus californicus, 49,90

Cathartes aura, 24

aura septentrionalis, 24,85

californianus, 83 
Catherpes mexicanus, 74

mexicanus conspersus, $74,86,87$

mexicanus polioptilus, 74

mexicanus punctulatus, 74

Catoptrophorus semipalmatus inornatus, 20 , 90

Celeus torquatus, 35

Centronyx bairdi, 52, 98

Centurus uropygialis, $35,86,87,91,95$

Certhia americana, 76

familiaris, 76

familiaris albescens, 76, 88, 93

familiaris americana, 76

familiaris mexicana, 76

familiaris montana, $76,82,92,100$

Certhioia flaveola, 96

Ceryle alcyon alcyon, 32,88

americana, 33

americana septentrionalis, $33,90,118$

Chaemepelia passerina pallescens, 23,85 , $91,118,119$

Chaetura vauxi, 36,89

Chamaepelia passerina, 23

Charadrius dominicus dominicus, 83 vociferus, 21

Charitonetta albeola, 13, 88

Chat, Long-talled, 71

Chaulelasmus streperus, 12, 85

Chelidon erythrogaster, 63

Chen hyperboreus hyperboreus, 14, 88

Chickadee, Mexican, 77

Mountain, 77

Chondestes grammaca, 53

grammacus strigatus, 53, 86

Chordeiles acutipennis texensis, 36, 87, 90 henryi, 36

popetue, 36

popetue henryi, 36

texensis, 36

virginianus, 36

virginianus henryi, 36, 87, 92

Chroecocephalus atricilla, 82

franklini, 82

Chroicocephalus philadelphia, 10

Chrysomitris lawrencei, 51

mexicana, 51

mexicanus arizonae, 51

pinus, 51

psaltria, 51

psaltria arizonae, 51

tristis, 50

Cichlopsis nitens, 64

Cinclus mexicanus, 72

mexicanus unicolor, 72,86

Circe latirostris, 39
Circus cyaneus, 24

cyaneus hudsonius, 24

hudsonius, 24,85

Cistothorus palustris, 75

palustris paludicola, 75

palustris plesius, 75

Clangula albeola, 13

clangula americana, 13, 90, 119

Ciivicola riparia, 63

Coccothraustes vespertina, 49, 104 vespertina montana, 49

Coccyzus americanus, 32 americanus occidentalis, 32,87

Coeligena clemenciae, 37, 109, 112

Colaptes auratus mexicanus, 35

ayresii, 35

cafer, 35, 109

cafer collaris, 35, 86, 102

chrysoides, 35, 109

chrysoides mearnsi, $35,86,87,91,102$, 118

mexicanus, 35

rubricatus, 35

Colinus ridgwayi, 21, 85, 87, 91, 101, 102, 103, 104, 113

Collurio borealis, 65 excubitoroides, 65

ludovicianus excubitorides, 65

Collyrio borealis, 65 excubitorides, 65

Columba fasciata fasciata, $23,85,92,112$, 119

flavirostris, 83

leucoptera, 23

Coiumbigallina passerina, 23

Colymbus arcticus pacificus, 82

auritus, 81

nigricollis californicus, 9,87

pacificus, 82

torquatus, 9

Condor, California, 83

Contopus borealis, 42

pertinax, 42, 106

pertinax pallidiventris, 42

richardsoni, 42

veliei, 42

virens richardsoni, 42

Coot, American, 18

Cormorant, Farallon, 11

Corvus americanus, 46

brachyrhynchos hesperis, 46,86

cacalotl, 46

carnivorus, 46

corax, 46

corax carnivorus, 46 
Corvus corax sinuatus, 46,86 cryptoleucus, $46,86,91$ splendens, 46

Coturnicops noveboracensis, 17, 90

Coturniculus bairdi, 52 passerinus, 53 passerinus perpallidus, 53 savannarum bimaculatus, 53

Cotyle riparia, 63 serripennis, 64

Cowbird, Bronzed, 47 Dwarf, 47 Red-eyed, 116, 117

Crane, Little Brown, 17 Sandhill, 17

Craxirex harrisii, 25 unicinctus, 25

Creciscus jamaicensis, 83

Creeper, Mexican, 76 Rocky Mountain, 76

Crossbill, Mexican, 50

Crotophaga sulcirostris, $32,90,106$

Crow, Western, 46

Cryptoglaux acadica acadica, 29, 86, 92

Cuckoo, California, 32

Culicivora plumbea, 79,95

Curlew, Long-billed, 21

Curvirostra americana, 50

Cyanocephalus cyanocephalus, 46,86

Cyanocitta californica, 45

floridana woodhousei, 45

macrolopha, 45

sordida, 45

stelieri, 45

stelleri diademata, $45,86,87,92$

stelleri macrolopha, 45

ultramarina arizonae, 45

woodhouseii, 45

Cyanocorax californica, 45 stelleri, 45

Cyanolaemus clemenciae, 37, 87, 93, 119

Cyanospiza amoena, 61 ciris, 61

Cyanura macrolopha, 45 stelleri macrolopha, 45

Cygnus americanus, 15

Cynanthus latirostris, 39, 87, 91

Cypselus melanoleucus, 37,95

Cyrtonyx massena, 22

montezumae, 22

montezumae mearnsi, 22, $85,87,93,94$, 110,112

Dafila acuta, 13,85

Dendragapus obscurus obscurus, $22,85,87$, 92, 93
Dendrocopus arizonae, 33 harrisi, 33

Dendrocygna autumnalis, 14, 90, 114

bicolor, 15,88

fulva, 15,114

Dendroica aestiva, 68 aestiva brewsteri, 68,89 aestiva morcomi, 68 aestiva sonorana, $68,88,90$ auduboni auduboni, 69, 86, 92 auduboni nigrifrons, $69,88,93$ coronata, 69,90 graciae, $69,88,92,96,106$ nigrescens, $69,88,92$ nigrifrons, 69,111 occidentalis, 70,89 olivacea, $68,108,114,118$

townsendi, 70,89

virens, $70,90,113$

Dickcissel, 61

Dipper, American, 72

Doricha enicura, 39,98

Dove, Inca, 24, 108

Mexican Ground, 23, 105

Western Mourning, 23

White-winged, 23, 91

Dowitcher, Long-billed, 19

Dryobates arizonae, $33,86,87,92,94,102$, 112

pubescens gairdneri, 33

pubescens homorus, 33,86

pubescens oreoecus, 33

scalaris, 33

scalaris bairdi, 33

scalaris cactophilus, $33,86,87,91,118$

stricklandi, 33

villosus harrisi, 33

viliosus hyloscopus, 33

villosus icastus, 33,118

villosus leucothorectis, $33,86,87,92$, 118

Duck, Greater Scaup, 13

Lesser Scaup, 13

Ruddy, 14

\section{E}

Eagle, Bald, 27

Golden, 27, 106

Ectopistes carolinensis, 23

Egret, American, 16

Egretta candidissima candidissima, 16, 89

Elanus leucurus, 84

Empidonax difficilis difficilis, 42,87

flaviventris difficilis, 42

fulvifrons pygmaeus, 43, 87, 93

griseus, 43,89 
Empidonax, hammondi, 42,89

obscurus, 43, 99

pusillus, 42

pygmaeus, 43

trailili pusillus, 42

trailli trailli, 42, 87,90

wrighti, 43,89

Eremophila alpestris chrysolaema, 44 cornuta. 44

Ereunetes mauri, 20, 88

cccidentalis, 20

pusillus, 20

Erismatura jamaicensis, 14, 85 rubida, 14

Eudromias montanus, 21

Eugenes fulgens, 37, 87, 93, 98, 106, 110, 112

Euphagus cyanocephalus, 49,86

Euspiza americana, 61

\section{$F$}

Falcinellus ordii, 15

Falco aesalon, 28

anatum, 27

columbarius columbarius, 27,88

coiumbarius richardsoni, 28,90

communis anatum, 27

femoralis, 28

fusco-caerulescens, 28, 86, 91

lanarius polyagrus, 27

mexicanus, 27,86

nigriceps, 27

peregrinus anatum, 27,86

polyagrus, 27

richardsoni, 28

saker polyagrus, 27

sparverius deserticolus, 28, 107

sparverius phaloena, 28

sparverius sparverius, 28, 86, 101

Falcon, Aplomado, 28

Prairie, 27, 111

Finch, California Purple, 49

Cassin Purple, 50

House, 50

Flicker, Mearns Gilded, 35, 91

Red-shafted, 35

Flycatcher, Arizona Crested, 40, 91

Ash-throated, 41

Black-crested, 100

Beardless, 44

Buff-breasted, 43, 110, 111

Coues, 42, 108, 113

Gray, 43

Hammond, 42

Olivaceous, 41,110

Olive-sided, 42

Painted, 99
Flycatcher, Sulphur-bellied, 40, 110

Traill, 42

Vermilion, 43, 91, 97, 105

Western, 42

Wright, 43

Fringilla blandingiana, 59

frontalis, 50

Fulica americana, 18, 85

\section{G}

Gadwall, 12

Gallinago delicata, 19,88 wiisonii, 19

Gallinula galeata, 18, 85

Gallinule, Florida, 18 Purple, 17, 114

Gambetta melanoleuca, 20

Garzetta candidissima, 16

Gavia immer, 9,88 pacifica, 82 stellata, 9, 90

Geococcyx californianus, $32,86,87,91$ viaticus, 32

Geothlypis macgillivrayi, 70 philadelphia macgiilivrayi, 70 tolmiei, 70

trichas, 70,71

trichas occidentalis, $70,71,88$

trichas scirpicola, 71, 88, 119

Glaucidium ferrugineum, 31, 97

gnoma, 31, 100

gnoma pinicola, $31,86,92,117$

passerinum californicum, 31

phaloenoides, 31, 86, 91, 104, 116

Gnatcatcher, Plumbeous, 79, 91, 103

Western, 78

Godwit, Hudsonian, 83

Marbled, 83

Golden-eye, American, 13

Goldfinch, Green-backed, 51

Lawrence, 51

Pale, 50

Goniaphea coerulea, 60 melanocephala, 60

Goose, Canada, 14

Hutchins, 14

Lesser Snow, 14

White-fronted, 14

Goshawk, American, 25 Mexican, 26, 100, 107

Graculus diiophus, 11

Grebe, American Eared, 9

Horned, 81

Pied-billed, 9

Western, 9 
Grosbeak, Black-headed, 60

Rose-breasted, 60

Western Blue, 60

Western Evening, 49, 118

Grouse, Dusky, 22

Grus canadensis, 17, 88, 119

mexicana, 17,85

Guara rubra, 82, 109

Guiraca caerulea, 60 caerulea eurhyncha, 60 caerulea lazula, $60,88,90$ melanocephala, 60

Gull, Bonaparte, 10

Franklin, 82

Heermann, 82

Laughing, 82

Ring-billed, 9

Western, 82

Gymnogyps californianus, 83

Gymnokitta cyanocephala, 46

Gyparchus papa, 83

\section{H}

Habia melanocephala, 60

Haliaeetus leucocephalus leucocephalus, 27, 86

Harporhynchus bendirei, 73,98

cinereus bendirei, 73

crissalis, 74,97

curvirostris, 73

curvirostris palmeri, 73, 97, 106

lecontei, 74, 108

redivivus lecontei, 74

Hawk, American Rough-legged, 26

American Sparrow, 28

Band-tailed, 111

Cooper, 24

Duck, 27

Ferruginous Rough-legged, 26

Harris, 25

Marsh, 24

Mexican Black, 26

Pigeon, 27

Red-bellied, 84

Sennett White-tailed, 26, 109

Sharp-shinned, 24, 119

Swainson, 26

Western Red-tailed, 25

Zone-tailed, 25

Hedymeles meianocephalus, 60

Heleodytes brunneicapillus, 74

brunneicapillus anthonyi, 74, 111

brunneicapillus couesi, $74,86,87,91$

Helminthophaga celata, 67

luciae, 67, 96, 97

ruficapilla, 67

virginlae, 67
Helminthophila celata, 67

celata lutescens, 68

luciae, 67

rubricapilia gutturalis, 67

ruficapilla, 67

ruficapilla gutturalis, 67

virginiae, 67

Helodromas solitarius, 20 solitarius cinnamomeus, 20,89

Herodias alba egretta, 16 egretta, 16, 89

Heron, Anthony Green, 16 Black-crowned Night, 16

Pallid Great Blue, 16

Snowy, 16

Herse thalassina, 63

Hesperiphona vespertina, 49 vespertina montana, $49,86,92,118$

Himantopus mexicanus, 18, 89 nigricollis, 18

Hirundo bicolor, 63 erythrogastra, 63,88

horreorum, 63

lunifrons, 62

rufa, 63

thalassina, 63

Horizopus pertinax pallidiventris, 42 richardsoni, 42

Hummingbird, Allen, 38

Anna, 38

Black-chinned, 37

Blue-throated, 37, 109, 118

Broad-billed, 39

Brcad-tailed, 38

Calliope, 39

Costa, 37

Lucifer, 39

Morcom, 39

Rivoli, 37, 110, 116

Rufous, 38

Salvin, 39

White-eared, 39

Hydrobata mexicana, 72

Hydrochelidon fissipes, 10

lariformis, 10

nigra, 10

nigra surinamensis, 10,90

surinamensis, 10

Hylocichla fuscescens salicicola, 79, 90 guttata auduboni, $80,88,92,94$

guttata guttata, 80,88

guttata nanus, $80,88,89$

guttata slevini, 80,89

nana, 80

ustulata swainsoni, 79

ustulata ustulata, 79,89 
Hypotriorchis columbarius, 27 femoralis, 28

\section{I}

Iache latirostris, 39

Ibis, Scarlet, 82, 109

White-faced Glossy, 15

Wood, 15

lbis guarauna, 15

ordii, 15

thalassinus, 15

Icteria longicauda, 71

virens longicauda, 71,88

viridis, 71

Icterus bullocki, 49, 87

cucullatus, 49, 102

cucullatus nelsoni, 49, 87, 90, 101

parisorum, 48, 87, 91, 102

Ictinia mississipiensis, 96

Ionornis martinicus, $17,90,104,114$

Iridoprocne bicolor, 63,89

Ixobrychus exilis, 16, 90

Ix.oreus naevius naevius, 85

\section{J}

Jay, Arizona, 45

Long-crested, 45, 97

Pinon, 46

Rocky Mountain, 45

Woodhouse, 45

Junco, Arizona, 56, 105, 116

Gray-headed, 55

Montana, 55

Pink-sided, 55

Red-backed, 56

Shufeldt, 55

Sierra, 55

Slate-colored, 55

Junco annectens, 55

caniceps, $55,88,98$

cinereus, 56, 98, 102

cinereus caniceps, 55

cinereus dorsalis, 56

cinereus palliatus, 56

connectens, 55

dorsalis, 56, 98

hyemalis connectens, $\mathbf{5 5}$

hyemalis hyemalis, 55,88

hyemalis mearnsi, 55

hyemalis montanus, 55

hyemalis oregonus, 55

hyemalis thurberi, 55

mearnsi, 55,88

montanus, 55, 90

oregonus, 55

oreganus thurberi, $55,88,89$
Junco oreganus shufeldti, 55, 88

phaeonotus caniceps, 55

phaeonotus dorsalis, 56, 86, 87, 93, 98

phaeonotus pailiatus, $56,86,87,93,98$ ridgwayi, 55, 105

\section{K}

Killdeer, 21

Kingbird, Cassin, 40

Western, 40

Kingfisher, Belted, 32

Texas, 33, 118

Kinglet, Golden-crowned, 85

Ruby-crowned, 78

Kite, White-tailed, 84

Lanius borealis, 65,90

ludovicianus, 65

Iudovicianus excubitorides, 65,86

Lanivireo solitarius cassini, 65,89 solitarius plumbeus, $66,88,92,116$

Lark, Desert Horned, 44

Montezuma Horned, 44

Prairie Horned, 84

Scorched Horned, 44

Sonora Horned, 44

Larus atricilla, 82

delawarensis, 9,90

franklini, 82

heermanni, 82

occidentalis, 82

philadelphia, 10

Limonites minutilla, 19

Limosa fedoa, 83 haemastica, 83

Lobipes lobatus, 18, 90

Longspur, Chestnut-collared, 51, 104, 105 McCown, 52, 104, 105

Loon, Common, 9

Pacific, 82

Red-throated, 9

Lophodytes cucullatus, 11, 90

Lophophanes inornatus, 77 wollweberi, 77, 103

Lophortyx californicus, 22 gambeli, $22,85,87,91,96$

Loxia curvirostra americana, 50 curvirostra mexicana, 50 curvirostra stricklandi, 50, 86, 92

M

Macrorhamphus griseus, 19 griseus scolopaceus, 19,90

Magpie, 45

Mallard, 11 
Mareca americana, 12, 85

Marila affinis, 13,88 americana, 13,88 marila, 13,88 valisineria, 13,88

Martin, Purple, 62

Meadowlark, Texas, 48 Western, 48

Megascops asio cineraceus, 30 asio trichopsis, 30 aspersus, 30, 109 flammeolus, 30 trichopsis, 30,110

Meianerpes erythrocephalus, 34, 90

Melanerpes formicivorus, 34 formicivorus aculeatus, $34,86,92,94$, 105

formicivorus bairdi, 34

melanopogon, 34

torquatus, 35

uropygialis, 35

Meleagris gallopavo, 23, 110

gallopavo merriami, $23,85,87,93,110$, 111

mexicana, 23

Melopelia asiatica, 23, 118 asiatica trudeaui, $23,87,90$ leucoptera, 23

Melospiza cinerea fallax, 57 fallax, 57

fasciata fallax, 57

fasciata montana, 57 .

lincolni lincolni, 58, 88

melodia, 57

melodia fallax, 57, 88, 116

melodia heermanni, 57

melodia merrilli, 58, 90

melodia montana, 57

melodia saltonis, 57, 86, 87, 91, 116

Merganser, American, 11

Hooded, 11

Red-breasted, 11

Merganser americanus, 11 serrator, 11

Mergus americanus, 11, 85 serrator, 11,88

Merlin, Richardson, 28

Merula migratoria propinqua, 80

Micrathene whitneyi, 31, 98, 100

Micropallas whitneyi, $31,86,91,98,100,112$, 116

Micropus melanoleucus, 37

Mimus montanus, 72

polyglottus, 73

polyglottus caudatus, 73

polyglottos leucopterus, 73,86
Mitrephorus fulvifrons pallescens, 43 pallescens, 43

Mockingbird, Western, 73

Molothrus ater, 47

ater obscurus, $47,86,91$

obscurus, 47,99

pecoris, 47

pecoris obscurus, 47

Morphnus unicinctus, 25

Myadestes townsendi, 79, 86, 92

Mycteria americana, 15, 87

Myiarchus cinerascens cinerascens, 41,86 , 106, 113

cooperi, 40, 99

crinitus cinerascens, 41

lawrencei, 41, 99

lawrencei olivascens, 41, 87, 91, 99, 101

lawrencei olivaceus, 41

magister magister, 40, 87, 90, 99, 101

mexicanus, 41

mexicanus cooperi, 40

mexicanus magister, 40

nuttingi, 41, 106, 113

Myiochanes pertinax pallidiventris, 42,87 , 93

richardsoni richardsoni, $42,87,91$

Myiodioctes pileolatus, 71

pusillus, 71

pusillus pileolatus, 71

Myiodynastes luteiventris, 40,87, 93

\section{$\mathrm{N}$}

Nannus hiemalis pacificus, 75,90

Nauclerus furcatus, 96

Nettion carolinense, 12, 88

Nighthawk, Texas, 36,91

Western, 36

Nisus cooperi, 24 fuscus, 24

Nucifraga columbiana, 46, 86, 92

Numenius americanus, 21, 89, 117 longirostris, 21

Nuthatch, Red-breasted, 76 Pigmy, 77

Rocky Mountain, 76, 119

Nutcracker, Clarke, 46

Nuttallornis borealis, $42,87,92$

Nyctale acadica, 29

Nyctiardea gardeni, 16

grisea naevia, 16

Nycticorax nycticorax naevius, 16, 85

\section{0}

Olbiorchiius hiemalis pacificus, 75

Olor columbianus, 15,88

Oporornis tolmiei, 70,88 
Oreoscoptes montanus, 72,88

Oreospiza chlorura, 59, 88

Oriole, Arizona Hooded, 49

Bullock 49

Scott, 48

Ornithion imberbe ridgwayi, 44

Ortyx graysoni, 21, 101

ridgwayi, 21

virginianus, 21, 100, 101

Osprey, American, 28

Otocoris alpestris, 44

alpestris actia, 44

alpestris adusta, 44, 86, 87, 91, 105

alpestris aphrasta, 44

alpestris arenicola, 44

alpestris chrysolaema, 44

alpestris enthymia, 44

alpestris leucansiptila, 44, 112

alpestris leucolaema, 44, 88

aipestris occidentalis, 44,86

alpestris pallida, 44, 86, 87, 91

alpestris praticola, 84

Utocorys arenicola, 44

Otus americanus, 29

brachyotus, 29

asio cineraceus, $30,86,92$

asio gilmani, 30, 86, 91, 101, 116, 117

flammeolus, $30,87,93$

trichopsis, $30,87,93,109,116$

vulgaris wilsonianus, 29

wilsonianus, 29

Owi, American Barn, 29

American Long-eared, 29, 100

Arizona Spotted, 29

Burrowing, 31

California Pigmy, 100

Elf, 31, 91, 104

Ferruginous Pigmy, 31, 109

Flammulated Screech, 30, 117

Mexican Screech, 30

Rocky Mountain Pigmy, 31

Sahuaro Screech, 30, 91

Saw-whet, 29

Short-eared, 29

Spotted, 100

Spotted Screech, 30, 103, 110

Western Horned, 30

Whitney, 100

Oxyechus vociferus, 21,85

Pandion carolinensis, 28

haliaetus carolinensis, 28, 89

Panyptila melanoleuca, 37

Parabuteo unicinctus harrisi, 25, 85, 91

Paroides flaviceps, 78
Parrot, Thick-billed, 32, 115

Parus gambeli, 77

inornatus griseus, 77

inornatus ridgwayi, 77

meridionalis, 77,99

montanus, 77

wollweberi, 77

Passer domesticus, 50, 86, 87

P'asserculus alaudinus, 52 bairdi, 52

rostratus rostratus, 52,90

sandwichensis alaudinus, 52,88

sandwichensis nevadensis, 52, 86

savanna, 52

Passerella iliaca schistacea, 58, 88 townsendi schistacea, 58

Passerina amoena, 61, 88

ciris, 61,89

versicolor, 61

versicolor pulchra, 61,90

Pelecanus erythrorhynchos, 11, 88 trachyrhynchus, 11

Pelican, American White, 11

Pelidna alpina sakhalina, 19, 90

Penthestes gambeli gambeli, 77, 86, 92 sclateri, 77, 86, 93, 99

Perisoreus canadensis capitalis, 45, 86, 87, 92, 93

Petrochelidon lunifrons lunifrons, 62, 88 lunifrons melanogastra, 63, 88

lunifrons tachina, 62

melanogaster, 63,111

Peucaea aestivalis arizonae, 56

arizonae, 56

botterii, $56,88,90$

carpalis, $57,98,100$

cassinii, 56, 57, 88,90

homochlainys, 57

lincolni, 58

ruficeps boucardi, 57, 103

ruficeps scotti, 57, 104

Peucedramus olivaceus, $68,86,93,94$

Pewee, Western Wood, 42

Phaethon aethereus, 10, 90, 113 americanus, $10,113,117$

Phainopepla, 64

Phainopepla nitens, 64, 86, 91, 100, 102

Phalacrocorax auritus albociliatus, 11, 88

Phalaenoptilus nuttalii nitidus, 36, 103 nuttallii nuttallii, 36,86

Phalarope, Northern, 18 Wilson, 18

Phalaropus lobatus, 18 wilsoni, 18

Phoebe, Black, 41 Say, 41 
Pica caudata hudsonica, 45

hudsonica, 45

pica hudsonia, 45,90

Picicorvus columbianus, 46, 97

Picoides americanus dorsalis, 34, 86, 87, 92, 93

Picus arizonae, 33, 102

gairdneri, 33

harrisii, 33

pubescens, 33

pubescens gairdneri, 33

scalaris, 33

stricklandi, 33

varius, 34

villosus harrisi, 33

Pigeon, Band-tailed, 23

Passenger, 117

Red-billed, 83

Pintail, 13

Pipilo aberti, 59, 86, 87, 91, 105

arctica, 58

chlorura, 59

erythrophthalmus, 58

fuscus mesoleucus, 59, 86, 87, 94, 105

maculatus curtatus, $59,88,118$

maculatus megalonyx, 58

maculatus montanus, $58,86,87,92$, 114,115

megalonyx, 58

mesoleucus, 59,95

oregonus, 58

Pipit, American, 72

Piranga hepatica, 62, 88, 93

ludoviciana, $62,88,92$

rubra cooperi, $62,88,90$

Pisobia bairdi, 19,89 minutilla, 19, 88, 117

Planesticus migratorius, 80 migratorius propinquus, $80,86,92$

Platypsaris aglaiae albiventris, 40, 90 albiventris, 40, 104

Plectrophanes maccownii, 52 melanomus, 51 ornatus, 51

Plegadis autumnalis, 15 guarauna, 15,87

Plover, Golden, 83 Mountain, 21

Semipalmated, 21

Podasocys montanus, 21, 88

Podiceps auritus californicus, 9 californicus, 9 cornutus, 81 occidentalis, 9

Podilymbus carolinensis, 9 podiceps, 9,88
Poecile montanus, 77

Polioptila caerulea, 78 caerulea obscura, 78, 86, 92 caerulea plumbea, 79

melanura, 79, 99

plumbea, $79,86,87,91,99,103$

Polyborus audubonii, 28 cheriway, 28, 86, 91 tharus, 28 tharus auduboni, 28

Polytmus rufus, 38

Pooecetes gramineus, 52 gramineus confinis, 52,86

Poorwill, 36

Poospiza belli, 56 belli nevadensis, 56 bilineata, 56

Porzana carolina, 17, 85 jamaicensis, 83

Progne purpurea, 62 subis hesperia, 62 subis subis, 62,88

Protonotaria citrea, 67, 90

Psaltria plumbea, 78, 95

Psaltriparus melanotis lioydi, 78, 112, 119 minimus plumbeus, 78 plumbeus, 78, 86, 87, 104, 119 santaritae, 78, 104, 112

Pseudogryphus californianus, 83

Pterocyanea caeruleata, 12

Ptiliogonys nitens, 64

Pyranga aestiva, 62 aestiva cooperi, 62 azarae, 62 cooperi, 62 hepatica, 62 ludoviciana, 62

Pyrocephalus mexicanus, 43 rubineus, 43 rubinus mexicanus, $43,86,91,97$

Pyrrhuloxia, Arizona, 60

Pyrrhuloxia sinuata beckhami, 60 sinuata sinuata, $60,86,91$

Quail, Desert, 22

Fool, 22

Gambel, 108, 109

Mearns, 22, 116

Scaled, 21

Querquedula carolinensis, 12

cyanoptera, 12,85

discors, 12,85

Rail, Black, 83 
Rail, Light-footed, 17

Virginia, 17

Yellow, 17

Rallus levipes, 17, 90

virginianus, 17,88

Raven, American, 46

White-necked, 46, 112, 115, 119

Recurvirostra americana, 18, 88

Redhead, 13

Redstart, American, 71

Painted, 72, 111

Regulus calendula calendula, 78, 86, 92 satrapa olivaceus, 85

satrapa satrapa, 85

Rhinogryphus aura, 24

Rhyacophilus solitarius, 20

Rhynchophanes mccowni, 52, 88, 110

Rhynchopsitta pachyrhyncha, 32, 90, 110

Riparia riparia, 63,88

Roadrunner, 32

Robin, Western, 80

\section{S}

Salpinctes obsoletus obsoletus, $74,86,87$

Sandpiper, Baird, 19

Bartramian, 20

Least, 19

Spotted, 20

Red-backed, 19

Western, 20

Western Solitary, 20

Sapsucker, Red-naped, 34

Williamson, 34

Sarcoramphus papa, 83, 99 .

Sayornis nigricans, 41, 86 nigricans semiatra, 41 sayus, $41,86,91$

Scardafella inca, 24, 85, 91, 118

Sciurus tenuirostris, 70

Scolecophagus cyanocephalus, 49 ferrugineus, 49

Scolopax wilsonii, 19

Scops asio, 30

asio maccalli, 30

asio trichopsis, 30,101

flammeola, 30

mccalli, 30

trichopsis, 30

Seiurus noveboracensis, 70 noveboracensis notabilis, 70,89

Selasphorus alleni, 38, 90

costae, 37

platycercus, 38,87

rufus, 38,89

Setophaga picta, 72, 88, 93, 97, 99, 100 ruticilla, 71, 90

Shoveller, 12
Shrike, Northern, 65

White-rumped, 65

Sialia arctica, 81

currucoides, $81,86,92,115$

mexicana, 81

mexicana bairdi, $81,86,92,108$

mexicana occidentalis, 81

occidentalis, 81

sialis azurea, 81

sialis fulva, 81,88

Siskin, Pine, 51

Sitta aculeata, 76

canadensis, $76,86,92$

carolinensis, 76

carolinensis aculeata, 76

carolinensis nelsoni, 76, 86, 112

pusilla pygmaea, 77

pygmaea pygmaea, $77,86,87,92,94$

Siurus naevius, 70

Snipe, Wilson, 19

Solitaire, Townsend, 79

Sora, 17

Sparrow, Baird, 52

Black-chinned, 54

Botteri, 56

Brewer, 54

Cassin, 57

Clay-colored, 54

Desert, 56

Desert Song, 57

English, 50, 114

Intermediate, 53

Large-billed, 52

Lincoln, 58

Merrill Song, 58

Mountain Song, 57

Nevada Savannàh, 52

Rufous-winged, 57, 100

Sage, 56

Scott, 57, 119

Slate-colored Fox, 58

Western Chipping, 54

Western Grasshopper, 53

Western Lark, 53

Western Savannah, 52

Western Tree, 54

Western Vesper, 52

White-crowned, 53

Spatula clypeata, 12,85

Speotyto cunicularia hypogaea, $31,86,87$, 91, 116

Sphyrapicus nuchalis, 34

thyroideus, $34,86,92,96$

varius, 34

varius nuchalis, 34,88

williamsonii, 34,96 
Spinus lawrencei, 51 pinus, 51, 86, 92 psaltria, 51 psaltria arizonae, 51 tristis, 50 tristis pallidus, 50, 105

Spiza americana, 61,89 amoena, 61

Spizella atroguiaris, 54, .87 breweri, 54, 86 canadensis, 54 evura, 54 monticola, 54 monticola ochracea, 54, 90 pallida, 54, 89 pallida breweri, 54 passerina arizonae, 54, 86 pusio, 54 socialis, 54 socialis arizonae, 54, 97

Steganopus tricolor, 18, 89 wilsoni, 18

Stelgidopteryx serripennis, 64,88

Stellula calliope, 39,89

Sterna forsteri, 10, 90 hirundo, 10, 90

Stilt, Black-necked, 18

Strigiceps uliginosus, 29

Strix americana, 29

flammea, 29

flammea americana, 29

occidentalis, 29,117

occidentalis huachucae, $29,86,92,94$, 98,117

pratincola, 29

Struthus caniceps, 55, 56 oregonus, 55

Sturnella magna hoopesi, 48, 86, 116 magna mexicana, 48 magna neglecta, 48 neglecta, 48,86

Swallow, Bank, 63 Barn, 63, 109, 111 Cliff, 62, 111 Mexican Cliff, 63 Northern Violet-green, 63 Rough-winged, 64 Tree, 63

Swan, Whistling, 15

Swift, Vaux, 36 White-throated, 37

Sylvania pusilla, 71 pusilla pileolata, 71 audubonii, 69

Symphemia semipalmata, 20 Syrnium occidentale, 29, 98

\section{$\mathbf{T}$}

Tachycineta bicolor, 63

thalassina, 63

thalassina lepida, 63, 88, 92

Tanager, Cooper, 62

Hepatic, 62

Western, 62

Tangavius aeneus aeneus, 47, 87, 90, 117 aeneus involucratus, 47,117

Tantalus loculator, 15

Teal, Blue-winged, 12

Cinnamon, 12

Green-winged, 12

Telmatodytes palustris, 75 palustris plesius, 75,86

Tern, Black, 10

Common, 10

Forster, 10

Thrasher, Bendire, 73, 91, 105, 111

Brown, 73

Crissal, 74, 91, 96, 103

Leconte, 74, 91, 96, 103, 108

Palmer, 73, 91, 104, 105, 106

Sage, 72

Thrush, Dwarf Hermit, 80

Kadiak Hermit, 80

Monterey Hermit, 80

Rocky Mountain Hermit, 80

Russet-backed, 79

Varied, 85

Willow, 79

Thryomanes bewickii bairdi, 75 bewickii drymoecus, 75

bewicki eremophilus, $75,86,87$

bewicki 'leucogaster, 75

Thryothorus bewickii, 75

bewickii bairdi, 75

bewicki leucogaster, 75, 100

bewickii murinus, 75

mexicanus, 74

obsoletus, 74

Tinnunculus sparverius, 28

Titmouse, Bridled, 77

Gray, 77

Yellow-headed, 99

Totanus flavipes, 83

melanoleucus, 20, 89

semipalmatus, 20

solitarius, 20

Towhee, Abert, 59

Canyon, 59

Green-tailed, 59, 108

Mountain, 58

Nevada, 59 
Tóxcstoma bendirei, $73,86,87,91$

crissale, $74,86,87,91$

curvirostre palmeri, $73,86,87,91,119$

lecontei lecontei, $74,86,87,91$

rufum, 73,90

vetula, 73

Tree-duck, Black-bellied, 14

Fulvous, 15

Tringa alpina pacifica, 19

bairdi, 19

minutilla, 19

pusilla, 20

schinzii, 19

Tringoides bartramius, 20

macularius, 20

Trochilus alexandri, 37

alleni, 38

anna, 38

calliope, 39

costae, 37

platycercus, 38

rufus, 38

Troglodytes aedon, 75

aedon aztecus, 75

aedon marianae, 75

aedon parkmani, $75,86,92$

domesticus parkmani, 75

obsoletus, 74

parkmanni, 75

Trogon, Coppery-tailed, 32, 104

Trogon ambiguus, 32, 87, 93, 94, 104, 112

Tropic-bird, Red-billed, 10, 117

Yellow-billed, 113

Turdus aonalaschkae, 80

aonalaschkae auduboni, 80

fuscescens salicicolus, $79^{\circ}$

guttatus auduboni, 80

migratorius, 80

migratorius propinquus, 80

naevius, 85

nanus, 80

pallasi auduboni, 80

pallasi nanus, 80

unalascae, 80

unalascae auduboni, 80

ustulatus, 79

Turkey, Merriam, 23

Mexican, 110

Water, 114

Tyrannula saya, 41

Tyrannus verticalis, $40,87,90$ vociferans, $40,86,92$

\section{U}

Uranomitra salvini, $39,90,114$

Urinator lumme, 9
Urubitinga anthracina, 26, 85, 102, 112

Verdin, 78, 91, 99

Vermivora celata celata, 67,88

celata lutescens, 68,89

celata orestera, 67,114

luciae, $67,88,90$

rubricapilla gutturalis, 67,89

virginiae, $67,88,92$

Vireo, Arizona, 66

Cassin, 65

Gray, 66

Plumbeous, 66

Red-eyed, 65

Stephens, 66

Western Warbling, 65

Vireo bellii, 66

belli arizonae, $66,88,90$

belli pusillus, 66

gilvus, 65

gilvus swainsoni, 65

huttoni, 66

huttoni stephensi, 66, 86, 87, 92, 94, 116

olivaceus, 65

plumbeus, 66, 96

pusillus, 66

solitarius, 65

solitarius cassini, 65

solitarius plumbeus, 66

swainsoni, 65

vicinior, $66,88,91,96,102$

Vireosylva gilva swainsoni, $65,88,91,116$ olivacea, 65,90

Vireosylvia plumbea, 66 solitaria, 65

Vulture, California, 109

King, 83

Turkey, 24, 109

\section{W}

Warbler, Audubon, 69

Black-fronted, 69

Black-throated Gray, 69

Black-throated Green, 70

Calaveras, 67

California Yellow, 68

Golden Pileolated, 71

Grace, 69

Hermit, 70

Lucy, 67, 91, 116

Lutescent, 68

Macgillivray, 70

Myrtle, 69

Olive, $68,108,114,118$

Orange-crowned, 67 
Warbler, Pileolated, 71 Prothonotary, 67, 113 Red-faced, 72, 104 Sonora Yellow, 68, 91 Townsend, 70 Virginia, 67 Wilson, 84

Water-thrush, Alaska, 70

Waxwing, Bohemian, 64 Cedar, 64

Whip-poor-will, Stephens, 36, 111

Willet, Western, 20

Wilsonia pusilla chryseola, 71,89 pusilla pileolata, $71,88,92$ pusilla pusilla, 84

Woodpecker, Alpine Three-toed, 34 Arizona, 33

Batchelder, 33

Cactus, 33

Gila, 35

Lewis, 35, 111

Mearns, 34

Red-headed, 34

White-breasted, 33

White-headed, 84

Wren, Cactus, 74, 91, 106, 111

Canyon, 74

Desert, 75

Parkman, 75

Rock, 74

Western Marsh, 75
Wren, Western Winter, 75

White-bellied, 100

$\mathrm{x}$

Xanthocephalus icterocephalus, 47

longipes, 47

xanthocephalus, 47,86

Xenopicus albolarvatus, 84

$Y$

Yeliowlegs, 83

Greater, 20

Yellowthroat, Tule, 71

Western, 70

z

Zamelodia Iudoviciana, 60, 90 melanocephala melanocephala, $60,88,92$

Zenaidura carolinensis, 23 macroura, 23 macroura carolinensis, 23,118

macroura marginella, 23,85

Zonotrichia blandingiana, 59 cassini, 57

fallax, 57,95

gambelii, 53

graminea, 52

intermedia, 53

leucophrys, 53

leucophrys gambeli, 53, 88

leucophrys intermedia, 53

leucophrys leucophrys, 53, 87, 92, 93 



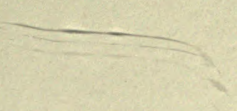




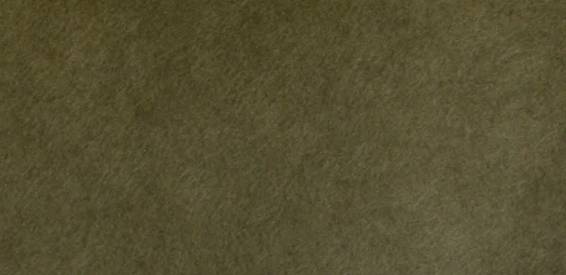

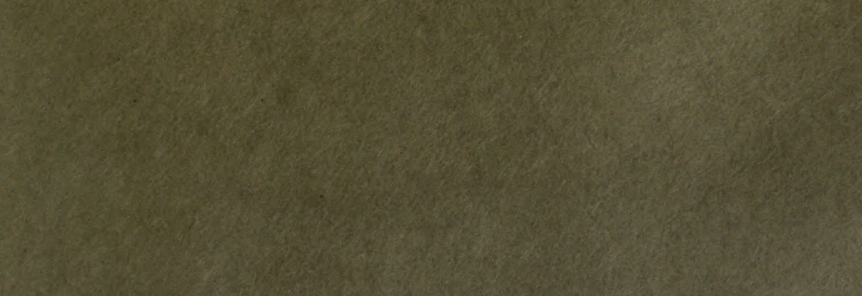

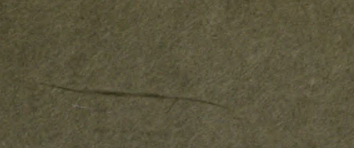


THIS BOOK IS DUE ON THE LAST DATE STAMPED BELOW

AN INITIAL FINE OF 25 CENTS WILL BE ASSESSED FOR FAILURE TO RETURN THIS BOOK ON THE DATE DUE. THE PENALTY WILL INCREASE TO 50 CENTS ON THE FOURTH DAY AND TO \$1.00 ON THE SEVENTH DAY OVERDUE.

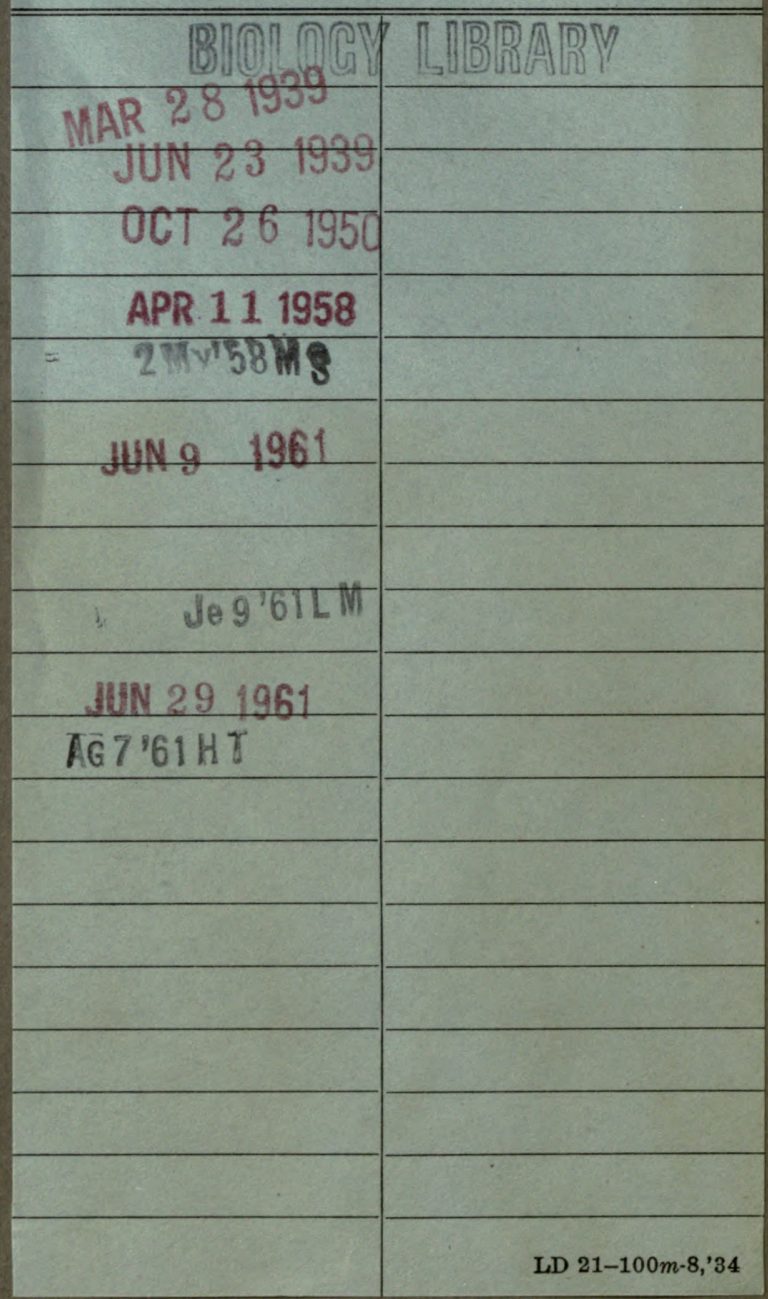




\section{6 \\ QL684 A 6583}

BIOLOGY

UIBRARY

THE UNIVERSITY OF CALIFORNIA LIBRARY 



$$
\begin{aligned}
& \text { Wut }
\end{aligned}
$$

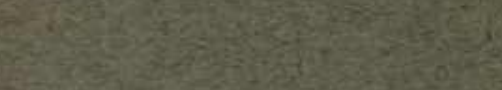

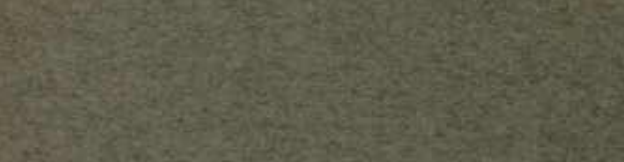

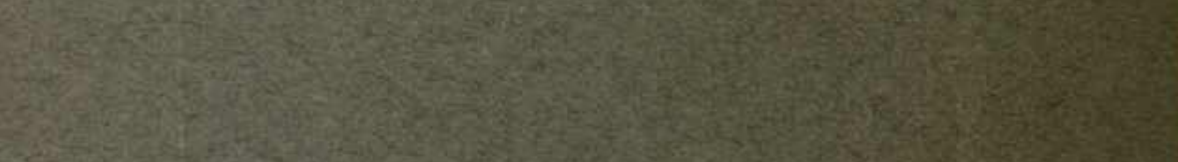

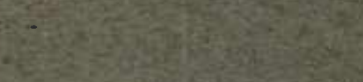

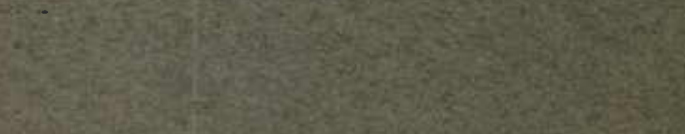

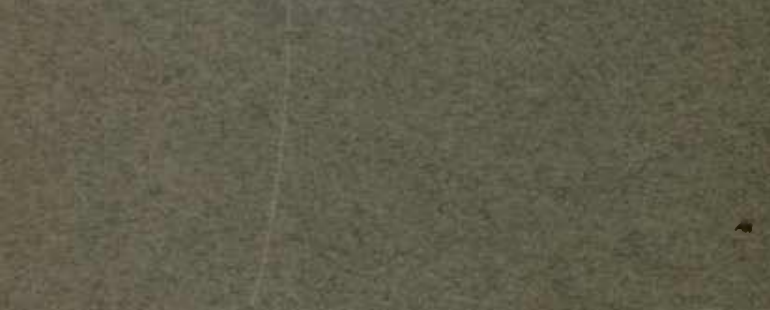

$$
\begin{aligned}
& \text { ations } \\
& \text { ifotitis }
\end{aligned}
$$

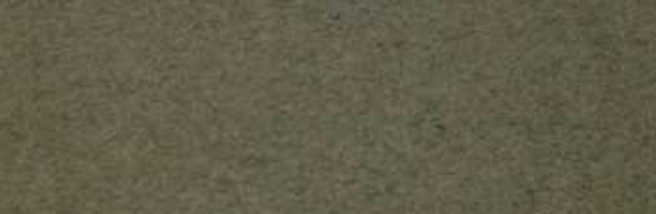

$$
\begin{aligned}
& \text { 5. }
\end{aligned}
$$

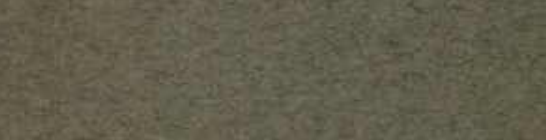

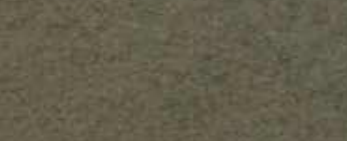

$$
\begin{aligned}
& 8 x^{2}
\end{aligned}
$$

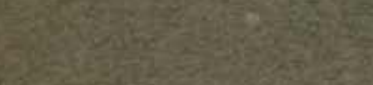

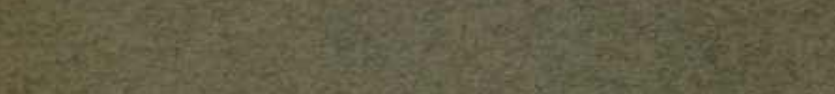

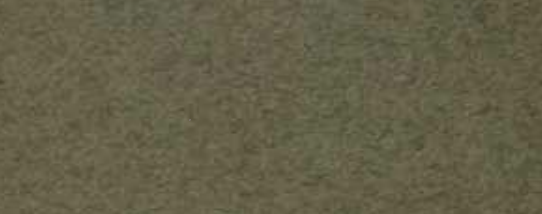

